\title{
Sobre los riesgos del tecnicismo jurídico en la moderna Teoría del Derecho
}

\author{
Alberto Montoro Ballesteros \\ Catedrático de Filosofía del Derecho \\ Universidad de Murcia
}

SUMARIO: I. LA PREOCUPACIÓN POR LA CIENTIFICIDAD DEL CONOCIMIENTO JURÍDICO. - II. LA CONCEPCIÓN DEL DERECHO COMO INSTRUMENTO TÉCNICO EN LAS TEORÍAS IDEOLÓGICO-POLÍTICAS. 1. Marxismo y teoría soviética del Derecho. A) Supuestos epistemológicos. a) El materialismo histórico. b) El materialismo dialéctico: $1^{\circ}$. El materialismo dialéctico como ontología. $2^{\underline{o}}$. El materialismo dialéctico como método. $3^{\text {oo }}$. El materialismo dialéctico como filosofía de la praxis. B) Materialismo dialéctico y concepción marxista del Derecho y del Estado. a) El Derecho y el Estado como productos de la estructura económico-social. b) La extinción del Derecho y del Estado. C) Teoría soviética del Derecho y del Estado: El aplazamiento de la extinción del Derecho y del Estado. a) La tesis de la "legalidad revolucionaria". b) La tesis de la "legalidad socialista". c)La tesis de "el Estado de todo el pueblo" y de "el Derecho de todo el pueblo". D) Consideraciones críticas. a) Plano científico. b) Plano ideológico: $1^{\circ}$. Paso del sociologismo al normativismo jurídico. $2^{\circ}$. Cambio en la valoración del Derecho como sistema normativo. $3^{\text {o. }}$. Viraje desde el "materialismo" al "idealismo". 4⿳‥ Del "humanismo marxista" al Estado totalitario. 2. Neomarxismo y uso alternativo del Derecho. A) Introducción. ¿Qué es el uso alternativo del Derecho?. La Doctrina. B) Los fines. C) El método. a) Momento intelectual: Conocimiento y crítica del Derecho burgués: $1^{\circ}$. Crítica del Estado liberal de Derecho. $2^{o}$. Crítica de la concepción burguesa del Derecho. $3^{\text {o. }}$. Crítica de la Ciencia jurídica dogmática. $4^{\circ}$. Crítica del método y de la praxis judicial tradicionales. b) Momento práctico: Legitimidad y posibilidad de una praxis jurídica alternativa: $1^{\circ}$. Justificación del "uso alternativo del Dere- 
cho". 2º . Posibilidad de una praxis jurídica alternativa. D) Hacia una nueva concepción del mundo jurídico. a) Una nueva concepción del Derecho. b) Una nueva concepción de la Ciencia jurídica. c) Una nueva concepción del método jurídico. E) Resultado. III. LA CONCEPCIÓN DEL DERECHO COMO INSTRUMENTO TÉCNICO EN LAS DOCTRINAS CIENTÍFICAS. 1. El utilitarismo jurídico de R. von Ihering. A) Hombre y sociedad. B) El Estado. C) El Derecho. a) El aseguramiento de la existencia y conservación de la sociedad. b) La promoción del desarrollo y la perfección de la sociedad. Notas del Derecho: $1^{\circ}$. La coercibilidad. $2^{\circ}$. La estatalidad. $3^{\circ}$. La generalidad y abstracción. D) Consideraciones críticas. 2. El formalismo normativista de $\mathrm{H}$. Kelsen. A) Meta y supuestos metodológicos del pensamiento de Kelsen. a) La concepción positivista de la Ciencia. b) La distinción entre "ser" (sein) y "deber ser" (sollen). c) La pureza metódica. B) Noción del Derecho. El Derecho como técnica de control social. a) La norma jurídica como mero "juicio hipotético". b) Distinción entre "norma jurídica" y "regla de Derecho". Carácter imperativo de la norma jurídica. c) Imperatividad y coactividad de la norma jurídica. C) Consideraciones críticas. 3. El realismo jurídico escandinavo. A) Noción y rasgos fundamentales. a) El positivismo lógico como supuesto epistemológico. b) La concepción del Derecho como hecho. c) La reducción de la Filosofía del Derecho a Teoría de la Ciencia jurídica. B) La concepción positivista de K. Olivecrona y la reducción tecnicista del Derecho a fuerza. a) Supuestos epistemológicos. b) La revisión de los conceptos jurídicos fundamentales como tarea primordial de la Ciencia jurídica. c) Significación técnica de las nociones de Derecho y de derecho subjetivo: $1^{\circ}$. El Derecho como sistema de reglas que regula el uso de la fuerza. $2^{\circ}$. Significación de la idea de derecho subjetivo.

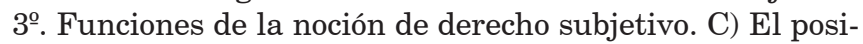
tivismo realista de A. Ross y la tecnificación de los conceptos centrales del pensamiento jurídico. a) Supuestos epistemológicos. b) Dimensión crítica y revisionista del pensamiento de A. Ross: $1^{\circ}$. La crítica como punto de partida. $2^{\text {o. }}$. Revisión de los conceptos jurídicos fundamentales. 4. El funcionalismo en el Derecho: Notas sobre N. Luhmann y G. Jakobs. A) Introducción. B) El pensamiento sistémico de N. Luhmann. a) El proyecto científico de Luhmann: $1^{\circ}$. La complejidad social. $2^{\circ}$. La limitación de la razón humana. $3^{\circ}$. El sistema como instrumento cognitivo. b) Teoría de la Sociedad: Autoreferencia y autopoiesis. c)Teoría del Derecho: $1^{\circ}$. El sistema jurídico. $2^{\circ}$. Los dere- 
chos fundamentales. $3^{\circ}$. La idea de Justicia. C) La concepción funcional del Derecho penal de G. Jakobs. a) La conservación de la sociedad como función primaria del Derecho. b) El Derecho como factor de identificación y garantía de la sociedad. c) Consecuencias. d) Consideraciones críticas. 5. El análisis económico del Derecho. A) Supuestos objetivos. B) Ámbitos de aplicación y tareas. C) Resultados. a) Reducción del Derecho a regla técnica. b) Funciones del Derecho. B) Consideraciones críticas. a) Aspectos positivos. b) Aspectos negativos. c) Primera aclaración: 1ํ․ Desplazamiento y sustitución de la idea de fin del Derecho por la idea de función. $2^{\text {o }}$. Desplazamiento y sustitución de la idea de validez jurídica por la de eficacia. $3^{\circ}$. Desplazamiento y sustitución del conocimiento filosófico del Derecho por el sociológico jurídico. d) Segunda aclaración. IV. CONSIDERACIONES CRÍTICAS. 1. Ámbito del conocimiento teórico del Derecho. A) Una concepción insuficiente del Derecho. B) Confusión y subversión en el plano y temática de la Filosofía del Derecho. 2. Ámbito de la praxis jurídica. A) Derecho y axiología. B) Derecho y fuerza. C) Derecho y formas políticas. 3. Necesidad y urgencia de reenquiciar las relaciones entre ética y técnica en el Derecho.

\section{LA PREOCUPACIÓN POR LA CIENTIFICIDAD DEL CONOCIMIENTO JURÍDICO}

Ha sido casi una constante de la historia del pensamiento jurídico la duda, cuando no la negación, de la "cientificidad" de la jurisprudencia (conocimiento jurídico), y el consiguiente complejo de inferioridad de los juristas frente a los cultivadores de las llamadas ciencias positivas (Matemáticas, Física, Química, Medicina, Ingeniería...).

De ahí que, a partir sobre todo de mediados del siglo XIX, se replantee de forma persistente la idea de aplicar al estudio del Derecho los métodos de las ciencias positivas con el fin de elevar dichos estudios a la condición de "verdadera ciencia". La realización de dicha tarea exigió, entre otras formalidades o requisitos:

1. La reducción del Derecho al Derecho positivo. No existe más Derecho que el Derecho positivo. 
2. La depuración del Derecho positivo de todo contenido o adherencia de carácter metafísico (teológico, ético, ideológico-político...) y su reducción a la condición de mero hecho o fenómeno empírico. Las ideas de Derecho natural, de Justicia, etc. fueron consideradas ilusiones, fantasías metafísicas que nada tenían que ver con las realidades que estudia la ciencia, siendo desterradas del ámbito del conocimiento científico.

3. La aplicación al estudio del Derecho de los métodos de las Ciencias positivas. Reducido el Derecho a un puro hecho o fenómeno empírico se entiende, coherentemente con ello, que la tarea de comprender y explicar el Derecho debe llevar a cabo en función de los principios y categorías conceptuales propios de las ciencias positivas (Lógica, Física, Sociología, Economía...), ya desde los supuestos de un determinado monismo metodológico y científico (caso de la Teoría pura del Derecho de Kelsen) o bien, en otros casos, desde la perspectiva más abierta y flexible de un pluralismo metodológico e interdisciplinar (historia, sociología, economía, psicología, etc.).

4. En virtud de este planteamiento epistemológico y metodológico el Derecho deja de ser entendido como norma ética - la cual, en cuanto implica una dimensión valorativa, no podría ser objeto de ciencia (la ciencia describe pero no valora)—, para configurarse como una mera regla técnica de organización y control social, caracterizada por la nota de "neutralidad axiológica". Esta neutralidad axiológica convierte al Derecho, entendido como regla técnica, en un objeto susceptible de ser tratado y estudiado con los métodos propios de las ciencias positivas, haciendo de su conocimiento una auténtica ciencia.

En virtud de este proceso el Derecho queda reducido a un mero instrumento técnico, en su significación prístina de medio necesario para alcanzar un fin.

La concepción del Derecho como instrumento técnico de ordenación y control social supone básicamente dos cosas: 
la vinculación del Derecho a la idea de fuerza y la configuración de la utilidad como fin último del Derecho.

Fuerza y utilidad aparecen aquí íntimamente vinculados. La utilidad hace referencia aquí a la adecuada relación entre medio y fin: útil es todo lo que permite alcanzar el fin perseguido. La fuerza, la coacción, en cuanto fuerza organizada, constituye el medio, el instrumento más adecuado y útil al Derecho para llevar a cabo su tarea de ordenación y control social.

La concepción del Derecho como regla técnica, como instrumento técnico de ordenación y control social, ha sido desarrollada por la doctrina desde diferentes supuestos epistemológicos e incluso ideológicos, apareciendo así una pluralidad de doctrinas que poseen en común las notas de ver en la utilidad o interés el fin del Derecho y en la fuerza (coacción) el medio o instrumento para la realización de dicho fin. Las relaciones entre Derecho y fuerza han sido entendidas de diferentes formas reductibles, desde un punto de vista lógico-sistemático, a tres planteamientos:

1. La fuerza como garantía de la eficacia del Derecho;

2. El Derecho como conjunto de reglas que tienen por objeto la regulación del ejercicio de la fuerza;

3. La fuerza como contenido del Derecho ${ }^{1}$.

Con todo, las doctrinas que han expuesto y desarrollado la tesis que concibe el Derecho como un instrumento técnico de ordenación y control social distan mucho de ser homogéneas. Unas descansan sobre supuestos de carácter estrictamente científicos; otras, como sucede con las corrientes de signo marxista, involucran supuestos que pueden tener carácter científico con otros de significación abiertamente ideológicos. Por ello, en nuestra exposición, vamos a ordenar — sin ánimo de exhaustividad- las doctrinas más significativas en dos grandes apartados:

1 Pérez Luño, A. E. Teoría del Derecho, (Una concepción de la experiencia jurídica), ed. Tecnos, Madrid, 1997, pp. 159 y 160. 
1. La concepción del Derecho como instrumento técnico en las teorías ideológico-políticas ${ }^{2}$.

2. La concepción del Derecho como instrumento técnico en las teorías jurídicas científicas.

\section{LA CONCEPCIÓN DE DERECHO COMO INSTRUMENTO TÉCNICO EN LAS TEORÍAS IDEOLÓGICO-POLÍTICAS}

\section{Marxismo y teoría soviética del derecho}

\section{A) Supuestos filosóficos}

\section{a) El materialismo histórico}

El materialismo histórico representa, en la interpretación marxista, el proceso histórico-natural del desarrollo de la sociedad, sobre la base de la utilización del método dialéctico. Formulado en sus rasgos fundamentales por Marx y Engels en La ideología alemana, constituye uno de los supuestos fundamentales de la filosofía marxista-leninista. Según el materialismo histórico las relaciones de producción constituyen los factores fundamentales y determinantes de todo el proceso de cambio y de transformación de las relaciones sociales ${ }^{3}$. Una formulación sintética de la significación del materialismo histórico en la interpretación de la historia, es la hecha por Marx en su Prólogo a la Crítica de la economía política. En él escribe Marx, a este respecto: "Mi primer trabajo emprendido para resolver las dudas que me asaltaban, fue una revisión crítica de la filosofía Hegeliana del Derecho...". "El resultado ge-

${ }^{2}$ En este apartado estudiaremos solamente el marxismo, la Teoría soviética del Derecho y la doctrina neomarxista del "uso alternativo del Derecho". No nos ocuparemos por razones de espacio y tiempo (se trata ya de doctrinas periclitadas) de las Teorías jurídico-políticas del Fascismo italiano y del Nacionalsocialismo alemán.

${ }^{3}$ Rosental, M. M. y Ludin, P. F. Materialismo histórico, en Diccionario de Filosofía, trad. esp. del ruso por Augusto Vidal Roget, Akal Ed, Madrid, 1975, pp. 302 a 303; Politzer, G. Principios elementales y fundamentales de la filosofía, Akal Ed. Madrid, 1975, pp. 171 y ss. 
neral a que llegué (tras proseguir estudios de Economía política) y que, una vez obtenido, sirvió de hilo conductor a mis estudios, puede resumirse así: En la producción social de su vida, los hombres contraen determinadas relaciones necesarias e independientes de su voluntad, relaciones de producción, que corresponden a una determinada fase de desarrollo de su fuerzas productivas materiales. El conjunto de estas relaciones de producción forma la estructura económica de la sociedad, la base real sobre la que se levanta la superestructura jurídica y política y a la que corresponden determinadas formas de conciencia social. El modo de producción de la vida material condiciona el proceso de la vida social, política y espiritual en general"4. Engels aclaró más tarde: "Según la concepción materialista de la historia, el factor que en última instancia determina la historia es la producción y la reproducción de la vida real (...). La situación económica es la base, pero los diversos factores de la superestructura que sobre ella se levantan... ejercen también su influencia sobre el curso de las luchas históricas y determinan, predominantemente en muchos casos, su forma"5.

${ }^{4}$ Prólogo a la Contribución a la crítica de la economía política, en MARX, C. y ENGELS, F. "Obras escogidas”, T. I. Ed. original: Ediciones en Lenguas Extranjeras, Moscú, Akal Ed. Madrid, 1975, pp. 372 y 373.

En análogo sentido Marx y Engels habían declarado: "Mas no discutáis con nosotros mientras apliquéis a la abolición de la propiedad burguesa el criterio de vuestras nociones burguesas de libertad, cultura, Derecho, etc. Vuestras ideas son en sí mismas producto de las relaciones de producción y de propiedad burguesa, como vuestro Derecho no es más que la voluntad de vuestra clase erigida en ley; voluntad cuyo contenido está determinado por las condiciones materiales de existencia de vuestra clase". Manifiesto del Partido Comunista, ibíd. p. 38. Cfr. Engels, F. Contribución al problema de la vivienda, ibíd. pp. 654 y 655; Ludwig Feuerbach y el fin de la filosofía clásica alemana, ibíd. T. II, Ed. original: Ediciones en Lenguas Extranjeras, Moscú, Akal Ed, Madrid, 1975, pp. 418 y 419; Carta a J. Bloch (21-22 de septiembre de 1890), ibíd. pp. 520 y ss.; Carta a K. Schmidt, (27 de octubre de 1890), ibíd. pp. 526 y ss.

${ }_{5}$ Carta a J. Bloch, cit., p. 520.

Desde estos supuestos Elías Díaz ha criticado la concepción mecanicista del marxismo que tiende a considerar al Derecho y al Estado "como meros productos reflejos, inertes, pasivos (...), simples epifenómenos de la estructura económicosocial, sin incidencia alguna sobre ella". Marx y la teoría marxista del Derecho y del Estado, en "Sistema" (Revista de Ciencias Sociales), Núms. 38-39, Octubre, 
Desde los supuestos de la concepción materialista de la historia, la lucha de clases constituye para Marx y para Engels el motor y la forma del desarrollo histórico de la humanidad: "La historia de todas las sociedades que han existido hasta nuestros días — declaran Marx y Engelses la historia de las luchas de clases. Hombres libres y esclavos, patricios y plebeyos, señores y siervos, maestros y oficiales, en una palabra: opresores y oprimidos, se enfrentaron siempre, mantuvieron una lucha constante, velada unas veces y otras franca y abierta; lucha que terminó siempre con la transformación revolucionaria de toda la sociedad o el hundimiento de las clases beligerantes" 6 .

\section{b) El materialismo dialéctico}

El materialismo dialéctico es la base filosófica del marxismo $^{7}$, y constituye el resultado de un proceso de generalización desenvuelto fundamentalmente por Engels ${ }^{8}$, a partir de los datos suministrados por el "materialismo histórico", con el fin de justificar teoréticamente la concepción materialista de la historia (materialismo histórico) y elevarse a una interpretación global de la realidad toda.

1980, p. 30, véase 30 y ss. Sobre el materialismo histórico LefEVRE, H. El materialismo dialéctico, trad. esp. de Rubén A.N. Laporte, Ed. La Pleyade, Buenos Aires, 1974, pp. 77 y ss.; HARNECKER, M. Los conceptos elementales del materialismo histórico, Presentación por Louis Althusser, 4ํ․ Ed. Siglo Veintiuno Ed, Madrid, 1975, pp. 227 y ss., 229 y ss.; Stoyanovitch, K. Marxisme et Droit, Librairie Generale de Droit e de Jurisprudence, Paris, 1964, pp. 45 y ss.; BreIHER, E. Los temas actuales de la filosofía, trad. esp. de Florentino Pérez, Cuadernos Taurus, Taurus Ed. Madrid, 1966, pp. 58 y 59; ACÁRIZ BRAÑA, F. Introducción al marxismo, Ed. Prensa Española -Magisterio Español- Ed. Nacional, Barcelona, 1976, pp. 68 y ss.

${ }^{6}$ Manifiesto del Partido Comunista, cit., pp. 21 y 22.

7 Rosental, M. M. y Ludin, P. F. Materialismo dialéctico, en op. cit., p. 300; Weigt, P. Materialismo dialéctico, en "Diccionario de Ciencia Política" (Dirigido por Axel Görlitz), trad. esp. de Jaime Nicolás Muñiz y Germán López Orfanel, Alianza Ed. Madrid, 1980, p. 392; SтоYANovitch, K. Marxisme et Droit, cit., pp. 51 y ss.

8 Mathieu, V. Temas y problemas de la Filosofía actual, trad. esp. de Joaquín Campillo, Ed. Rialp, Madrid, 1980, pp. 182, 183, 186 y 187; OCÁRIZ BraÑA, F. Op. cit., pp. 71, 83, 91 y 92 . 
El materialismo histórico quedó así reducido a una parte o capítulo del materialismo dialéctico.

El materialismo dialéctico se configura así como una ontología, como un método y como una filosofía de la praxis.

\section{1ํ) El materialismo dialéctico como ontología}

El materialismo dialéctico se configura como una visión unitaria del mundo que pretende "abarcar tanto al mundo inorgánico como al material orgánico — con inclusión de la sociedad humana-, la conciencia y la totalidad de las actividades humanas. Apunta a una interpretación filosófica de la esencia del mundo, investigando a estos efectos la relación de la conciencia con la realidad, que es considerada como objetiva, existente fuera e independientemente de la conciencia (Lenin), decidiéndose Engels (Grundfragen der Philosophie) por el primado de la materia y de lo material frente al mundo de la conciencia, que viene entendido como producto, propiedad y función de la materia organizada en su grado sumo, y tratando las legalidades generales en la naturaleza, la sociedad y el pensamiento humano"9.

Los principios o leyes generales gracias a las cuales acontecen los procesos de movimiento y cambio de la materia, el paso de sus formas inferiores a las superiores, fueron formuladas por Engels quien - extendiendo a la naturaleza, a la realidad toda, las leyes dialécticas que Marx había aplicado a la historia- estableció las siguientes leyes: Primera: la del "paso de la cantidad a la cualidad"; Segunda: la de la "mutua compenetración de los opuestos", y tercera, la ley de la "negación de la negación" 10 .

\section{$2^{\circ}$ ) El materialismo dialéctico como método}

La dialéctica es el método que permite conocer con certeza no sólo el proceso histórico de transformación de la

9 Weigt, P. Op. cit., p. 392.

10 Rosental, M. M. y Ludin, P. F., cit., p. 301; Weigt, P. Op.cit., p. 393; PolitZeR, G. Op.cit., pp. 117 y ss.; 207 y ss.; Mathieu, V. Op. cit., p. 183. 
sociedad, sino también el proceso de transformación y cambio de la realidad toda, posibilitando con ello, mediante la eliminación de las contradicciones de la sociedad, su transformación revolucionaria en una sociedad sin clases, sin contradicciones, en una sociedad comunista. El materialismo dialéctico se configurará así, pues, como el método que permite alcanzar el nivel más elevado y riguroso del conocimiento, que es el propio de la filosofía y de la ciencia marxistas ${ }^{11}$.

Con todo, la dialéctica, más que un método científico, constituye un arma ideológica para la lucha política, en la cual desemboca el materialismo dialéctico al configurarse como "filosofía de la praxis".

$3^{\text {o) }}$ El materialismo dialéctico como filosofía de la praxis

Marx había escrito: "Los filósofos no han hecho más que interpretar de diversos modos el mundo, pero de lo que se trata es de transformarlo"12. Desde estos supuestos, el materialismo dialéctico se configura no, como otros sistemas, como una contemplativa ciencia de ciencias, sino sobre todo como una guía para la transformación del mun$\mathrm{do}^{13}$. Lo que pretende el materialismo dialéctico es comprender el mundo tal como es, con ayuda del método dialéctico, para transformarlo ${ }^{14}$, con lo cual la ontología y la metodología se prolongan y desembocan en "una guía para la acción".

\section{B) Materialismo dialéctico y concepción marxista del Derecho y del Estado}

El primer resultado del método dialéctico es el materialismo el cual, por lo que aquí nos interesa - la investiga-

11 GaRAudy, R. Introducción a la metodología marxista, Ed. Meridiano, Buenos Aires, 1964, p. 57.

${ }_{12}$ Tesis sobre Feuerbach, (Tesis XI), en Op. cit., T. II, p. 428.

13 Weigt, P. OP. cit., p. 394.

14 Rosental, M. M. y Ludin, P. F. Materialismo dialéctico, cit., pp. 300 y 301. 
ción del Derecho y el Estado- va a configurar toda la realidad jurídico-política y el conocimiento de la misma. Marx sostenía que después de una época de madurez filosófica como había sido la de Hegel, era necesario — por la lógica misma de la dialéctica - una ruptura con las doctrinas aceptadas, que ya no podían seguir progresando, constituyendo el único medio de avanzar la sustitución del idealismo de Hegel por un nuevo principio: el materialismo. Para Marx la única salida que se ofrecía a la superación de las contradicciones internas de la filosofía hegeliana era el materialismo dialéctico, plenamente consciente de que la historia era "el proceso de evolución de la humanidad" y cuya tarea consistía en descubrir las leyes que mueven este proceso.

\section{a) El Derecho y el Estado como productos de la estructura económico-social}

La teoría jurídica marxista, emanada directamente de Marx y Engels como consecuencia de la aplicación del materialismo dialéctico, es de signo eminentemente histórico y sociológico en tanto que coloca al Derecho y al Estado en estricta dependencia de una concreta organización social y económica. El marxismo pretende eliminar así todos los residuos idealistas y metafísicos de una manera radical. "En el Derecho no hay nada autónomo, intrínseco, racionalmente emanado de la mente como norma conformadora de la conducta. Los apotegmas del Derecho natural son precipitados históricos del sujeto histórico, que es el hombre condicionado por la materia"15. El Derecho y el Estado son para Marx solamente un epifenómeno de las relaciones de producción y cambio sin perjuicio de que las instituciones jurídico-políticas condicionen, a su vez, la realidad socio-económica ${ }^{16}$.

15 Hernández Gil, A. Metodología de la Ciencia del Derecho, Vol. II, Madrid, 1971, p. 93. Véase las pp. 92 y 96.

16 Stoyanovitch, K. Marxisme et Droit, cit., pp. 74 y ss.; LefEvre, H. De l'Etat, T. II, (De Hegel a Mao por Stalin), Union Générale d'Editions, París, 1976, pp. 212 y ss. Miliband, R. Marx y el Estado, en el vol. "Marx, el Derecho y el Es- 
Según esta concepción, el Derecho carece así de toda autonomía. No puede ser entendido más que como un simple reflejo o producto de una fase del proceso económico, cuya significación última es la de constituir un instrumento técnico de dominación de los explotadores que lo emplean en interés de su clase. El Derecho carece en absoluto de dignidad y de sentido ético, constituyendo un simple instrumento técnico de opresión de las clases dominantes.

\section{b) La extinción del Derecho y del Estado}

Para Marx el socialismo sería un sistema superior al capitalista que lo precedía en el cual, desaparecidas las clases, se podría prescindir de los instrumentos de dominación constituidos por el Derecho y el Estado. En la sociedad comunista el Derecho y el Estado se desvanecerían y serían reemplazados por una mera "administración de las cosas". "Una vez que en el curso del desarrollo — dicen Marx y Engels - hayan desaparecido las diferencias de clase y se haya concentrado toda la producción en manos de los individuos asociados (...), en sustitución de la antigua sociedad burguesa, con sus clases y sus antagonismos de clase, surgirá una asociación en que el libre desenvolvimiento de cada uno será la condición del libre desenvolvimiento de todos"17.

Más explícito resulta al respecto Engels: "Las clases desaparecerán de un modo tan inevitable como surgieron en su día. Con la desaparición de las clases desaparecerá inevitablemente el Estado. La sociedad, reorganizando de un modo nuevo la producción sobre la base de una asocia-

tado", trad. esp. de Juan Ramón Capella, Oikos-Tau Ed. Barcelona, 1969, pp. 49 y ss. El profesor Elías Díaz ha advertido sobre el falseamiento del pensamiento de Marx que implicaría una interpretación mecanicista, rígida, de la influencia de la infraestructura económica en la superestructura jurídico-política. Véase DíAZ, E. Marx y la teoría marxista del Derecho y del Estado, cit., pp. 30 y ss. Sobre esta cuestión véanse las citas a las obras de Marx y Engels que aparecen recogidas en las notas 4 y 5 de este texto.

${ }_{17}$ Manifiesto..., cit., p. 43. Véase MARX, C. Críticas del programa de Gotha, en op. cit., T. II, p. 36. 
ción libre de productores iguales, enviará toda la máquina del Estado al lugar que entonces le ha de corresponder: al museo de antigüedades, junto a la rueca y al hacha de bronce" 18 .

\section{C) Teoría soviética del Derecho y del Estado: El} aplazamiento de la extinción del Derecho y del Estado

El triunfo de la revolución comunista y los nuevos problemas políticos planteados a la Unión de Repúblicas Socialistas Soviéticas obligaron a una revisión de la teoría jurídica marxista - que constituye una corrección sustancial de la misma - en el sentido de ver en el Derecho no una mera superestructura que había de ir desapareciendo gradualmente a medida que la Revolución Socialista se fuese consolidando, sino un sistema o instrumento técnico de normas establecido por el Estado como expresión de la voluntad popular - la nueva posición implica un radical voluntarismo- y ordenado, de un lado, a eliminar todos los residuos del capitalismo y a edificar la sociedad comunista, en el orden interno, y, de otro lado, a consolidar, proteger y defender al Estado soviético, frente a la amenaza y a los ataques externos de las fuerzas capitalistas.

Esta posición implica un replanteamiento de la tesis marxista de la extinción del Derecho y del Estado. La tesis de la desaparición del Derecho y del Estado, no es negada, pero su realización resulta aplazada hasta un lejano en incierto día.

Ese replanteamiento de la tesis de la extinción del Derecho y el Estado, y su consiguiente aplazamiento, ha

${ }^{18}$ El origen de la familia, de la sociedad y el Estado, ibíd. p. 340. Véase De la autoridad, ibíd. T. I, p. 671; Del socialismo utópico al socialismo científico, ibíd. T. II, pp. 155 y 156.

Véanse Stoyanovitch, K. Marxisme et Droit, cit., pp. 98 y ss.; Sobre la problemática de una reinterpretación del Dogma de la extinción del Derecho y el Estado en Marx, véase DíAz, E. Marx y la teoría marxista..., cit., pp. 37, 39 a 42, $60 \mathrm{y} \mathrm{ss.}$ 
encontrado tres formulaciones fundamentales: la tesis de la "legalidad revolucionaria", la tesis de la "legalidad socialista" y la tesis de "el Estado y el Derecho de todo el pueblo".

\section{a) La tesis de la "legalidad revolucionaria"}

Dicha tesis auspiciada por Lenin ${ }^{19}$ y desenvuelta con ligeras variantes, por Rejsner ${ }^{20}$, Stucka ${ }^{21}$ y Pasukanis $^{22}$, fundamentalmente, sostiene que el Derecho y el Estado deberán subsistir — como instrumentos revolucionariosmientras dure la "dictadura del proletariado". El Estado burgués no se extinguirá de modo espontáneo en el curso de la historia, sino que deberá ser destruido mediante la "dictadura del proletariado". Sólo se extinguirán espontáneamente el Derecho y el Estado proletarios, con el paso de la sociedad socialista a la sociedad comunista ${ }^{23}$.

19 Decía Lenín: "Ciertamente el Derecho burgués, por lo que se refiere a la repartición de los objetos de consumo, supone necesariamente un Estado burgués, puesto que el Derecho no es nada sin aparato capaz de obligar a la observancia de las reglas jurídicas. De ahí se deriva que en el régimen comunista subsisten, durante cierto tiempo, no sólo el Derecho burgués sino también el Estado burgués sin burguesía”. Estado y revolución, Ed. Ayuso, Madrid, 1975, p. 121 .

${ }^{20}$ La teoría de Petrazyki, el marxismo y la ideología social, 1908; El Derecho: nuestro Derecho, el Derecho extranjero, el Derecho en general, 1925. Sobre la teoría jurídica de Rejsner, véase KELSEN, H. Teoría comunista del Derecho y del Estado, trad. esp. de Alfredo J. Weiss, Emecé Ed. Buenos Aires, 1957, pp. 115 y ss.

${ }_{21}$ La función revolucionaria del Derecho y del Estado. Hay trad. esp. de Juan Ramón Capella, 2 $2^{\text {a }}$ ed. Ed. Península, Barcelona, 1974. Sobre esta teoría jurídica de Stucka véase KELSEN, H. Teoría comunista..., cit., pp. 95 y ss.

22 Teoría general del Derecho y Marxismo, trad. esp. de Virgilio Zapatero, Ed. Labor, Barcelona, 1976.

23 Kelsen, H. Teoría comunista..., cit., pp. 131 y ss.; STOYAnOvitCH, K. La Philosophie du Droit en U.R.S.S., (1977-1953), Librairie Générale de Droit y Jurisprudence, París, 1965, pp. 21 y ss., 43 y ss., 69 y ss., 96 y ss., 135 y ss.; CoNDE, R. Sociedad, Estado y Derecho en la filosofía marxista, Ed. Cuadernos para el Diálogo, Madrid, 1968, pp. 149 y ss., 153 y ss.; JoHnson, E. L. El sistema jurídico soviético, trad. esp. de J. R. Capella y J. Cano Tembleque, Ed. Península, Barcelona, 1974, pp. 97 y ss.; CERRONI, U. El pensamiento Jurídico soviético, trad. esp. de Virgilio Zapatero y Manuel de la Rocha, Ed. Cuadernos para el Diálogo, Madrid, 1977, pp. 58 y ss., 65 y ss., 75 y ss., 122 y ss., 136 y ss. 
b) La tesis de la "legalidad socialista"

Surge para tratar de armonizar con los supuestos ideológicos marxistas el fenómeno de fortalecimiento que experimenta el Derecho a raíz del acceso de Stalin al poder, y el nuevo estado de cosas consagrado por la Constitución de 1936. Se trata en definitiva de una construcción ideológica para legitimar la dictadura personal de Stalin, que implicaba un replanteamiento y un aplazamiento "sine die" del tema de la extinción del Derecho y del Estado. A este respecto las tesis de Stalin eran:

- Primera: Necesidad de fortalecer al máximo el Derecho y el Estado soviéticos en orden a la edificación de la sociedad comunista (el Derecho y el Estado constituyen instrumentos imprescindibles del desarrollo de la economía socialista y de la revolución cultural) y a la defensa de la sociedad soviética frente a la amenaza del "cerco capitalista" (el Derecho y el Estado se configuran como instrumentos de lucha frente a los enemigos interiores y al cerco exterior del capitalismo internacional).

- Segunda: El Derecho y el Estado soviético permanecerán hasta la desaparición del cerco capitalista y el triunfo del comunismo en todo el mundo ${ }^{24}$.

Desde estos supuestos se opera una revisión de la teoría jurídico-política soviética. "El marxismo enseña - dice Vyshinsky, principal artífice junto con Yundi de la revisión del pensamiento jurídico en esta nueva dirección- que es necesario utilizar el Derecho como uno de los medios de lucha por el Socialismo, como uno de los medios técnicos para transformar la sociedad humana sobre bases socialistas. El Derecho soviético está enteramente dirigido contra la explotación y los explotadores. El Derecho soviético es el Derecho de un Estado Socialista llamado a servir a la lucha contra los enemigos del so-

${ }^{24}$ Stoyanovitch, K. La Philosophie du Droit, cit., pp. 236 y ss.; Conde, R. Op. cit., pp. 39, 40 46, 75, 76 y 157 a 160. 
cialismo y a la causa de la construcción de la sociedad socialista" 25 .

El Derecho cobra en esta nueva versión una radical significación instrumental y voluntarista: "Nuestro Derecho - dice Vishinsky - es la voluntad de nuestro pueblo elevada al rango de ley". La norma jurídica socialista, explica Jamposkaja, es "una regla de conducta que expresa la voluntad del pueblo, establecida por el estado soviético y formulada por órganos estatales" ${ }^{26}$. Esta posición supone una recaída en el voluntarismo, en el decisionismo político.

Desde estos supuestos el pensamiento jurídico soviético, por razones puramente pragmáticas, de oportunidad política, parece separarse de la doctrina marxista ortodoxa y aproximarse a una posición de cuño estrictamente jurídico-positivista al afirmar la necesidad del Derecho y de su estabilidad así como una estricta aplicación de las leyes.

c) La tesis de "el Estado de todo el pueblo" y de "el Derecho de todo el pueblo"

Tras la muerte de Stalin y, de modo oficial, a partir del XX Congreso del P.C.U.S. (febrero de 1956) se inicia un proceso de revisión del pensamiento político soviético ("desestalinización"), que se va a ir perfilando en posteriores congresos, y cuyos frutos más significativos serán la elaboración del nuevo Estatuto y del nuevo programa del P.C.U.S. (XXII Congreso, octubre de 1961) y que culminará con la promulgación de la nueva Constitución de la U.R.S.S. (7 de octubre de 1977).

Dicho proceso de revisión implica una denuncia y condena de las tesis stalinistas y, por lo que más interesa al pensamiento político-jurídico, un nuevo replanteamiento

${ }^{25}$ Fragen des Rechts und des Staats bei Marx, en "Sowjetiche Beiträgue zur Staat-und Rechtstheorie". 36 Beiheft zur "Sowjetwissenschaft", Verlag Kultur und Fortschritt G.m.b.H., Berlín, 1953, pp. 7 y ss.; Die Hauptaufgaben der Wissenschaft von sozialistischen Sowjetrecht, en Ibíd. pp. 50 y ss.

${ }^{26}$ Rechsnorm und Rechtsverhältnis, ibíd. pp. 362 y 363. 
del problema de la extinción del Derecho y del Estado y, en el fondo, un movimiento de renovación de la Ciencia jurídica soviética ${ }^{27}$.

En relación con el Estado se afirma que la "dictadura del proletariado" ha concluido y que el Estado soviético ha entrado en una nueva etapa: la de "el Estado de todo el pueblo". Dicha tesis sostiene que el Estado perdurará hasta la victoria total del comunismo, si bien —en virtud de la democracia socialista- sometido a un constante proceso de transformación de los órganos del poder estatal en órganos de administración social. Se señalan fechas, dentro del proceso gradual de extinción del Estado, afirmándose que el Partido Comunista no se extinguirá en el curso del mismo, puesto que se fundamenta y encarna valores morales necesarios siempre al hombre.

En esta tercera etapa de "el Estado de todo el pueblo", el Derecho soviético se transforma en "el Derecho de todo el pueblo". El "Derecho de todo el pueblo" es concebido como un conjunto de normas -expresión de la voluntad del pueblo soviético-, instrumento técnico y necesario para la construcción del comunismo, y sancionado por el poder del Estado. Dicho sistema normativo aparece caracterizado, fundamentalmente, por su función educadora de la comunidad en los valores de la convivencia socialista, y, de modo subsidiario, por su coercibilidad, en el sentido de que a medida de que se vaya incrementando su eficacia educadora irá cediendo su significación coactiva. La doctrina de "el Derecho de todo el pueblo" entiende que, en un proceso simultáneo al de la extinción del Estado, dicho Derecho será sustituido progresivamente por normas de moral y de convivencia social $^{28}$.

27 LAVIQUE, P. Les nouvelles tendences méthodologiques de la science juridique sovietique, en "Annuaire de l'U.R.S.S. et des Pays socialistes Européens", 1965, pp. 123 y ss.

28 CONDE, R. Op. cit., pp. 49 y ss., 120 y ss., 127 y ss., 189 y ss., 193 y ss. Johnson, E. L. Op. cit., pp. 103 y ss, CERRONI, U. El pensamiento..., cit., pp. 104 y ss. 
D) Consideraciones críticas

Un balance sucinto de la significación del marxismo en relación con el Derecho - y ajustado a la perspectiva de nuestro estudio - aconseja distinguir dos planos: el científico, considerado en sentido amplio, y el puramente ideológico.

\section{a) Plano científico}

Desde el punto de vista científico el marxismo ha tenido el mérito de llamar la atención sobre la importancia del factor económico en la vida del Derecho, si bien esa importancia no ha sido absoluta ni unilateral y ha variado históricamente en el espacio y en el tiempo.

En otro orden de cosas hay que decir que la característica más significativa del pensamiento jurídico marxista es la escasez y mediocridad de sus aportaciones.

La escasez de sus contribuciones tiene una fácil explicación: En un principio, los líderes soviéticos, fieles a la tesis marxista de la desaparición del Derecho y del Estado tras el periodo transitorio de la "dictadura del proletariado", siguieron pensando que el Derecho era un residuo de la sociedad burguesa que iría desapareciendo con la progresiva socialización de la sociedad, en vista de lo cual el Derecho llamó poco la atención del pensamiento marxista. La escasa producción científica de este periodo sobre el Derecho (Bujarin, Stucka, Rejsner, Goichbarg, Pasukanis) no hace más que subrayar esta vieja tesis del dogma marxista, según la cual el Derecho, en cuanto objeto de estudio, tenía una importancia transitoria.

Respecto de la mediocridad del pensamiento jurídico marxista cuando no de su condición espuria, al revestir de apariencia científica tesis puramente ideológicas, cabe decir que ello es la consecuencia lógica de la falta de libertad y del dogmatismo que ha limitado y constreñido el pensamiento de los juristas en la Unión Soviética y, en general. en el seno del Partido Comunista. La constante presión y condicionamiento de la teoría y de la práctica 
política sobre el pensamiento jurídico ha convertido a éste en un apéndice de la política que trata de explicar y justificar, desde el ámbito jurídico y con razonamientos frecuentemente sofísticos, tesis y planteamientos de carácter político, apareciendo toda su teoría jurídica lastrada por el más burdo utilitarismo político: para Lenin era "honrado y moral lo que contribuye a la destrucción del viejo mundo" 29 .

\section{b) Plano ideológico}

Desde una perspectiva ideológica la teoría jurídica marxista se ha caracterizado por sus constantes oscilaciones en función del interés y la utilidad políticos del momento. Ello ha generado en la misma numerosas tensiones y contradicciones.

Las tensiones y contradicciones a las que ha estado sometido el pensamiento jurídico marxista, reducido a un apéndice instrumental de la teoría y de la praxis políticas, podrían resumirse, sin ánimo de exhaustividad, en las siguientes inflexiones y virajes.

\section{$1^{\circ}$. Paso del socialismo al normativismo jurídicos}

En un principio el Derecho fue entendido por el marxismo como un epifenómeno de la infraestructura económica de la sociedad burguesa y capitalista. En cuanto tal el marxismo tuvo una concepción del Derecho eminentemente histórica y sociológica. Esta fue la tesis, por ejemplo, de Stucka y Pasukanis, enraizada directamente en las doctrinas de Marx y Engels.

Posteriormente, con el aplazamiento y la revisión del dogma de la extinción del Derecho y del Estado y por razones de mera estrategia y utilidad políticas, se produjo el viraje hacia una concepción normativista del Derecho (reforzamiento de la legalidad socialista por Stalin y Vyshinsky), más apta para hacer del mismo un instrumento

${ }^{29}$ Bochenski, I. M. El materialismo dialéctico, cit., pp. 124, 125 y 126. 
técnico al servicio de la "revolución"; como medio más eficaz para la erradicación y destrucción de la sociedad burguesa y la construcción del socialismo.

\section{$2^{\text {o. }}$ Cambio en la valoración del Derecho como sistema normativo}

Vinculada a la congelación del dogma de la extinción del Derecho y del Estado en la sociedad socialista se produce un cambio en la estimación del Derecho. Si en la sociedad burguesa el Derecho aparece desprovisto de toda dignidad y sentido ético en cuanto constituye un instrumento técnico de dominación y opresión al servicio de la clase burguesa, en la sociedad socialista esta valoración cambia radicalmente. En la sociedad socialista el Derecho, en cuanto normatividad emanada del Estado socialista, posee el mayor valor y significación puesto que es reflejo y expresión de "la voluntad del pueblo trabajador". El Derecho es ahora, con el orden interno, un instrumento, un medio técnico imprescindible, para la defensa y protección del socialismo y la erección final de una sociedad comunista; $y$, en el orden exterior, un eficaz instrumento de lucha para resistir y destruir el "cerco capitalista".

\section{$3^{\circ}$. Viraje desde el "materialismo" al "idealismo"}

Inicialmente el marxismo, desde los supuestos del materialismo histórico y del materialismo dialéctico, vio en el Derecho un simple epifenómeno de la estructura y dinámica de los medios económicos de producción de la sociedad capitalista (infraestructura económica). El Derecho (el Derecho burgués) fue considerado como un producto sociológico de significación puramente económica, material (materialismo). Pero esa significación cambiaría en el curso del devenir histórico cuyo final inexorable - según la Filosofía de la historia marxista - supondría el desplazamiento y supresión de la sociedad burguesa (sociedad de explotación del hombre por el hombre) y su 
sustitución por la "sociedad socialista", primero, "comunista" después. Pero en este tránsito, que debería haber supuesto la emancipación, la "liberación del hombre", la "desaparición de la propiedad privada", y la "conquista de la igualdad" en una única "sociedad sin clases", el Derecho, la "legalidad socialista" y "comunista", se transmuta en cuanto instrumento de ese cambio revolucionario y se carga de dignidad y eticidad, por el "humanismo" de los valores a los que sirve. Según las teorías marxistas dicho Derecho, en cuanto "Derecho de todo el pueblo", entraña una función paidética, educadora de los hombres en los "valores de la convivencia socialista" (lo cual no está nada claro en qué consiste).

Para el pensamiento marxista esa "sociedad sin clases" es valiosa, es "una sociedad justa" — diríamos nosotros-, y como observa Fassón ${ }^{30}$, aunque ese resultado, según la Filosofía de la Historia marxista, no se presenta como "un ideal con el que la realidad deba conformarse" sino como un "movimiento real (necesario) que suprime el estado de cosas presentes" (Marx-Engels, La ideología alemana), de hecho ha funcionado como una ideología (utopía) que ha sido sentida y vivida como un ideal (idealismo) por el que merece la pena y constituye un deber luchar e incluso morir. Así ha sido históricamente.

\section{4º . Del humanismo marxista al Estado totalitario}

Posiblemente el pensamiento marxista en lo que acabamos de llamar su idealismo (liberación del hombre, desaparición de las clases sociales, igualdad, acceso a todos los bienes, etc.) fuese y siga siendo sincero en muchas de las mentes que lo han formulado y que, aún hoy, de buena fe, continúan haciéndolo. Sin embargo estas ideas no se compadecen con la realidad histórica. Desde el primer momento del triunfo de la Revolución comunista en Rusia

30 Fassó, G. La Filosofia del Diritto dell'Ottocento e del Novecento, (Nueva edizione aggiornata a cura di C. Faralli e G. Zanetti, Ed. il Mulino, Bologna, 1994, pp. 118 y 119. 
(1917) hasta el comienzo del hundimiento del Régimen soviético en 1989 —y lo que decimos de la Unión Soviética es extensible a los otros regímenes del mismo signo que aún subsisten- la experiencia histórica del marxismo constituye, desde el punto de vista histórico, la más alta, duradera y cruel expresión del Estado Totalitario. Del humanismo idealista del periodo prerrevolucionario se ha caído, a raíz del triunfo de la Revolución comunista, tanto en $\mathrm{Ru}-$ sia como en otros países donde aún domina la Revolución, en el más radical y cruel de los totalitarismos, bajo la inhumana y férrea dictadura de los partidos comunistas. Esta cruel dictadura de partido que ha contado siempre en Occidente, sobre todo en Francia y en Italia, con la complicidad y cobertura de la izquierda - en especial de una "dilettante intelectualidad de salón, progresista y de izquierdas" ("divine gauche") — empeñada siempre, sin haber sufrido sus rigores, en ocultar la realidad de la experiencia del marxismo y en hacerla presentable. Dicha dictadura marxista se ha plegado siempre a las exigencias de la $R e$ alpolitik del ejercicio efectivo y utilitario del poder en beneficio, no del pueblo sino de unas nuevas élites, de una nueva "clase dominante": la marxista-comunista.

\section{Neomarxismo y uso alternativo del derecho}

\section{A) Introducción. ¿Qué es el uso alternativo del Derecho? La Doctrina}

La actitud crítica y militante del pensamiento marxista, bajo la apariencia de una renovación doctrinal y metodológica, se ha plasmado en el último tercio del siglo XX en su preocupación e interés por la reforma y nueva orientación de la teoría y la praxis jurídicas. Este neomarxismo ha cristalizado en las llamadas teorías críticas del Derecho, empeñadas en depurar la teoría y la práctica del Derecho de sus raíces y adherencias burguesas, y en hacer del Derecho un instrumento de lucha orientado a la construcción —desde una perspectiva siempre socialista, neo- 
marxista- de una sociedad más libre, igualitaria y progresista $^{31}$. Uno de los ejemplos más característicos de esta corriente de pensamiento quizá sea el conocido bajo la denominación de "uso alternativo del Derecho".

Bajo la bandera del "uso alternativo del Derecho" se aglutinan un grupo de personas definido por dos claros rasgos: el ideológico y el profesional.

Desde el punto de vista ideológico se trata de personas con un claro compromiso con el socialismo y el marxismo más o menos renovado que, en cualquier caso, se trasluce de inmediato en su lenguaje.

Desde la perspectiva profesional destaca la condición de juristas de los miembros de dicho movimiento. Se trata de un nuevo tipo de revolucionario, dedicado profesionalmente al Derecho, y que ha encontrado su campo de actuación en las facultades de Derecho, en los Tribunales de Justicia, en la Administración Pública y determinados bufetes de abogados. El aura con que se envuelve y nimba su actuación social como profesor, juez o abogado, es la del "progresismo". Dicho "progresismo", consciente de la importancia del Derecho en la vida social y política, pretende, para sus fines, modificar la vida jurídica cambiando la enseñanza del Derecho y la práctica ordinaria de los profesionales del mismo (jueces, abogados, etc.), haciendo del Derecho un arma para la lucha al servicio de su ideología revolucionaria.

El movimiento de "uso alternativo del Derecho" ha de entenderse lógicamente en función del contexto histórico, político y social en que aparece. Dicho movimiento nace en Italia, en los años setenta del siglo XX, en una situación política de crisis, con un mundo escindido en dos bloques por la "guerra fría". De un lado, el bloque occidental, integrado básicamente por países dotados de un régimen liberal y democrático o en vías de alcanzarlo. De otro lado, el bloque oriental o soviético integrado por los países donde regía el denominado "socialismo real", dotados de regíme-

31 PÉRez Luño, A. E. Trayectorias contemporáneas de la Filosofía y la Teoría del Derecho, Innovación Editorial Lagares, Sevilla, 2003, pp. 73 y 74. 
nes políticos totalitarios vertebrados e impulsados por la dictadura del Partido Comunista.

En esta situación, fresco aún el recuerdo de la guerra mundial y vivas las tensiones políticas entre bloques, los partidos comunistas de la Europa occidental moderaron su lenguaje y sus tácticas (las palabras guerra, revolución, etc. no sonaban bien en aquel contexto) y se presentaron como luchadores por la democracia, si bien hicieron ojos ciegos y oídos sordos a la situación dramática de los países del este de Europa, situación que, lejos de condenar, se esforzaron en ocultar y, en cualquier caso, en justificar. Para el "progresismo" el "socialismo real" constituía un momento cualitativo superior al representado por la sociedad burguesa, capitalista, liberal y democrática.

Ese es el momento en que en la vida política aparece el Eurocomunismo (Francia, Italia, España) y en el ámbito del pensamiento jurídico surge, en Italia, como ya se ha indicado, la doctrina del uso alternativo del Derecho. Dicha doctrina pretende impulsar, desde el mundo jurídico, una praxis revolucionaria, pero silenciosa y poco comprometida $^{32}$, que sin embargo no renuncia a la consecución de los objetivos del marxismo pero que, por el momento, se ve obligada a continuar la "lucha de clases" por otros medios; esto es, mediante el "uso alternativo del Derecho" 33 .

La doctrina del "uso alternativo del Derecho", surgida en Italia, experimentó una entusiasta acogida en España, por parte de los sectores autodenominados "progresistas", pertenecientes al mundo universitario y a la carrera judicial y fiscal. Entre las principales figuras de dicho movimiento debe destacarse a los italianos P. Barcellona, G. Cotturi, L. Ferrajoli, S. Senese, V. Accattasis, G. Tarello, L. de Marco y F. Mesiani, entre otros.

La obra más significativa de esta corriente doctrinal son los libros colectivos L'uso alternativo del Diritto, (2

${ }^{32}$ ANDRÉs IBÁÑEz, P. Uso alternativo del Derecho y práctica judicial, en el vol. "Sobre el uso alternativo del Derecho", Fernando Torres-Editor, Valencia, 1978 , pp. 82 a 84.

${ }^{33}$ López Calera, N. M ${ }^{\mathrm{a}}$. Sobre el alcance teórico del uso alternativo del Derecho, en el vol. cit., "Sobre el uso alternativo del Derecho", pp. 25, 26 y 29. 
vols. Ed. al cuidado de P. Barcellona, Ed. Laterza, RomaBari, 1973, y El Estado y los juristas, (trad. esp. de J. R. Capella, Ed. Fontanella, Barcelona, 1976) ${ }^{34}$.

El mejor conocimiento de la significación y alcance de este movimiento exige la consideración de sus fines y de sus medios.

\section{B) Los fines}

El "uso alternativo del Derecho" constituye un fruto característico del pensamiento neomarxista que hace suyos y se nutre de la doctrina y del método del materialismo histórico ${ }^{35}$.

Coherentemente con ello dicho movimiento se propone fundamentalmente dos cosas:

a) La erosión y derrocamiento de la sociedad burguesa capitalista cuyas contradicciones internas en el sistema de producción han sumido a sus instituciones en una crisis profunda, incapacitándola para resolver esas contradicciones así como para satisfacer las necesidades y demandas que una nueva sociedad emergente exige. Las contradicciones internas de la sociedad capitalista (se teoriza) la condenan irremisiblemente a su extinción, postulándose a este respecto que las demandas y el empuje de las masas populares sea aprovechado, guiado e impulsado por las fuerzas "progresistas", para llevar a cabo, de forma definitiva, la transformación estructural que permita el tránsito de la sociedad burguesa actual hacia un sistema social cualitativamente superior; esto es, hacia una sociedad sin clases, democrática y socialista $^{36}$.

34 Ibíd. pp. 11 y 16; ANDRÉS IBÁŃEZ, P. Op. cit., pp. 67 y 68 y SAAVEDRA LÓPEZ, M. Interpretación jurídica y uso alternativo del Derecho, en el vol. cit., "Sobre el uso alternativo del Derecho", p. 39.

35 Ibíd. SAAVEDRA LÓPEZ, M. p. 42.

${ }^{36}$ Ibíd. pp. 35 a 37. 
b) La segunda tarea que se proponen los defensores del uso alternativo del Derecho es la de alcanzar, a través del mencionado cambio social, la "emancipación" de las "clases trabajadoras", oprimidas por el capitalismo. En este sentido ha subrayado L. Ferrajoli que el "uso alternativo del Derecho", en su esencia, no es más que la continuación de la "lucha de clases" por otros medios ${ }^{37}$.

Reitera en este sentido López Calera, resumiendo la filosofía y la estrategia del movimiento que estudiamos, que, en la sociedad actual, "la lucha de clases no pasa sólo por la conquista inmediata e incluso violenta de los aparatos de poder del Estado, ni por el asalto a los palacios de invierno, sino que pasa ante todo por el aprovechamiento de todos los resquicios que dejan los sistemas políticos y jurídicos de las democracias burguesas" 38 .

Resumiendo: La situación histórica presente y las condiciones en que se gestó el movimiento del "uso alternativo del Derecho" - a las cuales ya nos hemos referido- hacen que, a "medio plazo", los seguidores de dicha teoría, para alcanzar sus fines últimos, no preconicen la praxis revolucionaria (la Revolución) — praxis difícil o inviable en el seno de una sociedad capitalista avanzada, de una sociedad burguesa satisfecha de sí misma que se autocalifica de sociedad desarrollada, de consumo y de bienestarsino el aprovechamiento de los medios que brinda la propia sociedad burguesa (su sistema político y jurídico) para continuar la "lucha de clases" por otros procedimientos subrepticios, silenciosos y que guardan toda la apariencia de la legalidad. Se trata de erosionar la estructura social y política del denominado orden burgués, y de quebrantarla e incluso subvertirla, invocando los pertinentes principios constitucionales (las famosas contradicciones internas del sistema) del propio orden que se pretende destruir ${ }^{39}$.

37 LÓPez CALERA, N.Mํ. Op. cit., pp. 18, 29 y 30; ANDRÉs IBÁÑEZ, P. Op. cit., p. 72.

38 Op. cit., p. 29.

39 ANDRÉS IbÁÑEZ, P. Op. cit., pp. 64 y 65. 
A través de esa praxis jurídica de "ruptura" se pretende abrir nuevas vías de participación y actuación políticas y jurídicas y de crear las condiciones adecuadas para que, a medio o largo plazo, se haga posible dar el "salto cualitativo" que lleve al establecimiento de una sociedad sin clases (sin explotadores y explotados); de una sociedad socialista, libre, igualitaria y democrática ${ }^{40}$.

\section{C) El método}

Los teóricos del "uso alternativo del Derecho" se han cuidado de aclarar y precisar dos cosas:

- Primera: Que no se trata de un uso evolutivo del Derecho, orientado a la adaptación del Derecho burgués a las necesidades de una sociedad capitalista en transformación, neutralizando sus contradicciones y disfunciones.

- Segunda: De lo que se trata es de un efectivo uso alternativo del Derecho que implica "un cambio en la orientación básica de la regulación jurídica"41. Ello no supone desplazar al legislador ni liberar al poder judicial de su deber de sumisión y obediencia al Derecho, sino de promover una política judicial permitida por las posibilidades que ofrece el mismo ordenamiento jurídico (incluidas por supuesto sus antinomias y lagunas jurídicas) que provoque en la vida de las sociedades capitalistas en crisis efectos progresivos en el plano de la superestructura jurídica, superando las tensiones y contradicciones de dichas sociedades y favoreciendo los intereses de los grupos no dominantes en las mismas, haciendo así posible la liberación de las clases oprimidas ${ }^{42}$.

La puesta en práctica del uso alternativo del Derecho exige, según sus teóricos y defensores, un riguroso proceso

${ }^{40}$ López Calera, N. Mª . Op. cit., pp. 16, 17, 18, 28 y 29; SaAvedra LóPez, M. Op. cit., pp. 55 y 57 a 59 .

${ }^{41}$ SAAVEDRa LóPez, M. Op. cit., p. 53.

${ }^{42}$ Ibíd. pp. 35 y 40 a 43. 
metódico que, reduciendo la complejidad del mismo, puede simplificarse en dos momentos: El primero, de naturaleza intelectual y crítica y, el segundo, de carácter puramente metodológico y práctico.

\section{a) Momento intelectual: Conocimiento y crítica del Derecho burgués}

Consiste dicho momento en el estudio y análisis crítico del orden jurídico-político burgués para desvelar y poner de relieve sus insuficiencias y contradicciones, así como la falsedad de su concepciones teóricas y prácticas. En este sentido el "uso alternativo del Derecho" comprende las siguientes tareas:

\section{1ํ. Crítica del Estado liberal de Derecho}

Ante los cambios experimentados por la sociedad en el último siglo se subraya y se somete a crítica las carencias $y$ limitaciones del Estado liberal de Derecho, incapaz de resolver las tensiones y contradicciones de la sociedad capitalista y de satisfacer las demandas de justicia, las exigencias contenidas en los derechos de las masas populares y trabajadoras ${ }^{43}$.

Se denuncia asimismo la quiebra del principio liberal de la distinción entre Estado y sociedad civil y del principio de división de poderes, ante la invasión, por parte del Estado de ámbitos y competencias pertenecientes a la sociedad civil, y la conversión de la judicatura en un instrumento ideológico del poder político y de los intereses de la clase dominante para llevar a cabo y legitimar la represión $^{44}$ (S. Senese).

$2^{\text {o }}$. Crítica de la concepción burguesa del Derecho

Piensan también los partidarios del "uso alternativo del Derecho" que el Derecho vigente en las democracias bur-

43 López Calera, N.Ma. Op. cit., p. 12.

44 ANDRÉs IbáÑEZ, P. Op. cit., pp. 69 a 71. 
guesas, fruto de los procesos de codificación impulsados fundamentalmente por el movimiento liberal, no constituye un instrumento puramente racional e ideológicamente neutro sino un resultado de la "lucha de clases" (L. Basso $)^{45}$ y, en cuanto tal, la expresión de los intereses de la clase dominante ${ }^{46}$. Por esta razón el Derecho de la sociedad burguesa no es un instrumento ético al servicio de la justicia y de la liberación humana sino un aparato técnicopolítico de la dominación de clase ${ }^{47}$ (P. Barcellona).

Frente a la ingenua creencia de los ideólogos liberales el Derecho resultante de la codificación no constituyó un sistema de normas unitarios, coherente y pleno ${ }^{48}$, sino un corpus de normas aquejado de imperfecciones técnicas (ambigüedades del lenguaje, antinomias, lagunas jurídicas, etc. ${ }^{49}$ y materiales. Materiales en la medida en que sus contenidos normativos no fueron más que la consagración de las exigencias e intereses de las clases burguesas.

\section{3ํ․ Crítica de la Ciencia jurídica dogmática}

Igual que el Derecho de la sociedad burguesa la Ciencia jurídica dogmática construida sobre el mismo está muy lejos de reunir las notas de racionalidad, objetividad y apoliticidad exigidas por el saber científico. Las tareas metódicas a través de las cuales se articula la Ciencia jurídica (sistematización, interpretación y construcción de conceptos) no son, como pretende hacérsenos creer, asépticas, políticamente neutras, sino que están ideológicamente contaminadas. Por ello la Ciencia jurídica tiene un carácter radicalmente político ${ }^{50}$.

45 Ibíd. pp. 63 y 64; SAAVEdRa LóPez, M. Op. cit., p. 55.

46 LóPez Calera, N.M ${ }^{\mathrm{a}}$. Op. cit., p. 12.

47 Ibíd. pp. 16 y 20.

48 BobBio, N. Il positivismo giuridico, (Lezioni di Filosofia del Diritto raccolte dal Dr. Nello Morra. Anno Accademico 1960-1961. Cooperativa Libraria Universitaria Torinese - Editrice, Torino, s/a. pp. 253 a 275; Teoría dell'ordinamento giuridico, G. Giappichelli, Editore, Torino, 1960, pp. 25 y ss., 69 y ss., $125 \mathrm{y}$ ss.

49 ANDRÉs IbÁÑEz, P. Op. cit., pp. 78 a 81; LóPez CALERA, N.M ${ }^{\text {a }}$ Op. cit., p. 28.

${ }^{50}$ LóPez Calera, N.M ${ }^{\mathrm{a}}$. Op. cit., p. 16; SAavedRa LóPez, M. Op. cit., pp. 49 y ss. 
Se trata de un instrumento encaminado al conocimiento y a la aplicación del Derecho, en el que ve un dogma social, y que induce a la rutina y al afianzamiento del sistema, a la protección de la clase dominante. El estudio dogmático del Derecho y su praxis rutinaria conducen a una esclerosis del pensamiento jurídico que dificulta el acceso a la reflexión crítica y bloquea todo proceso de renovación de las ideas y de los juicios de valor en el jurista ${ }^{51}$.

\section{$4^{\circ}$. Crítica del método y de la praxis judicial tradicional}

La doctrina del "uso alternativo del Derecho" denuncia ante todo, por ideológico y utópico, el principio de la condición independiente y apolítica de la judicatura en el Estado burgués. En dicho Estado, radicada la Administración de justicia en un ministerio (Ministerio de Justicia), la magistratura aparece vinculada al poder ejecutivo, haciendo posible y legítima la represión del Estado, de acuerdo con los intereses de la clase dominante ${ }^{52}$.

A este respecto los teóricos del "uso alternativo del Derecho" denuncian y critican, como construcciones puramente ideológicos que falsean y ocultan la realidad de las cosas, una serie de principios o dogmas de la doctrina tradicional y burguesa del Derecho.

Entre ellos destacan:

1. La idea o principio de la independencia, imparcialidad y apoliticidad de la actividad judicial ${ }^{53}$ (L. Ferrajoli).

2. La consideración de la interpretación y aplicación del Derecho como una tarea puramente científica. Dicha idea es el resultado de la visión ideológica que los juristas burgueses tuvieron del Derecho resultante de la codificación. Se trata de la idea positivista de que el Derecho constituye un sistema normativo caracterizado por las notas de unidad, coherencia y plenitud, y

51 SAaVedra LóPez, M. Op. cit., pp. 49, 50y 51; ANDRÉs IbáŃEZ, P. Op. cit., pp. 86 a 88.

${ }^{52}$ ANDRÉS IBÁÑEZ, P. Op. cit., pp. 71, 73 y 74.

${ }^{53}$ LóPez CAlera, N. Mª . Op. cit., p. 17; ANDRÉs IBÁÑEz, P. Op. cit., p. 71. 
que la tarea de su aplicación se resuelve en un proceso puramente técnico, neutro, constituido por la interpretación de la norma y la subsunción mecánica de los hechos en el supuesto de hecho de la misma. La solución se obtiene así de forma puramente lógica mediante un razonamiento claro y seguro de estructura silogística ${ }^{54}$. La consideración de la interpretación y aplicación del Derecho como una actividad puramente lógica, científica, "constituye -explica M. Saavedra- la base de sustentación de la ideología de la independencia judicial, de la autonomía de la Ciencia jurídica (y) de la separación entre el Derecho y la política o entre legalidad y justicia" 55 .

3. La interpretación y la aplicación del Derecho, tal como se han venido desarrollando en el seno de la sociedad y del Estado liberal burgués, supone - según la teoría del "uso alternativo del Derecho"una indudable tarea política encubierta por el velo ideológico de la cientificidad, la neutralidad y la independencia de la judicatura.

La administración de justicia en el Estado liberal de Derecho ha constituido una específica actividad política orientada a la defensa, mantenimiento y consolidación del sistema político-social. Con ello la magistratura ha contribuido decisivamente a asegurar y a perpetuar la hegemonía de la clase dominante y la injusticia ${ }^{56}$.

b) Momento práctico: Legitimidad y posibilidad de una praxis jurídica alternativa

1‥ Justificación del "uso alternativo del Derecho"

Esta corriente doctrinal surge como consecuencia de la nueva situación creada en el "mundo del trabajo" como

54 ANDRÉS IBÁŃEZ, P. Op. cit., pp. 78 y 79.

55 Op. cit., p. 45.

56 López Calera, N. M ${ }^{\mathrm{a}}$. Op. cit., p. 12 a 15, 17, 18 y 28; SAAvedra LóPez, M. Op. cit., pp. 37, 38, 43 у 44 a 46 . 
consecuencia del desarrollo y expansión de la sociedad capitalista que ha generado tensiones, conflictos y nuevas necesidades en las clases trabajadoras que el viejo Estado de Derecho, de cuño liberal, prisionero de sus propios principios y dogmas, no puede resolver. Y ello — se diceaunque ha invadido, abusando de sus competencias, ámbitos de la vida social que no le corresponden, conculcando así principios y dogmas fundamentales sobre los que se asienta y fundamenta su propia legitimidad ${ }^{57}$.

Otra razón que impulsa y legitima el "uso alternativo del Derecho" es, indica P. Andrés Ibáñez, la penosa y contradictoria imagen que ofrece un Poder judicial, que se presenta como "independiente y apolítico", y que aparece articulado como una pieza más de la maquinaria del Estado, implicada en la dinámica del poder político, prestando cobertura y legitimación a sus practicas represivas ${ }^{58}$.

\section{$2^{\text {o }}$. Posibilidad de una praxis jurídica alternativa}

Ante todo debe recordarse que el "uso alternativo del Derecho" hizo su presentación como un movimiento de "juristas comprometidos", "progresistas", cuyo objetivo inmediato no era hacer la "revolución" sino sólo impulsar la erosión y el resquebrajamiento del orden jurídico-político de la sociedad capitalista. Mediante ese proceso de desgaste y fractura del orden jurídico-político se busca -indican sus teóricos - una ampliación de los espacios de libertad real de las clases oprimidas y, al mismo tiempo, ir creando las condiciones adecuadas para que, en su momento, pueda darse el "salto cualitativo" que va desde un orden social burgués y represivo hasta una sociedad socialista, auténticamente libre, igualitaria y realmente democrática ${ }^{59}$.

Los teóricos del "uso alternativo del Derecho" - que como se ha indicado es un movimiento silencioso, cauteloso, precavido - entienden que de inmediato, para alcanzar

57 ANDRÉs IBÁÑEz, P. Op. cit., pp. 70.

58 Ibíd. pp. 70, 71, 72 y ss.

59 SaAvedra López, M. Op. cit., p. 59. 
la mencionada meta, no es necesario modificar las normas jurídicas sino que basta, manteniendo el texto de las mismas, con alterar su alcance y significación mediante una "interpretación alternativa" de carácter "progresista"60.

¿Qué significa ello? Ante todo, según los teóricos del movimiento, reconocer el carácter creativo y voluntarista (no meramente lógico-mecanicista) del proceso de aplicación del Derecho. Dicho proceso supone, según la doctrina que estamos describiendo, poner de relieve tanto los defectos y limitaciones del Derecho positivo (ambigüo, contradictorio, incompleto, inseguro...) como la insuficiencia y parcialidad de la jurisprudencia tradicional plegada a los intereses del poder y de las clases dominantes, y carente de espíritu y reflexión crítica e innovadora ${ }^{61}$.

El contraste con la jurisprudencia tradicional permite destacar con más nitidez y precisión el carácter creativo y voluntarista de la función de aplicar el Derecho según la doctrina que estamos exponiendo. El carácter creativo y voluntarista de dicha función se pone de manifiesto básicamente en dos momentos: De un lado, en la construcción y fijación definitiva de los hechos sobre los que hay que decidir; de otro lado, en la selección e interpretación de las normas en las que aquéllos se han de subsumir, de manera que el proceso conduzca al resultado previsto y deseado ${ }^{62}$.

60 ANDRÉs IBÁÑEZ, P. Op. cit., pp. 82 a 84.

61 Ibíd. pp. 85 a 88. A este respecto escribe P. ANDRÉs IBÁÑEZ: "El mundo de los jueces ha permanecido durante decenios, pudiera decirse, ensimismado e inmerso en la dócil aplicación de todo lo que le llegaba formalmente sancionado como Derecho. Y, aparte trabajos de valor eminentemente práctico, casi siempre centrados en comentarios, exposiciones o estudios de jurisprudencia en una línea normalmente inalterada de fidelidad a los criterios del vértice, en la proyección doctrinal de los profesionales de la justicia ha estado ausente toda referencia crítica — que no fuera de matiz puramente técnico — a la legalidad vigente o a la actual estructuración y planteamiento de la función. Por el contrario, no han faltado publicaciones como las de Ríos Sarmiento, Fernández Nicolás, Rull Villar, exponentes de una suerte de literatura apologética, laudatoria y autocomplaciente, que asimismo puede rastrearse en un sinnúmero de discursos". $O p$. cit., pp. 87 y 88.

62 SAAVEdRA López, M. Op. cit., pp. 46 a 48. Nuestro D. Francisco de Quevedo y Villegas, ingenio agudo donde los haya, ya se había percatado de este modo de proceder de determinados juristas que prescinden, en la interpretación de la 
Ese proceso creativo y voluntarista en la aplicación del Derecho es posible y necesario - explica la doctrina del uso alternativo del Derecho- por dos motivos fundamentales:

- Primero: Por la necesidad (mandato legal) de tener en cuenta, en la aplicación del Derecho, los principios generales del Derecho, la equidad y la analogía ${ }^{63}$.

- Segundo: Por la existencia en el Derecho positivo de cláusulas y términos generales y ambiguos que precisan de concreción y la existencia de antinomias y lagunas jurídicas. Las tareas de concreción de los términos generales y ambiguos, de solución de las antinomias (en especial las "antinomias de principio") y de integración de las lagunas jurídicas que han de ser llevadas a cabo por el intérprete abren ante el mismo una pluralidad de opciones. Estas van desde la posibilidad de plegarse a los intereses del poder y de la clase dominante hasta la de separarse de esa línea promoviendo una interpretación del Derecho innovadora, progresista y democrática —orientada e impulsada por las convicciones ideológicas y políticas del intérprete, que así penetran en el Derecho-, en contra de los intereses de las clases dominantes y a favor de las clases oprimidas ${ }^{64}$.

ley, de los criterios histórico-genético y teleológico, entre otros, y que la doctrina del "uso alternativo del Derecho" parece elevar a paradigma. Escribe Quevedo: "Habrá más pleitos, no porque habrá más razón, sino porque habrá más leyes. Con nuestro estilo tenemos la paz que habemos menester, y los demás, la guerra que nosotros queremos que tengan; las leyes por sí buenas son y justificadas; más habiendo legistas todas son tontas y sin entendimiento. Esto no se puede negar, pues los mismos jurisprudentes lo confiesan todas las veces que dan a la ley el entendimiento que quieren, presuponiendo que ella por sí no lo tiene. No hay juez que no afirme que el entendimiento de la ley es el suyo, y con decir que se le dan, supone que no le tiene. Yo, renegado soy, cristiano fui, y depongo de vista que no hay ley civil ni criminal que no tenga tantos entendimientos como letrados, y jueces como glosadores y comentadores, y a falta de entendimiento que la achacan, le falta el que tiene y queda mentecata". Francisco de QuEvEDo, La hora de todos y la fortuna con seso, en "Los Sueños", Círculo de Amigos de la Historia, Impreso y encuadernado por "Amigos do Livro", Editores, Camarate (Portugal), s/a. p. 263. Véanse también las pp. 65, 160 a 162, 224 y ss., 262 y ss.

63 SaAvedra López, M. Op. cit., p. 49.

${ }^{64}$ Ibíd. pp. 49, 58 y 59; ANDRÉs IbÁÑez, P. Op. cit., pp. 66 y 80 a 84. 


\section{D) Hacia una nueva concepción del mundo jurídico}

Los postulados tanto teóricos como prácticos del uso alternativo del Derecho apuntan, como consecuencia de su desarrollo, hacia una nueva concepción del mundo jurídico en la que cabe resaltar la reducción del Derecho a un instrumento puramente técnico al servicio de la praxis ideológica. Los temas más relevantes de esta teoría jurídica son los siguientes:

\section{a) Una nueva concepción del Derecho}

Se trata, indican los seguidores y expositores del nuevo movimiento doctrinal, de "una concepción no mecanicista, no determinista del Derecho, inscrita en una adecuada relación base-superestructura". Se trata, se dice, de "conferir al Derecho un status de autonomía y a la práctica jurídica un lugar adecuado en el conjunto de relaciones estructurales. (De) una concepción del Derecho y del Estado, en el interior de la teoría marxista del Estado, que se distancie definitivamente de la concepción del Derecho como engaño de las clases dominadas y del Estado como instrumento de represión en manos de las clases dominantes" ${ }^{\prime 65}$.

\section{b) Una nueva concepción de la Ciencia jurídica}

Partiendo del reconocimiento y la denuncia del carácter ideológico-político de la Ciencia jurídica (dogmática) tradicional $^{66}$, la tarea consiste en buscar y construir otro "modelo" de Ciencia jurídica, lo cual resulta posible partiendo de otros supuestos. Entre esos supuestos se encuentran:

a) La imposibilidad de desligar la teoría de la práctica. En este sentido advierte M. Saavedra: "No se puede perder de vista que normas e institutos jurídicos tienen unos determinados efectos prácticos, que cumplen una determinada función económica, social y

65 SAavedra López, M. Op. cit., p. 43.

${ }^{66}$ Ibíd. p. 49. 
política. Hay que analizar, por tanto, esa conexión orgánica y establecer a partir de ahí las necesidades, la dirección y los límites de la alternativa"67.

b) La existencia de valores e instancias extrínsecas al sistema jurídico pero integradas en el contexto social, histórico, en el que vive, piensa y trabaja el jurista. A este respecto, escribe M. Saavedra, que la referencia a "instancias extrínsecas al sistema, es decir, (a) juicios de valor ligados al contexto del agente jurídico permiten una orientación divergente de la dogmática y de la interpretación del caso concreto"68.

Se trataría, entonces, continúa diciendo M. Saavedra, de construir "una Ciencia del Derecho que no se resuelva en abstracciones intrasistemáticas o análisis formales, sino que recupere la relación existente entre normas jurídicas y estructuras sociales. Una Ciencia del Derecho que, en lugar de reducirse a efectuar síntesis generalizadoras del material jurídico, tienda a elaborar críticamente categorías que permitan una explicación adecuada de los vínculos genéticos y funcionales que unen la superestructura de los códigos y de los conceptos jurídicos a la totalidad social; que analice la función de las distintas instituciones jurídicas «en relación con la distribución real de poderes de la sociedad». Sería — concluye diciendo- una Ciencia jurídica «alternativa» al servicio de una también «alternativa» práctica emancipadora" 69 .

La elaboración de esa nueva Ciencia jurídica viene posibilitada y exigida por una conjunción o pinza integrada, en referencia al ordenamiento jurídico, por factores intrasistemáticos y extrasistemáticos. Se trata de las posibilidades y exigencias constituidas tanto por los defectos técnicos ya indicados del propio sistema jurídico (ambigüedad, antinomias, lagunas jurídicas) (factores intrasistemáticos), como por la acción, por la presión política y social, de las fuerzas populares y democráticas, cuyos in-

67 Ibíd. p. 53.

68 Ibíd. p. 50.

${ }^{69}$ Ibíd. pp. 53 y 54 . Véanse también las pp. 55 y 56. 
tereses y derechos habían sido olvidados y excluidos por parte del Derecho y de la Ciencia jurídica burguesas ${ }^{70}$ (factores extrínsecos).

\section{c) Una nueva concepción del método jurídico}

La nueva concepción del Derecho y de la Ciencia del mismo implican una nueva concepción del método jurídico: Un método jurídico alternativo.

Junto con la negación, desde el punto de vista ideológico, del carácter científico y neutro de la Ciencia y de la praxis jurídicas ${ }^{71}$, el jurista se encuentra, por otro lado, como ya se ha indicado, con la naturaleza ambigüa, contradictoria, incompleta... de los textos legales. Ello supone, como apunta S. Senese, que "la mayor parte de las normas consienten más de una interpretación, jurídicamente correcta, por lo que es preciso hacer siempre una elección que no puede ser operada con criterios jurídicos tan sólo"72.

Esta circunstancia coloca al jurista, a la hora de interpretar y aplicar el Derecho, ante un dilema, en especial en

70 En este sentido escribe M. Saavedra López en relación con la posibilidad y necesidad de la nueva Ciencia jurídica: "Las medidas de posibilidad vendrán dadas por el mismo sistema, que ya no puede ser visto como un conjunto coherente, sino contradictorio, lleno de fracturas, con puntos de apoyo suficientes para elaborar construcciones jurídicas que promuevan la realización de intereses excluidos. (factores intrasistemáticos) (...) Habrá que efectuar, por tanto —añade Saavedra-, un estudio de las posibilidades teóricas que ofrece cada sistema jurídico en orden a su utilización alternativa. Debemos recordar, sin embargo, que las medidas de posibilidad no vienen dadas solamente por el mismo sistema ni tampoco por la disponibilidad de operadores dispuestos a utilizarlo alternativamente. Antes que eso están los hechos: «la presión política y social» de las fuerzas empeñadas en una democratización real del derecho y de la práctica jurídica; y su propia práctica, es decir, el grado de desarrollo alcanzado por una acción divergente que intenta abrirse paso a través de los frenos institucionales y que impone su presencia al margen y aun en contra de la legalidad reconocida. Se trata, pues, de un "proceso de convergencia» de la práctica efectiva de las fuerzas democráticas y de los puntos de apoyo jurídicos ofrecidos por el mismo sistema, aunque sea de forma larvada o poco institucionalizada". (factores extrasistemáticos). Op. cit., pp. 54 y 55 .

${ }^{71}$ Ibíd. p. 51.

72 ANDRÉs IBÁÑEZ, P. Op. cit., p. 68. 
el supuesto de las antinomias de principio o ideológicas. Básicamente, ante esta situación, el jurista puede hacer dos cosas:

- Primera: Seguir el punto de vista de la jurisprudencia tradicional interpretando y aplicando la ley de acuerdo con los valores políticos o ideológicos dominantes, lo cual equivale, según la doctrina del "uso alternativo del Derecho", a inscribirse y adherirse a la misma lógica del poder establecido, contribuyendo a legitimar su función represiva.

- Segunda: Intentar, por el contrario, una jurisprudencia alternativa que, dentro de los cauces acotados por la legalidad vigente, le lleve al jurista a elegir — dentro de las interpretaciones posibles y de acuerdo con sus propias ideas y creencias (el proceso interpretativo es constitutivamente subjetivo) - una interpretación distinta e incluso opuesta a la tradicional, de carácter innovador y progresista ${ }^{73}$; una interpretación "que pueda presentar la promoción de intereses más justos o más ampliamente compartidos"74.

La interpretación alternativa del Derecho supone así, por su carácter progresista, escribe P. Andrés ibáñez, "una actitud decididamente orientada por vía interpretativa a la ampliación de los posibles espacios democráticos del or-

${ }^{73}$ Ibíd. pp. 81 y 82.

${ }^{74}$ SAAVEDRA LÓPEZ, M. Op. cit., p. 55. Véanse las pp. 66 y 67 . A este respecto, y en relación con el ordenamiento jurídico italiano, escribe P. Andrés Ibáñez: "La antinomia que hemos visto se da entre la Constitución italiana y las leyes fascistas (Código Penal, Ley de Procedimiento Penal, Ley de Seguridad Pública, Reglamento Penitenciario...), no es tanto de carácter técnico-jurídico como específicamente política, a nivel de principios informadores, en cuanto lo que verdaderamente se enfrenta son dos modos diversos de concebir la organización política de la sociedad, que se hacen explícitos en el nivel jurídico. Así, en el marco de un mismo ordenamiento conviven dos instancias axiológicas claramente antagónicas que constituyen sin duda puntos de referencia alternativos para la concreta actividad del intérprete. Éste deberá ahora reconocerse inexcusablemente como portador de una determinada de entre las varias posibles políticas del Derecho. Derecho que podrá — dentro de ciertos límites, desde luego, pero no sin operatividad - por su mediación dirigirse tendencialmente hacia la modificación o simplemente (como era lo habitual) la conservación tal cual de lo que existe”. Op. cit., p. 66. 
denamiento jurídico, que se proyecta críticamente sobre el actual modo de inserción del Poder judicial en el aparato de Estado y se articula en una serie abierta de proposiciones para la reforma orgánica y la actuación concreta". Y añade Andrés Ibáñez: "El «uso alternativo del Derecho" aparece conectado, en suma, a una propuesta alternativa de organización de la justicia y ha sido asumido como planteamiento y actitud por un sector de la magistratura italiana, al que se debe en gran medida el interés público y la difusión que el tema ha tenido en Italia y fuera de Italia"75 (especialmente en España).

El "uso alternativo del Derecho", explica P. Andrés Ibáñez, debe elegir siempre, en la interpretación de la norma, la opción más progresista y democrática. Para ello, añade dicho autor, debe convertir los valores y principios de signo igualitario y democrático, que con frecuencia $-\mathrm{y}$ con fines puramente retóricos e incluso demagógicos- se incorporan a los preámbulos y exposiciones de motivos de las normas que integran los modernos ordenamientos jurídicos, "en una plataforma desde la que (sea exigido) entender e interpretar el resto de las normas" del sistema jurídico ${ }^{76}$.

El "uso alternativo del Derecho" implica también, por su propia dinámica, un cambio en la imagen y en la función del juez tradicional. El juez debe abandonar la falsa pretensión de "neutralidad e independencia en un contexto plagado de contradicciones inherentes al sistema" 77 , lo cual, como ha denunciado Ferrajoli, supone ya una opción política a favor del "statu quo" existente y de los intereses del grupo o grupos dominantes ${ }^{78}$. El "uso alternativo del Derecho" exige, por parte del juez, indica M. Saavedra, el abandono del estatuto de neutralidad política y "el compromiso y la toma de partido: la integración social de la función judicial y su puesta al servicio de la liberación humana"79.

75 Ibíd. p. 67.

76 Ibíd. p. 84. Véanse también las pp. 81 y 82.

77 SAavedra López, M. Op. cit., p. 38.

78 Ibíd. p. 52.

79 Ibíd. p. 38. Véase también ANDRÉs IBÁÑEz, P. Op. cit., pp. 81 a 83. 


\section{E) Resultado}

La teoría marxista del Derecho se ha desarrollado, a lo largo del tiempo, de forma zigzageante ajustándose a las circunstancias y exigencias de cada momento.

Desde la perspectiva de nuestro estudio cabe afirmar que el pensamiento marxista ha visto siempre en el Derecho - y junto con él, en la Ciencia y en el método jurídicos- un instrumento técnico de organización, dominación y control social. Y ello es válido - hay que aclarar- para cualquier tipo de sociedad: Tanto para la sociedad burguesa - como denuncia expresamente el marxismo- como para las sociedades donde ha triunfado la Revolución y se ha instaurado el "socialismo real". En las sociedades burguesas, y mediante el Derecho burgués, la clase dominante es la clase capitalista; en las sociedades de "socialismo real", dotadas de una "legalidad socialista", no gobierna en realidad el pueblo sino una "nueva clase dominante" constituida por las élites del Partido comunista.

Lo que ha preocupado obsesivamente al pensamiento neomarxista no ha sido la dictadura impuesta y evidente en los países del "socialismo real" — que nunca o casi nunca ha sido reconocida y siempre justificada - sino la opresión (supuesta en muchos casos) de que son objeto las clases trabajadoras en el seno de la sociedad burguesa y capitalista, en donde el Derecho (el Derecho burgués), continúa siendo un instrumento técnico de sumisión y opresión, desprovisto de toda dignidad ética, en manos de las clases burguesas y explotadoras.

Desde estos supuestos, y favorecida por clima creado por el positivismo jurídico y el relativismo imperantes, la doctrina del "uso alternativo del Derecho", muy en boga en los años setenta y ochenta del S. XX, debe conceptuarse como una corriente de pensamiento puramente "ideológica" —no científica - que pretende llevar a cabo la transformación del Derecho, de la Ciencia y la metodología jurídicas en un instrumento técnico de lucha al servicio de la ideología marxista, denominada ahora con terminología más suave y presentable como ideario o ideología "progresista". 
Se trata, en definitiva, de la conversión del Derecho y del pensamiento jurídico en un arma política, eficaz, silenciosa y con visos de respetabilidad, para la consecución de los fines del marxismo. Dichos fines no han sido ni son otros que la desarticulación y erradicación de la sociedad liberal burguesa y la construcción en su mismo solar, mediante la contribución técnica del Derecho y los juristas, de una nueva sociedad socialista que se presenta - sin ningún fuste, sin una fundamentación seria, coherente, rigurosa y viable - como el modelo de la única sociedad auténticamente libre, igualitaria, justa y democrática.

\section{LA CONCEPCIÓN DEL DERECHO COMO INSTRUMENTO TÉCNICO EN LAS DOCTRINAS CIENTÍFICO-JURÍDICAS}

\section{El utilitarismo jurídico de R. Von Ihering}

Posíblemente sea Ihering, en la segunda etapa de su pensamiento, el máximo exponente del positivismo y del utilitarismo jurídicos, que desemboca en la concepción del Derecho como un sistema de reglas técnicas de origen estatal, garantizadas por la fuerza (coacción).

La importancia de Ihering para el pensamiento jurídico y la difusión que ha alcanzado el conocimiento de su doctrina nos permite, al objeto de nuestro estudio, comprimir la exposición de sus ideas en un sencillo esquema articulado en tres puntos fundamentales: Su concepción de la Sociedad, del Estado y del Derecho.

\section{A) Hombre y Sociedad}

Ihering parte del supuesto de la situación del hombre, en cuanto ser libre, en el mundo ${ }^{80}$. Dicha libertad no está sujeta a la "ley de la causalidad" sino a la "ley del propósito", en virtud de la cual la voluntad es movida, impulsada

${ }^{80}$ IHERING, R. v. El fin en el Derecho, trad. esp. Editorial Heliasta, Buenos Aires, 1978, pp. 35 y ss. 
por la necesidad de buscar, elegir y conseguir los bienes necesarios para la satisfacción de sus necesidades ${ }^{81}$.

Como el individuo no está solo en el mundo sino que coexiste con otros individuos surge el problema, la necesidad, de alcanzar lo que Ihering denomina "coincidencia de propósitos"; esto es, la armonización de los "intereses egoístas" de cada individuo con los "intereses de la colectividad". Dicho propósito se alcanza en la sociedad en la cual aparece ya el fenómeno de la coacción ${ }^{82}$.

La sociedad no es una mera "suma de individuos" sino una "unión de personas" que se han organizado para alcanzar una finalidad común ${ }^{83}$. La sociedad supone así una "cooperación" para lograr fines comunes, "cooperación" que, en virtud de su específica organización, hace posible una reciprocidad de efectos, de manera que al obrar cada uno de sus miembros en beneficio de los demás lo hace también para sí mismo y al actuar en beneficio propio ese beneficio alcanza también a los demás.

Ihering entiende que la sociedad y la cooperación que ella implica para lograr un fin común no es algo que se produzca de forma natural y espontánea sino en virtud de las reglas de conducta (Derecho) que establece el Estado y a la organización de la coacción que ello implica ${ }^{84}$.

\section{B) El Estado}

La sociedad representa un conjunto o tejido de "propósitos organizados" que se hace patente en las múltiples asociaciones que la integran y que culmina en el Estado. Se trata de un proceso cuyos momentos esenciales son los constituidos por el individuo, la asociación y el Estado ${ }^{85}$. Se trata de un proceso de transición, dirigido por la asociación, entre la forma irregular de la fuerza en el indivi-

\footnotetext{
81 Ibíd. pp. 10 y ss., 35 y ss.

82 Ibíd. p. 145.

83 Ibíd. pp. 47 y ss., 106 y ss., 148 y ss.

84 Ibíd. pp. 145 y ss.

85 Ibíd. pp. 152 y 158.
} 
duo hasta la regularización de la fuerza por el Estado ${ }^{86}$. El Estado constituye un grupo organizado cuya esencia es la fuerza. El Estado es el portador y titular de la fuerza coactiva, organizada y disciplinada, que ejerce en régimen de monopolio absoluto ${ }^{87}$. "El Estado - explica Ihering- es la sociedad usando su poder coactivo; para ejercer este poder (la sociedad) toma la forma de Estado. El Estado es, pues, la forma del ejercicio regulado y asegurado de la fuerza de coacción social; brevemente dicho: (El Estado) es la organización de la coacción social"88, constituyendo la aparición de la coacción social organizada lo que separa la sociedad del Estado.

$\mathrm{Al}$ Estado corresponde pues el monopolio de la coacción, de la fuerza, pero el Estado no debe ejercer esa fuerza de modo caprichoso, arbitrario, sino con el fin de garantizar la unidad, la permanencia y la seguridad de la sociedad ${ }^{89}$. Ello lo consigue mediante la producción y aplicación de las normas coactivas en que consiste el Derecho. El Estado se configura así como la única fuente del Derecho ${ }^{90}$. Según Ihering no hay más Derecho que el Derecho estatal y ese Derecho, creado en régimen de monopolio por el Estado, se constituye, al mismo tiempo, en límite y cauce del poder del Estado. El ejercicio de la fuerza, del poder por parte del Estado no debe incurrir en arbitrariedad ${ }^{91}$.

El Estado, en sus actuaciones, debe estar "subordinado (...) a las leyes por él mismo dictadas"92 y aplicarlas, hacerlas cumplir, mediante sus órganos específicos (jurisdicción y administración) ${ }^{93}$. Por esta razón llega Ihering a afirmar que el Derecho es "el conjunto de normas según las cuales se ejerce en un Estado la coacción"94.

\footnotetext{
86 Ibíd. pp. 48, 145 y ss., 148 y ss.

87 Ibíd. pp. 153 y 156 a 158.

88 Ibíd. p. 153.

89 Ibíd. pp. 204 y 205.

90 Ibíd. pp. 157, 158 y 159.

91 Ibíd. pp. 175 y ss., 183 y ss., 203 y ss.

92 Ibíd. p. 183.

93 Ibíd. pp. 188 y ss., 203.

94 Ibíd. p. 158.
} 


\section{C) El Derecho}

Para Ihering el Derecho no es —explica Battaglia-, una "inconsistente formación irreflexiva, producida por un vago espíritu popular (como creía Savigny y la Escuela Histórica), sino un medio técnico a través del cual la cooperación humana tiende a sus fines de progreso realizándolos"95. El Derecho, resume Ihering, integrado por "el conjunto de normas según las cuales se ejerce en un Estado la coacción" 96 constituye, explica Ihering, "el conjunto de condiciones de vida de la sociedad (tomando esta palabra en su sentido lato) aseguradas por el poder público mediante la coacción externa" 97 .

El Derecho así entendido, en cuanto creación racional y técnica del hombre a través del Estado, tiene una doble finalidad o función:

\section{a) El aseguramiento de la existencia y conservación de la sociedad}

Ello lo hace reconociendo, equilibrando y tutelando los divergentes intereses particulares que luchan entre sí -la lucha, según Ihering, es el resorte que impulsa el desarrollo, la perfección y la realización histórica del Derecho ${ }^{98}$ según el principio de utilidad social, de forma que se consiga alcanzar, en cada momento, un equilibrio o armonía entre el interés individual y el interés social.

b) La promoción del desarrollo y la perfección de la sociedad. Notas del Derecho

El Derecho, en cuanto instrumento técnico, impulsa y hace posible la cooperación humana, atendiendo a sus

95 Battaglia, F. Curso de Filosofía del Derecho, Vol. I, trad. esp. de la $3^{\text {a }}$. Ed. italiana por F. Elías de Tejada y P. Lucas Verdú, Instituto Editorial Reus, Madrid, 1951, p. 339.

${ }^{96}$ IHERING, R. vON. Op. cit., p. 158.

97 Ibíd. p. 245.

98 Ibíd. pp. 41 y ss. Véase también IHeRIng, R. von, La lucha por el Derecho, trad. esp. de A. G. Posada, Editorial Atalaya, Buenos Aires, 1947, pp. 105 y ss. 
necesidades y fines de progreso y promoviendo el desarrollo y la elevación de la vida civil y moral de la socie$\operatorname{dad}^{99}$.

Para concluir, podemos indicar que el Derecho, como instrumento técnico de ordenación, control y perfección social, puede llevar a cabo las indicadas tareas en cuanto aparece constituido por un sistema de normas de comportamiento, de observación necesaria, caracterizadas por las siguientes notas:

$1^{\circ}$. La coercibilidad, como nota esencial constitutiva del Derecho sin el cual el Derecho sería inimaginable. Indica Ihering al respecto: "La coacción ejercida por el Estado constituye el criterio absoluto del Derecho; una regla de Derecho desprovista de coacción jurídica es un contrasentido; es fuego que no quema, una antorcha que no alumbra" 100 .

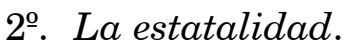

La estatalidad constituye la consecuencia lógica, necesaria, de la concepción del Estado como único detentador del poder de coacción y fuente única del Derecho. No existe más Derecho que el Derecho estatal $^{101}$.

3‥ La generalidad y abstracción.

Ihering piensa que el cumplimiento de la tarea asignada al Derecho exige que las normas de éste consistan en imperativos generales y abstractos que son aquéllos que prescriben "un tipo de acción para todos los casos de cierta especie" ${ }^{102}$.

${ }^{99}$ El fin en el Derecho, cit., ibíd. pp. 204 y ss., 210 y ss., 213; Véase BATTAGLIA, F. Op. cit., p. 339; Bodenheimer, E. Teoría del Derecho, trad. esp. de V. Herrero, $4^{\mathrm{a}}$ reimpresión, Fondo de Cultura Económica, México, 1974, pp. 312 y 314; Friedrich, C. J. La Filosofía del Derecho, trad. esp. de M. Álvarez Franco, 3à . Reimpresión, 1982, p. 227.

100 IHERING, R. vON, El fin en el Derecho, Op. cit., p. 159. Véanse también las pp. 126, 127, 160, 161 y 166.

101 Ibíd. pp. 158 y 166.

${ }^{102}$ Ibíd. p. 164. Véanse las pp. 163 y ss., 167, 171 y ss. 
D) Consideraciones críticas

El pensamiento de Ihering supone un utilitarismo de base relativista. La idea propugnada por Ihering de que el Derecho tiene como misión crear y garantizar las condiciones de la vida social mediante el equilibrio y armonía del interés o utilidad social es algo muy vago y genérico que encalla en un relativismo social, jurídico y político - los intereses son históricamente distintos y mutables- ${ }^{103}$ que, como observa Larenz, "niega el propio valor del Derecho, y lo convierte en juguete de los intereses en cada caso predominantes en la sociedad"104.

\section{El formalismo normativista de H. Kelsen}

\section{A) Meta y supuestos metódicos del pensamiento de Kelsen}

La pretensión de Kelsen de elaborar una teoría autónoma del Derecho (Teoría pura del Derecho) desemboca también en una concepción puramente técnica y coactiva del mismo.

Supuestos metodológicos de esa empresa son:

\section{a) La concepción positivista de la Ciencia}

Dicha concepción aparece fundada en la evidencia lógica (matemática, lógica, ...) y en la experiencia (ciencias de la naturaleza basadas en el principio de causalidad - física, química, etc.-).

b) La distinción entre "ser" (sein) y "deber ser" (sollen)

La distinción neokantiana entre "juicios del ser" (sein), de carácter explicativo, como acontece con las ciencias

103 Ibíd. pp. 214 y 216.

${ }^{104}$ Larenz, K. Metodología de la Ciencia del Derecho, trad. esp. $2^{\mathrm{a}}$ ed. de la 4ª . Ed. alemana de M. Rodríguez Molinero, Ed. Ariel, Barcelona, 1980, p. 70. 
causales, y "juicios del deber ser" (sollen), de significación normativa, propios de las ciencias que tienen por objeto el estudio de las normas (morales, jurídicas, ...): Ciencias normativas ${ }^{105}$.

\section{c) La pureza metódica}

Esto supone la eliminación de la Ciencia jurídica de todo dato de carácter "fáctico" o "metafísico". Para la Ciencia jurídica los contenidos de las normas (éticos, políticos, técnicos...) son irrelevantes. La Ciencia jurídica, depurada de todo contenido (Teoría pura del Derecho) se configura así como una ciencia formal diferenciada de las Ciencias de los hechos (Ciencias de la naturaleza, Sociología, Historia, Psicología...) y de la Metafísica (Ética, Moral, Derecho natural... $)^{106}$.

Se trata (hablamos de la Ciencia jurídica) de una ciencia normativa formal (cuyo objeto no es ya el "ser" (sein) sino las normas ("deber ser", sollen) como categorías formales ${ }^{107}$, lo cual hace de la ciencia jurídica una auténtica "geometría del Derecho" que sólo estudia "formas sin contenido" 108 .

B) Noción del Derecho.

El Derecho como técnica de control social

Desde estos supuestos Kelsen obtiene una concepción del Derecho puramente técnica que irá acentuando dicha significación a lo largo del tiempo.

105 Kelsen, H. Problemas capitales de la Teoría jurídica del Estado, (Desarrollados con base en la doctrina de la proposición jurídica), trad. esp. de la $2^{\mathrm{a}}$. Ed. alemana por W. Roces, Notas, revisión y presentación de U. Schmill, Ed. Porrua, México, 1987, pp. 5 y ss., 54 y ss., 59 y ss.; Teoría Pura del Derecho, (Introducción a la Ciencia del Derecho), trad. esp. de M. Nilve, $30^{a}$ ed., Editorial Universitaria de Buenos Aires, 1994, pp. 24 y ss., 26 y ss., 27 y ss.

106 Kelsen, H. Teoría Pura del Derecho, $1^{\underline{a}}$ ed. cit., pp. 15 y 16.

107 Ibíd. pp. 15, 16, 34 y ss.

108 Problemas capitales..., cit., pp. 79 y 80. 
a) La norma como "mero juicio hipotético"

Inicialmente Kelsen concibe el Derecho como sistema de normas de conducta humana cuya especificidad no radica en los contenidos de los mismos (irrelevantes como se ha indicado ya para el pensamiento jurídico) sin en su forma normativa (lo propio del Derecho es consistir en normas) la cual constituye un "juicio hipotético" (Zurechnung) que vincula a determinados actos una consecuencia o efecto jurídico (si alguien roba "debe ser" castigado). La expresión "debe ser" no tiene aquí un carácter imperativo ni valorativo (ético) sino puramente lógico: Se trata de una forma de pensar que se expresa mediante un "juicio hipotético" (si A, "deber ser" B) en el que se enlazan un "supuesto de hecho" condicionante con una "norma jurídica" por él condicionada, y cuyo "ser", cuya "existencia", consiste en su "validez" (en cuanto contenido de sentido) ${ }^{109}$.

En la medida en que las normas jurídicas (independientes de todo juicio o valor ético) tienen como característica esencial regular la conducta humana vinculando a determinados comportamientos una sanción, el Derecho se configura y reduce a una técnica de ordenación y control social.

b) Distinción entre "norma jurídica" y "regla del Derecho". Carácter imperativo de la norma jurídica

Posteriormente, y como consecuencia de su contacto con la sociología americana, Kelsen revista su doctrina introduciendo en la misma la distinción entre "norma jurídica" (Rechtsnorm) y "regla de Derecho" (Rechtssatz).

La regla de Derecho o enunciado jurídico, según Kelsen, es la proposición que formula la Ciencia jurídica (lenguaje de los juristas) cuando habla de las normas que constituyen su objeto. Las reglas jurídicas, dice Kelsen, son "las

109 Kelsen, H. Teoría Pura del Derecho, $1^{\mathrm{a}}$ ed., cit., pp. 27 y ss., y 35; Problemas capitales... cit., pp. 61 y ss.; ¿Qué es la Teoría Pura del Derecho?, trad. esp. de E. Garzón Valdés, $4^{\mathrm{a}}$ ed. Biblioteca de Ética, Filosofía de Derecho y Política, núm. 11, Distribuciones Fontanara, México, 1995, pp. 15 y ss. 
proposiciones mediante las cuales la Ciencia jurídica describe su objeto"110. Dichas proposiciones, entiende Kelsen, tienen un carácter puramente lógico y se expresan mediante un juicio hipotético ${ }^{111}$.

La norma jurídica (Rechtsnorm) tiene ahora, para Kelsen, un carácter imperativo. Kelsen acoge, en este segundo momento, la teoría imperativa de la norma que inicialmente había sometido a crítica ${ }^{112}$, admitiendo que la norma jurídica "es un acto de voluntad" que puede "presentarse bajo la forma de un imperativo"113. Las normas jurídicas, añade Kelsen "no constituyen proposiciones, esto es, enunciados declarativos sobre un objeto dado al conocimiento. Según su sentido - aclara Kelsen-, son mandamientos y, en cuanto tales, ordenes, imperativos" (que incluyen también permisiones y autorizaciones) ${ }^{114}$.

\section{c) Imperatividad y coactividad de la norma jurídica}

Debe añadirse que en el pensamiento de Kelsen ese imperativo en que consisten las normas jurídicas viene cualificado por su dimensión coactiva lo cual perfila y potencia la concepción kelseniana del Derecho como un instrumen-

110 Teoría Pura del Derecho, $1^{\mathrm{a}}$ ed. cit, p. 46.

111 Ibíd. p. 47. Las proposiciones o enunciados jurídicos, explica Kelsen en la $2^{\underline{a}}$ ed. su Teoría Pura del Derecho, "son proposiciones condicionales que expresan que conforme a un orden jurídico, nacional o internacional, dado al conocimiento jurídico, deben producirse ciertas consecuencias determinadas por ese orden, bajo determinadas condiciones que el orden jurídico determina. Las normas jurídicas no constituyen proposiciones, esto es, enunciados declarativos sobre un objeto dado al conocimiento. Según su sentido, son mandamientos y, en cuanto tales, órdenes imperativos; pero no sólo mandamientos, sino también permisiones y autorizaciones; en ningún caso, empero, pese a lo que a veces se suele afirmar al identificar el Derecho con la Ciencia del Derecho, información instructiva.", Teoría Pura del Derecho, trad. esp. de $2^{a}$. Ed. Alemana de R. J. Vernengo, Universidad Nacional Autónoma de México, México, 1982, p. 84.

112 Problemas capitales..., cit., pp. 105 y ss., 139 y ss., 163 y ss.

113 Teoría Pura del Derecho, $1^{\mathrm{a}}$ ed. cit., p. 47.

114 Teoría Pura del Derecho, $2^{\mathrm{a}}$ ed. p. 84. Véanse las pp. 84 y ss. Véase también Kelsen, H. Teoría general del Derecho y del Estado, trad. esp. de E. García Maynez, $5^{\mathrm{a}}$ reimpresión, de la $2^{\mathrm{a}}$ edición, Universidad Nacional Autónoma de México, México, 1995, pp. 52 y ss. 
to técnico que tiene como finalidad la ordenación y control de la vida social mediante la coacción. Explícitamente indica Kelsen al respecto: "La técnica específica del Derecho, que consiste - recordémoslo - en hacer seguir un acto de coacción visto como un mal a una conducta humana considerada como socialmente nociva, puede ser utilizada con miras a alcanzar no importa qué fin social, ya que el Derecho no es un fin sino un medio. Desde este punto de vista, el Derecho es una técnica de coacción social estrechamente ligada a un orden social que ella tiene por finalidad mantener" 115 .

En su obra póstuma, Teoría general de las normas, Kelsen reitera el carácter imperativo y coactivo de la norma jurídica ${ }^{116}$.

\section{C) Consideraciones críticas}

En relación con el pensamiento de Kelsen el Profesor A.E. Pérez Luño ha subrayado con agudeza la especial significación que la idea del Derecho como orden coactivo tiene en Kelsen. La relación entre Derecho y fuerza (coacción) adquiere en Kelsen, quizá, una significación extrema. Para Kelsen el Derecho no consiste en normas garantizadas por la coacción (Ihering), ni en normas reguladoras del ejercicio de la fuerza (coacción) por parte del Estado (Olivecrona, Ross) sino en normas revestidas de coacción, en normas cuyo contenido peculiar es la fuerza, la coacción ${ }^{117}$. Ello es lo que significa la caracterización del Derecho - frente a otros sistemas sociales- como orden coactivo (Zwangsordnung). En este sentido subraya Kelsen: "Los sistemas sociales designados como Derecho son órdenes coactivos de la conducta humana, en cuanto enla-

115 Kelsen, H. Teoría Pura del Derecho, $1^{\mathrm{a}}$ ed, cit., p. 74. Véase también Teoría Pura del Derecho, $2^{\mathrm{a}}$ ed., cit., pp. 46 y ss.

116 Kelsen, H. Teoría general de las Normas jurídicas, trad. esp. de H.C. Delory Jacobs, Ed. Trillas, México, 1994, pp. 43 y 44.

117 PÉRez Luño, A. E. Teoría del Derecho, (Una concepción de la experiencia jurídica), Ed. Tecnos, Madrid, 1997, p. 160, cfr. pp. 160 y 161. 
zan a la conducta contrapuesta un acto coactivo (sanción) dirigido contra el hombre que así actúa"118.

Si bien esa simbiosis entre Derecho y fuerza no está exenta de riesgos lo más peligroso, desde el punto de vista de la temática que en este estudio nos preocupa, consiste en el formalismo neutro, en el relativismo nihilista de Kelsen, según el cual el Derecho, en cuanto instrumento técnico de ordenación y control social, puede asumir como propio cualquier contenido. "Las normas jurídicas —dice Kelsen-pueden tener un contenido de cualquier clase. No hay ninguna especie de conducta humana que, por su misma naturaleza, no pueda ser convertida en un deber jurídico correlativo de un derecho subjetivo"119. Para Kelsen "la técnica específica del Derecho, que consiste (...) en hacer seguir un acto de coacción visto como un mal a una conducta considerada como socialmente nociva, puede ser utilizada con miras a alcanzar no importa que fin social, ya que el Derecho no es un fin sino un medio. Desde este punto de vista — añade-, el Derecho es una técnica de coacción social estrechamente ligada a un orden social que ella tiene por finalidad mantener" 120 .

El riesgo, insistimos, estriba en que desde el formalismo y el relativismo de Kelsen podría justificarse jurídicamente todo (detenciones, deportaciones, campos de concentración, etc.) ${ }^{121}$. Kelsen, sin pretenderlo, con sus remilgos formalistas y su obsesión por la neutralidad y el relativismo - así de fina es la dialéctica del Diablo-, nos coloca y nos abandona a las puertas mismas del Estado totalitario ${ }^{122}$.

118 Kelsen, H. Teoría Pura del Derecho, $2^{\mathrm{a}}$ ed, cit., p. 47. Véanse también las pp. 46 a 49.

119 Kelsen, H. Teoría general del Derecho y del Estado, cit., p. 133.

120 Teoría Pura del Derecho, $1^{\mathrm{a}}$ ed, cit., p. 74.

121 Teoría Pura del Derecho, $2^{\mathrm{a}}$ ed, cit., pp. 54 y 55.

122 Sobre el formalismo y relativismo de Kelsen véanse sus estudios: ¿Qué es justicia?, Absolutismo y relativismo en Filosofía y Política, El Derecho como técnica social específica, Dichos estudios aparecen reunidos, junto con otros, en el libro: Hans Kelsen, ¿̇Qué es Justicia?, Ed. y trad. esp. de A. Casalmiglia, Ed. Ariel, Barcelona, 1982, pp. 35 y ss., 113 y ss., 152 y ss.

Una especial crítica a la posición de Kelsen encontramos en RATZINGER, J. Verdad, Valores, Poder, (Piedras de toque de la sociedad pluralista), $2^{\mathrm{a}}$ ed. Ed. Rialp, Madrid, 1998, en especial las pp. 32 a 39, 44, 45, 50 51, 81 y ss., 87, 88, 92 a 97,104 y ss. 


\section{El realismo jurídico escandinavo}

\section{A) Noción y rasgos fundamentales}

\section{a) El positivismo lógico como supuesto epistemológico}

El realismo jurídico escandinavo constituye una corriente del pensamiento filosófico jurídico surgida a principios del siglo XX en Suecia y Dinamarca y cuyo centro espiritual es la Universidad de Uppsala. Por ello se le conoce también con la denominación de Escuela de Uppsala. Los representantes más significativos de dicha escuela fueron, A. Hägerström, A.W. Lundstedt, K. Olivecrona y A. Ross ${ }^{123}$.

El citado movimiento - que no tiene conexión directa con realismo americano- parte de los supuestos de un positivismo radical (positivismo lógico) que toma en consideración exclusivamente los hechos verificables por la experiencia y elimina en el estudio del Derecho todo elemento de carácter espiritual, valorativo, y todo resto o adherencia de signo metafísico ${ }^{124}$. En este sentido rechaza no sólo

123 Sobre la significación y rasgos del realismo jurídico nórdico en general véase: Castignone, S. La macchina del Diritto, (Il realismo giuridico in Svezia), Edizioni de Comunità, Milano, 1974; Hierro, L. L. El realismo jurídico escandinavo. Una teoría empirista del Derecho, Fernando Torres-Editor, Valencia, 1981; Pattaro, E. Y otros, Contributi al realismo giuridico, Dott, A. Guffré Editore, Milano, 1982. Contiene los siguientes estudios: E. PATTARo, Per una critica della dottrina pura, pp. XI y ss.; C. FARALli, Diritto e magia, Saggio su Axel Hägerström, pp. 5 a 169; R. HERnÁndez MARÍn, Diritto e Scienza, Saggio su Alf Ross, pp. 173 a 271. Fassó, G. La Filosofía del Diritto dell'Ottocento e del Novecento, (Nuova edizione aggiornata a cura di C. Faralli e G. Zanetti, Ed. Il Mulino, Bologna, 1996, pp. 247 y ss.)

124 Respecto de los supuestos epistemológicos del positivismo lógico hemos indicado en otro lugar: "Al positivismo lógico subyace un radical empirismo epistemológico que sostiene que todos los conocimientos acerca de la realidad proceden de la percepción sensible y de la introspección, posición esta que desemboca en una decidida actitud antimetafísica. El neopositivismo está animado de un espíritu receloso, atento fundamentalmente al rigor y a la claridad de la ciencia, actitud que manifiesta especialmente en su preocupación por el análisis y la depuración del lenguaje; tareas que eleva a objeto fundamental de su quehacer científico y filosófico. Sgnificativas de esta posición son las palabras de Wittgenstein: «Los límites de mi lenguaje significan los límites de mi mundo» (...). Como señalábamos al principio, el positivismo lógico parte del dato empírico y postula un empirismo radical que sitúa la única fuente de conocimiento en la 
el iusnaturalismo sino también el positivismo normativista, viendo en el mismo, incluido Kelsen, ideas y conceptos contaminados de iusnaturalismo.

\section{b) La concepción del Derecho como hecho}

Denominador común de esta corriente de pensamiento es entender el Derecho como un hecho del mundo empírico desprovisto de todo ingrediente o dimensión no ya metafísica o valorativa sino incluso psíquica. La concepción del Derecho como fenómeno psíquico-colectivo lleva a ver en el mismo un fenómeno de la imaginación que admite la existencia de deberes, obligaciones, derechos subjetivos, etc. Para el movimiento realista, dado su radicalismo antimetafísico, el Derecho no es más que un hecho, un fenómeno de la experiencia sensible que funciona como técnica de control social.

\section{c) La reducción de la Filosofía del Derecho a Teoría de la Ciencia jurídica}

Este modo de entender el Derecho condiciona también su concepción de la Ciencia jurídica y de la Filosofía del Derecho.

\footnotetext{
sensación, la cual no capta más que acontecimientos singulares y materiales, haciendo del principio de la verificabilidad — «comprobación» del sentido de una proposición; operación que incluye tanto el examen como el resultado y que sólo puede extenderse a las proposiciones empíricas; sólo hay verificación empíricael criterio en virtud del cual se determina la verdad o la falsedad de las proposiciones. Junto a las proposiciones fácticas, verificables empíricamente, están las proposiciones formales como las de la lógica y las matemáticas puras (tautologías). Para el neopositivismo solamente estas dos categorías de proposiciones son significativas. De ahí resulta —el objeto de la experiencia es exclusivamente la sensación - que toda la problemática metafísica es un pseudo-problema, un sin sentido que, en consecuencia, debe ser excluida del ámbito de la filosofía. Como sólo hay verificación empírica tenemos que los enunciados metafísicos y axiológicos constituyen - por inverificables- un «sin sentido», meros pseudoproblemas. Al no ser posible verificar la existencia de las cosas, pues sólo nos encontramos con sensaciones, toda la problemática de la «realidad», toda ontología, deviene un sin-sentido, y lo mismo acontece a la axiología y a la ética..." MONTOro Ballesteros, A. Sobre la revisión crítica del derecho subjetivo desde los supuestos del positivismo lógico. Prólogo de Rodrigo Fernández-Carvajal, Secretariado de Publicaciones, Universidad de Murcia, 1983, pp. 37, 42 y 43.
} 
Para esta corriente de pensamiento jurídico no existe más ciencia que la que tiene por objeto el conocimiento de la realidad empírica, de los hechos. Desde los supuestos de su empirismo radical y del positivismo lógico el realismo jurídico reduce la Filosofía del Derecho a Teoría de la Ciencia jurídica. Ésta tiene por objeto dotar al lenguaje jurídico de rigor y coherencia, depurando sus términos de toda adherencia de significación metafísica, emocional o ideológica y buscando la correspondencia de dichos términos con datos de la realidad empírica ${ }^{125}$.

Estas ideas iniciadas por A. Hägerström y A.W. Lundstedt, fueron desarrolladas especialmente por sus discípulos K. Olivecrona y A. Ross.

\section{B) La concepción positivista de K. Olivecrona y la reducción tecnicista del Derecho a fuerza}

a) Supuestos epistemológicos

El pensamiento de Karl Olivecrona descansa sobre los supuestos del positivismo lógico y de un empirismo radical.

Desde esta base Olivecrona se enfrenta con el lenguaje jurídico ordinario repleto de términos que denotan una indudable significación metafísica, ideológica, emocional y muestra su perplejidad. Escribe Olivecrona: "Se considera que los efectos jurídicos se producen porque el Derecho dice que ellos deben producirse. Hablamos como si el Derecho tuviese el poder de establecer una relación causal entre los hechos operativos y los efectos jurídicos. Los derechos (subjetivos) y los deberes son creados; los derechos son transferidos mediante declaraciones verbales. Las calidades o potestades jurídicas son conferidas a personas o cosas mediante ceremonias y declaraciones de las autoridades. La causalidad puede también afectar al pasado tal como ocurre cuando las consecuencias jurídicas de un acto

125 Boввio, N. Teoría della Scienza giuridica, G. Giappichelli, Ed. Torino, 1950, pp. 214 y ss.; Giongiani, V. Neopositivismo e Scienza del Diritto, Roma, 1956, pp. 186 a 191,259 a 270,271 y ss. 
son anuladas con efecto retroactivo. Cuando usamos este lenguaje, parece que moviéramos en una esfera de realidad diferente a la del mundo sensible. Sin embargo, esto no molesta en lo más mínimo a los juristas ni a los legos. Parece perfectamente natural que, en cuestiones jurídicas, se hable de esta manera... (pero) el teórico se encuentra en una situación diferente. Está inclinado a preguntar qué es todo esto. Supongamos que quiere utilizar sólo conceptos científicamente correctos, entendiendo por tales aquellos que corresponden a la realidad. En este caso tiene que preguntar qué es realmente un derecho (subjetivo) o un deber, en qué consisten en realidad las calidades jurídicas y como pueden ser creadas por hechos operativos tales como las declaraciones verbales (...) aquí comienzan las perplejidades" 126 .

Desde la perplejidad y turbación que dicho lenguaje causa a Olivecrona éste entiende que la tarea primaria de la Ciencia jurídica es la depuración del lenguaje jurídico y la redefinición de los conceptos jurídicos fundamentales.

\section{b) La revisión de los conceptos jurídicos fundamentales como tarea primordial de la Ciencia jurídica}

Esta tarea implica, nos dice Olivecrona, un cambio de los conceptos de cuño metafísico, ideológico o sobrenatural por otros dotados de base empírica ${ }^{127}$. Con esta intención estudia y replantea en su libro $E l$ Derecho como hecho los conceptos de Derecho, norma jurídica, carácter imperativo de la norma jurídica, derecho subjetivo, deber jurídico, objeto de Derecho, persona jurídica, etc.

$\mathrm{Al}$ objeto de nuestro estudio interesa, de modo especial, su revisión de la noción de Derecho y de derecho subjetivo,

126 Olivecrona, K. Legal language and reality, en "Essays in Jurisprudence in Honor of Roscoe Pound", Bobbs Merril Company, Inc. Indianápolis, New York, 1962, pp. 152 y 153. Hay trad. esp. de E. Garzón Valdés: Lenguaje jurídico y realidad, Buenos Aires, 1968.

127 Olivecrona, K. El Derecho como hecho, presentación y trad. esp. de la $1^{a}$. Ed. de G. Cortés Funes, Roque Depalma, Editor, Buenos Aires, 1959, pp. 135 y ss.; Lenguaje jurídico y realidad, cit., p. 18. 
a los que reduce a categorías puramente técnicas al servicio de la ordenación y del control social.

\section{c) Significación técnica de las nociones de Derecho y de derecho subjetivo}

\section{$1^{o}$. El Derecho como sistema de reglas que regula el uso de la fuerza}

Para Olivecrona, fiel a sus supuestos epistemológicos y metodológicos, el Derecho es un puro hecho o fenómeno social con forma imperativa, un simple fenómeno de fuerza organizada, cuyo ejercicio corresponde en régimen de monopolio al Estado ${ }^{128}$. El Derecho, en cuanto fenómeno de fuerza, posee dos dimensiones: El Derecho es fuerza psíquica (que ejerce sobre las personas un poder de sugestión) y fuerza física, poder de coacción que apoya - y en su caso genera - la sugestión. El Derecho, para Olivecrona, no consiste en normas garantizadas por la fuerza (Ihering) sino en una organización de fuerza, en normas relativas al uso de la fuerza ${ }^{129}$.

128 Olivecrona, K. El Derecho como hecho, cit., p. 133.

129 Escribe Olivecrona, desarrollando estas ideas: "Si descartamos la idea supersticiosa de que el Derecho emana de un Dios, es obvio — dice- que toda norma jurídica es una creación de los hombres. Las normas siempre han sido establecidas, por medio de la legislación o en otra forma, por gente de carne y hueso; en otras palabras, son el producto de causas naturales. Por otra parte, sus efectos también son naturales en cuanto ejercen presión sobre los miembros de la comunidad. Las normas del Derecho son motivos naturales - entre otros- de las acciones de los jueces en caso de litigio, así como de la conducta general de las personas en sus relaciones recíprocas... (Por esta razón, señala Olivecrona), nunca podemos eludir la conclusión de que el Derecho es un eslabón en la cadena de causa y efecto. Tiene, por lo tanto (el Derecho, añade Olivecrona) un lugar entre los hechos del mundo del tiempo y del espacio, pero entonces no puede pertenecer al mismo tiempo a otro mundo. El Derecho no puede, por una parte, ser un hecho (como lo es indudablemente) con causas naturales y efectos naturales, y, por la otra, algo extraño al vínculo de causa y efecto. Sostener lo contrario es pura superstición”. El Derecho como hecho, pp. 6 y 7, vid. p. 19.

Olivecrona avanza aún un paso más en el proceso de caracterización del fenómeno jurídico señalando el tipo específico de hechos a los que el Derecho pertenece: el Derecho consiste, para Olivecrona, lo mismo que para Lundstedt, en fuerza social organizada. Ibíd. p. 133. Olivecrona reconoce que la fuerza es tan peligrosa, tan destructiva para el hombre y para sus medios de subsistencia 
De ahí se deduce que en Olivecrona se produce una reducción del Derecho a mera técnica; a un instrumento técnico de ordenación y control social mediante la organización y regulación del uso de la fuerza.

\section{$2^{o}$. Significación de la idea de derecho subjetivo}

En relación con la idea de derecho subjetivo - categoría fundamental del pensamiento jurídico sometida a crítica y revisión por Olivecrona- se opera también en su pensamiento una reducción del mismo a un instrumento técnico para el ejercicio de la ordenación y el control social.

De acuerdo con los principios de que parte piensa Olivecrona que la idea de derecho subjetivo, entendida como un poder exclusivo atribuido a un sujeto para realizar determinadas actos o para exigir determinadas prestaciones, constituye un residuo mágico, metafísico, del pensamiento jurídico primitivo, que no se corresponde con ningún hecho de la realidad, y que, por tanto, no puede ser más que una pura "ficción": Un poder imaginario existente sólo en la mente de los hombres ${ }^{130}$.

Lo mismo afirma de la idea de soberanía en relación con el monopolio del uso de la fuerza social organizada

como el fuego cuando obra libremente, pero piensa que así como el fuego debe ser puesto al servicio del hombre si él ha de elevarse por encima del nivel de los animales, también la fuerza debe estar a su servicio si es que él ha de alcanzar un grado más alto de civilización. Ordenar la fuerza al servicio del hombre constituye la función primordial del Derecho; es más, en ello consiste el Derecho mismo. Lo que denominamos Derecho, dice Olivecrona, "es una fuerza organizada y regulada que se emplea contra criminales, deudores y otros según los moldes establecidos por los legisladores (...) El Derecho incluye fuerza o, más exactamente, existe en todo Estado una organización abrumadora de fuerzas que funciona según las normas llamadas Derecho. Por medio de esa organización (fuerza legal organizada) se mantienen en jaque otras formas de fuerza (la fuerza de carácter ilegal) (...) (El Derecho, puntualiza Olivecrona — el cuerpo de normas resumido en el concepto de Derecho-) consiste principalmente en normas concernientes a la fuerza, normas que contienen cánones de conducta para el ejercicio de la fuerza. (pues aunque existan normas que) contienen cánones o reglas son solamente otro aspecto de las normas sobre el uso de la fuerza, y estas normas son el factor decisivo (...) (porque a la larga) todo revierte en torno del uso regular de la fuerza”. Ibíd. pp. 97, 98, 103 y 104.

130 Olivecrona, K. El Derecho como hecho, cit., p. 67. Véanse las pp. 55 y ss., 99 у 100. 
dentro del marco del Estado en que consiste el Derecho. Afirma Olivecrona que el monopolio del ejercicio de la fuerza dentro de cierto territorio no consiste en el conocimiento y la atribución necesaria de ese poder de ejercicio a un sujeto, fundados en determinadas razones o títulos, sino en un puro "hecho" sin más justificación que la capacidad efectiva para ejercer ese monopolio ${ }^{131}$. Así Olivecrona somete a revisión también la idea de Estado ${ }^{132}$.

De otro lado, el Derecho en cuanto fuerza psíquica que genera un poder de sugestión posee una indudable eficacia psicológica, penetrando y modelando el pensamiento humano y su hábitos. Así tenemos que aunque el derecho subjetivo, en sí mismo considerado, no sea más que una ficción, un poder imaginario, que no se corresponde con nada del mundo exterior, de hecho se ha constituido en una "forma de pensar" muy arraigada en la mente de los hombres; en una "estructura de pensamiento", sin la cual resulta muy difícil, imposible, el discurso y el comercio jurídico entre los hombres.

Por esta razón Olivecrona ve útil y necesaria la utilización de la idea de derecho subjetivo de una forma realista. Se trata de hacer del derecho subjetivo una categoría instrumental, una categoría técnico-jurídica que sirve a la eficacia ordenadora del Derecho a través de una pluralidad de funciones pragmáticas.

131 Ibíd. pp. 134, 137 a 139 y 151.

132 Para Olivecrona los Estados no son otra cosa que organizaciones que han logrado un monopolio efectivo de la fuerza dentro de sus respectivas fronteras si bien es preciso observar que el efecto del Derecho, en cuanto regulador de la fuerza, es siempre relativo y aparece condicionado, por diferentes supuestos de carácter psicológico y material. (Ibíd. pp. 134, 137 a 139 y 151). En función de todo lo que antecede Olivecrona subraya así la significación de la Constitución en cuanto criterio fundamental de organización de la fuerza: "La actitud hacia la Constitución tiene un doble significado. Primero, determina positivamente al pueblo a aceptar las leyes debidamente promulgadas como obligatorias para todos y aceptarlas sin reflexión u oposición como cánones de su conducta. En segundo lugar, el poder de legislar es monopolizado por quienes han sido designados como legisladores según la Constitución. Las mentes de la gente están, por así decirlo, cerradas a toda otra dirección. Ningún otro puede obtener atención y obediencia en el campo reservado a los legisladores por la Constitución, y sugerir la posibilidad de competencia con ellos en ese campo carece de sentido en la mayoría de los casos”. Ibíd. p. 38. 
$3^{\text {o. }}$ Funciones de la noción de derecho subjetivo

El derecho subjetivo como categoría técnica del pensamiento jurídico se utiliza en la práctica jurídica para una serie de tareas o funciones entre las que destacan:

a) Una función lógico-conceptual, pues el derecho subjetivo constituye una categoría muy arraigada en la mente humana, indispensable para entender, hablar y manejar la materia jurídica y que, además, simplifica (reduce la complejidad), aclara e introduce seguridad en el tráfico jurídico.

b) Una función informativa, puesto que la idea de derecho subjetivo es una categoría muy arraigada en la mente humana, indispensable para entender y manejar los asuntos jurídicos y que introduce sencillez, simplicidad y seguridad en el tráfico jurídico.

c) Una función directiva de las conductas humanas. La idea de derecho subjetivo - como la idea de deberopera ordinariamente como norma de conducta, influyendo, condicionando y limitando le comportamiento humano.

d) Función de coadyuvante de la eficacia jurídica. La virtualidad de la idea de Derecho subjetivo para suscitar, potenciar o reprimir sentimientos jurídicos de poder y de deber hace que la misma incida y contribuya a incrementar el grado de eficacia de las normas, de los imperativos jurídicos. El sentimiento, la conciencia de poder que implica el derecho subjetivo - así como la conciencia de deber que suscita en la parte (o partes) opuesta (s) al titular del mismocontribuye a fortalecer la confianza en la eficacia de la norma que lo reconoce y protege ${ }^{133}$.

${ }^{133}$ En relación con la idea de derecho subjetivo como categoría técnico-jurídica en el pensamiento de K. Olivecrona véase mi libro Sobre la revisión crítica del derecho subjetivo desde los supuestos del positivismo lógico, cit., pp. 64 a 72. Citamos estas páginas porque en ellas aparece recogido y sistematizado el pensamiento de K. Olivecrona al respecto y nos evita repetir aquí la referencia prolija a la obra de Olivecrona en ellas contenidas. Sobre el pensamiento jurídico de K. Olivecrona véase: CASTiGnone, S. La macchina del Diritto, cit., pp. 141 a 205; 
C) El positivismo realista de A. Ross y la tecnificación de los conceptos centrales del pensamiento jurídico

a) Supuestos epistemológicos

El pensamiento jurídico de Alf Ross, Profesor de Copenhague y discípulo de a. Härgerström y H. Kelsen, posee también una significación radicalmente positivista, enraizada en el empirísmo inglés clásico y en el positivismo lógico. Desde estos supuestos metodológicos despliega Ross una vigorosa reflexión orientada a la crítica y revisión del pensamiento jurídico pasado y presente que desemboca en una concepción puramente técnica del Derecho.

b) Dimensiones crítica y revisionista del pensamiento de A. Ross

$1^{\circ}$. La crítica como punto de partida

Ante todo Ross somete a crítica las siguientes doctrinas jurídicas:

a) Ross critica el realismo jurídico americano; las tesis de que el Derecho consista básicamente en las decisiones de los jueces. Ross entiende que la significación jurídica de la situación del juez y de sus decisiones le vienen dadas por las normas jurídicas en virtud de las cuales es nombrado el juez y a las que él se siente obligado al adoptar sus resoluciones ${ }^{134}$.

b) Crítica del normativismo jurídico de Kelsen y de su pretensión de separar "ser" y "deber ser". Se trata, explica Ross, de una idea tomada de la filosofía prác-

\footnotetext{
Vergara Lacalle, O. El Derecho como fenómeno psicosocial. Un estudio sobre el pensamiento de K. Olivecrona, Ed. Comares, Granada, 2004; Montoro BALlesTERos, A. Notas sobre el realismo jurídico escandinavo: Derecho, efectividad e imperativismo jurídico en Karl Olivecrona, en "Anales de la Cátedra Francisco Suárez", Núm. 12, Fascículo 1º, Universidad de Granada, 1972, pp. 65 a 106.

134 Ross, A. Sobre el Derecho y la justicia, trad. esp. de G. R. Carrió, 5 5 a. Ed. Editorial Universitaria de Buenos Aires, Buenos Aires, 1994, pp. 42, 43, 66, 67, 71 y 72. Sobre A. Ross véase Hernández Marín, R. Diritto e Scienza. Saggio su Alf Ross, en el vol. "Contributi al Realismo Giuridico", cit.,
} 
tica de Kant, en la cual la norma tiene un fundamento metafísico, "a priori", que no aparece ni puede aparecer, por lógicas exigencias del positivismo jurídico, en la Teoría Pura del Derecho de Kelsen. A Kelsen, a pesar de su rigor lógico, a la hora de explicar el fundamento último de la "validez" ("deber ser") de la norma jurídica, no le cabe más remedio, contradiciendo sus premisas, que recurrir a un "dato fáctico": la eficacia o efectividad de orden jurídico ${ }^{135}$.

c) Crítica de las doctrinas jurídicas tradicionales que al admitir la dualidad "ser" y "deber ser", "realidad y validez", carecen de la coherencia lógica de las doctrinas de Kelsen y del realismo jurídico americano, desembocando en una serie de antinomias.

No obstante esto, Ross reconoce que las doctrinas clásicas, con su dualismo, sirven mejor a la comprensión, a la expresión de lo que es Derecho, el cual es, a la vez, algo válido y fáctico, ideal y real ${ }^{136}$.

$2^{\underline{o}}$. Revisión de los conceptos jurídicos fundamentales

a) Los conceptos de Derecho vigente y validez jurídica. Para Ross el Derecho vigente es una realidad que posee una doble dimensión empírica y técnica:

- El Derecho, ante todo, consiste en un fenómeno fáctico referido a la fuerza del Estado. Se trata del "conjunto de reglas para el establecimiento y funcionamiento del aparato de fuerza del Estado"137. El Derecho consiste pues en un conjunto de "normas o reglas relativas al ejercicio o uso de la fuerza", la cual aparece como "sanción, esto es, como una presión para provocar la conducta deseada"138.

135 Ross, A. Op. cit., pp. 66 a 69, 367 y 368; Ross, A. Hacia una Ciencia realista del Derecho, (Crítica del dualismo en el Derecho), trad. Esp. de J. Barboza, Ed. Abeledo-Perrot, Buenos Aires, 1961, pp. 46 y ss. Véase Kelsen, H. Teoría Pura del Derecho, $1^{\mathrm{a}}$ ed. cit., pp. 142 y ss.

136 Ross, A. Hacia una Ciencia realista del Derecho, cit., pp. 25 y 26, 56 y 57.

137 Ross, A. Sobre el Derecho y la Justicia, cit., p. 34.

${ }^{138}$ Ibíd. p. 58. Cfr. pp. 30, 55 y 68. 
- Al mismo tiempo, y como consecuencia del hábito y de la sugestión social que el funcionamiento de esas reglas produce en la conciencia de los ciudadanos, dichas normas aparecen revestidas del halo de la "validez", de la "legitimidad". Se trata de un fenómeno psicológico, de una ilusión - cuya causa y explicación última radica en la coacción de la fuerza- en virtud de la cual la mayoría de los ciudadanos no obedece la ley por temor al castigo sino porque "es la ley" y en cuanto tal "es obligatoria" 139. En este sentido el Derecho vigente constituye un esquema técnico de interpretación que, incorporando la idea de validez (que no es más que un hecho psicológico) nos permita comprender, como sucede con las reglas de un juego, el sentido de los actos que ocurren en el orden social regulado por el Derecho. El Derecho vigente, explica Ross, "significa el conjunto abstracto de ideas normativas que sirven como un esquema de interpretación para los fenómenos del Derecho en acción, lo que a su vez significa que estas normas son efectivamente obedecidas, y que lo son porque ellas son vividas (experienced and felt) como socialmente obligatorias" 140 .

Consecuente con sus supuestos epistemológicos piensa Ross que la idea de "validez" ha de ser reinterpretada "en términos de hechos sociales", realistamente, sólo como instrumento técnico para comprender la dinámica del orden jurídico, pero que la idea "validez" en sí ("deber ser"), como algo independiente de los hechos, no tiene más destino que desaparecer del ámbito del pensamiento científico, donde sólo cabe el fenómeno sociológico de la eficacia ${ }^{141}$.

Junto a la concepción técnica del Derecho de Ross y a su revisión de la idea de validez jurídica, entendi-

139 Ross, A. Hacia una Ciencia realista del Derecho, cit., pp. 93.

140 Ross, A. Sobre el Derecho y la Justicia, cit., p. 18. Cfr. p. 66; Hacia una Ciencia realista del Derecho, cit., pp. 89.

${ }^{141}$ Ross, A. Sobre el Derecho y la Justicia, cit., p. 67 y ss. 
da como fenómeno psicológico social, resulta interesante desde el punto de vista de nuestro estudio su revisión y concepción del derecho subjetivo, al que reduce a una categoría técnica útil para la legislación y la Ciencia jurídica.

b) El derecho subjetivo como categoría técnica del pensamiento jurídico. Aquí A. Ross no hace más que desarrollar las aportaciones de sus maestros Kelsen y Hägerström. Del primero recoge, fundamentalmente, la preocupación por desenvolver un pensamiento rigurosamente lógico y coherente; del segundo, la necesidad de desterrar la metafísica del pensamiento científico.

Ross pretende llevar a cabo, hasta sus últimas consecuencias, de acuerdo con estos supuestos, un análisis realista del Derecho positivo y de su categorías conceptuales fundamentales, realizando un replanteamiento y revisión de la doctrina científica (en eso consiste para él la tarea fundamental de la Filosofía del Derecho) desde supuestos radicalmente empiriológicos y antimetafísicos. En este sentido pretende hacer del lenguaje jurídico y del aparato lógicoconceptual de la Ciencia del Derecho un instrumento riguroso, coherente y útil para permitir al jurista, tanto teórico como práctico, comprender mejor lo que hace y por qué lo hace ${ }^{142}$.

Desde estos supuestos Ross lleva a cabo una tarea de crítica y revisión de la idea de derecho subjetivo en la que cabe destacar dos momentos fundamentales:

1. La crítica y rechazo de la idea de derecho subjetivo como categoría metafísica, en la línea de Hägerström y Lundstedt. Se trata de la negación del derecho subjetivo entendido como un poder invisible respecto de una persona o cosa, poder que no se corresponde con ningún hecho concreto y que tiene un origen mágico y una función ideológica. La idea de derecho

${ }^{142}$ Ibíd. pp. 25 y ss. 
subjetivo tal como aparece en la Ciencia jurídica tradicional constituye una categoría metafísica (un sin sentido) que no designa ningún fenómeno real ${ }^{143}$.

En cuanto tal la idea de derecho subjetivo no tendría cabida en el lenguaje riguroso y coherente de la Ciencia jurídica realista que Ross propugna ${ }^{144}$.

2. La conversión del derecho subjetivo en una categoría técnica de representación útil y necesaria para la legislación y la Ciencia jurídica.

Ross, al contrario que Hägerström y Lundstedt, no defiende el abandono y destierro de la noción de derecho subjetivo del ámbito del lenguaje jurídico sino el uso realista de dicha idea ante la imposibilidad práctica de prescindir de ella en el lenguaje jurídico. Y ello porque ideas como derecho subjetivo, facultad, deber... etc. son términos firmemente arraigados y asimilados por el pensamiento y por la ciencia jurídicas y sin los cuales difícilmente podrían éstos desenvolverse con fluidez y eficacia. Ross no rechaza pues la idea de derecho subjetivo sino que propone, a través del lenguaje, su racionalización, depurándola de ambigüedades y dotándola de rigor y seguridad científicas ${ }^{145}$. Como Olivecrona, piensa Ross que la expresión derecho subjetivo constituye una mera técnica o cauce de expresión apto para formular directivas e influir en el comportamiento humano. El uso realista del derecho subjetivo hace del mismo una técnica o "instrumento de representación" adecuados para llevar a cabo las funciones de la legislación y de la Ciencia jurídica ${ }^{146}$.

143 Ibíd. pp. 167 y ss.

144 Sobre este punto y por razones de economía de espacio y tiempo véase mi libro, Sobre la revisión crítica del derecho subjetivo desde los supuestos de positivismo lógico, cit., pp. 75 y ss., 79 y ss. En dicho libro aparecen las pertinentes referencias a la obra de A. Ross.

${ }_{145}$ Como en otro plano hizo con las categorías de "ius in rem" y "ius in personam", Ross, A. Sobre el Derecho y la Justicia, cit., pp. 184 y ss. Cfr. MonToro Ballesteros, A. Sobre la revisión crítica del derecho subjetivo desde los supuestos de positivismo lógico, cit., pp. 86 y ss.

146 Montoro Ballesteros, A. Sobre la revisión crítica del derecho subjetivo desde los supuestos de positivismo lógico, cit., pp. 83 a 86 . Sobre Ross véase tam- 
4. El funcionalismo en el Derecho:

Notas sobre N. Luhmann y G. Jakobs

\section{A) Introducción}

El funcionalismo es una corriente metodológica que se desarrolla básicamente en la segunda mitad del siglo XX (R. K. Merton, T. Parsons...) y que se extiende por los ámbitos de la antropología, la sociología, la psicología, la política..., alcanzando incluso al Derecho.

El funcionalismo encuentra un precedente remoto en el organicismo del siglo XIX y su raíz, más próxima e inmediata, en el pensamiento sociológico de E. Durkheim (Las reglas del método sociológico, 1895).

El método funcionalista se propone como objetivo la comprensión y explicación de las estructuras sociales, no a partir de su origen histórico y de sus peculiaridades espaciales (geografía) y temporales, sino tomando como punto de partida la observación, análisis y estudio de las funciones que realizan las estructuras sociales dentro de la sociedad o en parte de ella ${ }^{147}$.

Desde estos supuestos nuestra pretensión es ofrecer una sinopsis sobre la significación del funcionalismo en el pensamiento jurídico a partir de las teorías de N. Luhmann y G. Jakobs.

\section{B) El pensamiento sistémico de N. Luhmann \\ a) El proyecto científico de Luhmann}

La pretensión de Luhmann en su Systemtheorie es la continuación y actualización crítica del funcionalismo

\footnotetext{
bién mi estudio, sobre la superación del formalismo jurídico en el realismo nórdico: La doctrina de la interpretación de Alf Ross, en "Anuario de Filosofía del Derecho", Tomo XVIII, Madrid, 1975, pp. 153 a 202.

147 Meehan, E. J. Pensamiento político contemporáneo, Estudio crítico, trad. esp. de F. Rubio Llorente, Ed. Revista de Occidente, Madrid, 1973, pp. 105 y ss. Véase también TimashefF, N. S. Teoría sociológica (Su naturaleza y desarrollo), trad. esp. de F. M. Torner, $5^{\mathrm{a}}$. Reimpresión de la $1^{\mathrm{a}}$ ed. Fondo de Cultura Económica, México, México, 1971, pp. 276 y ss.
} 
estructural de T. Parsons. Construir una Teoría de la sociedad, completa y exhaustiva, de carácter interdisciplinar - y dentro de ella una Teoría del Derecho- sirviéndose como instrumento metodológico de la teoría de los sistemas.

El intento de Luhmann cristaliza en una visión deshumanizada y tecnificada de la sociedad cuyos rasgos fundamentales son:

$1^{\circ}$. La complejidad social.

Se trata de la complejidad de la sociedad actual en cuanto sistema, en la cual el hombre aparece situado ante un amplísimo horizonte de posibilidades de actuación con la consiguiente perplejidad y dificultad para elegir, lo cual supone contingencia y riesgo.

$2^{\circ}$. La limitación de la razón humana.

La natural limitación de la razón humana (imbecillitas, en su sentido clásico) para reducir por sí misma la complejidad del mundo.

$3^{\text {o. }}$ El sistema como instrumento cognitivo.

Nos referimos al recurso a la idea de sistema como instrumento (aparato técnico) para posibilitar la comprensión del mundo y la reducción de su dramática complejidad, haciendo posible la orientación y actuación humanas, puesto que el sistema - los sistemas normativos- permiten construir expectativas estables, sólidas, sobre el comportamiento de uno mismo y del de los demás ${ }^{148}$.

148 Cfr. Luhmann, N. Sociedad y Sistema: La ambición de la Teoría, trad. esp. de S. López Petit y D. Schmitz, Introducción de I. Izuzquiza, Ed. Paidós, Barcelona, 1997, pp. 41 y ss., 67 y ss., 75 y ss.

El pensamiento de N. Luhmann me parece asistémático, complejo y oscuro. Por ello, en la construcción de esta sinopsis, me voy a servir básicamente de las claras y rigurosas exposiciones de J. I. Martínez García, Justicia e igualdad en Luhmann, en "Anuario de Filosofía del Derecho", Nueva Época, Tomo IV, Madrid, 1987, pp. 41 y ss., e I. Izuzquiza, Introducción: La urgencia de una nueva lógica, introducción a Sociedad y Sistema de N. Luhmann, ya citada. En relación con lo escrito hasta este momento véase: MARTínez GaRCíA, J. I. Op. cit., pp. 44, 55, 56, 62 y 85. Véase también OLLERO, A. Derecho y Sociedad (Dos reflexiones entorno a la Filosofía jurídica alemana actual), Editora Nacional, Madrid, 1973, pp. 120 y ss., 143 y ss. 
b) Teoría de la sociedad

Luhmann -haciéndose eco de los nuevos avances de la ciencia (física, biología, cibernética, neurofisiología, etc.)— entiende la sociedad no como una suma de individuos sino como un sistema (totalidad de estructura sistemática), integrada, a su vez, por una pluralidad de subsistemas que tienen su propia estructura y autonomía.

Los sistemas están formados de elecciones sucesivas y referidas entre sí que tienen la función de facilitar la comprensión de la realidad y reducir la complejidad, encontrando soluciones en un mundo cambiante. El núcleo central de los sistemas está constituido por la "comunicación", que supone no sólo el intercambio lingüístico sino también el de la acción. Los sistemas son pues medios de comunicación (en ello radica su racionalidad) que aseguran en su ámbito la transmisión de la complejidad reducida realizada por dichos sistemas, según un esquema binario (verdad-falsedad, lícito-ilícito, etc.) ${ }^{149}$.

Los sistemas constituyen estructuras de todo tipo - familias, empresas, sociedades, iglesias, estados- integradas por acciones concretas que para mantenerse y subsistir en su medio ambiente han de resolver multitud de problemas ${ }^{150}$.

Para Luhmann, inspirándose en las teorías biológicas (H. Maturana), los sistemas se caracterizan por las notas de autoreferencia y autopoiesis.

- La autoreferencia alude a la distinción entre el sistema y su entorno, viendo en el sistema un todo cerrado en donde todas sus operaciones y elementos aparecen referidos a sí mismos.

- La autopoiesis (autoproducción) significa que los sistemas sociales, igual que los sistemas psíquicos y orgá-

149 Luhmann, N. Soziale Systeme (Grundrig einer allgemeinen Theorie), Frankfurt am Mainz, 1984; MARTínez GarCía, J.I. Op. cit., pp. 51 y 52 y ss., nota 21; IZUZQUIZA, I. Op. cit., pp. 25 a 28.

150 Martínez García, J. I. Op. cit., pp. 47 (notas 10 y 11), 49 y 51 (notas 14 y 15). 
nicos, tienen la capacidad de producir, ellos mismos, los elementos que los integran, construyendo su propio espacio de operación y reducción de la complejidad ${ }^{151}$.

De acuerdo con lo anteriormente indicado la sociedad, compuesta por sistemas de comunicaciones, puede diferenciarse progresivamente, reduciendo su complejidad, en diferentes subsistemas sociales tales como la economía, la política, la religión, la educación... y el Derecho ${ }^{152}$.

\section{c) Teoría del Derecho}

En la teoría sistémica del Derecho Luhmann distingue tres nociones o categorías fundamentales: el sistema jurídico, los derechos fundamentales y la justicia.

\section{$1^{\text {o. }}$ El sistema jurídico}

Luhmann concibe el Derecho como un subsistema específico del complejo sistema social, definido básicamente por la nota de positividad, y que se diferencia funcionalmente de los otros subsistemas sociales (económico, moral, político, etc.) por su específico entramado de comunicación consistente en su propio sistema binario - distinción entre lo jurídico (Recht) y lo antijurídico (Unrecht) — capaz de establecer y fijar determinadas "expectativas normativas de conducta".

Estas expectativas de conducta deben ser generalizadas en tres dimensiones:

1. Dimensión temporal: Conservación de las expectativas con independencia de que se realicen o no.

2. Dimensión social: Institucionalización de las expectativas mediante el consenso.

3. Dimensión material: Identificación de los contenidos o materias sobre las que versan las expectativas ${ }^{153}$.

${ }^{151}$ Luhmann, N. Sociedad y Sistema, cit., pp. 87 y ss., 121 y ss.; IzUZquizA, I. Op. cit., pp. 17 a 25; Martínez García, J. I. Op. cit., p. 54, notas 31 y 32.

152 IZUZQUIZA, I. $O p$. cit., pp. 25 y ss.

${ }^{153}$ MarTínez GarCía, J.I. Op. cit., pp. 57, 58 y 61 (notas 42, 45 y 57). 
La abstracción y deshumanización del pensamiento sistémico de la Luhmann (en relación con él se ha hablado de una "sociedad sin hombres"154) culmina en la revisión y tecnificación de las ideas de derechos fundamentales y de justicia que, en cuanto categorías centrales del pensamiento jurídico, aparecen configuradas como imágenes surrealistas.

\section{$2^{\circ}$. Los derechos fundamentales}

Para Luhmann los derechos fundamentales no son ya derechos naturales o humanos del individuo, basados en la dignidad humana y otros valores de la persona que el Derecho deba reconocer y proteger (ello es pura metafísica). Para él los derechos fundamentales consisten en piezas o instituciones técnicas del sistema social (estructuras intrasistemáticas) constituidas por un conjunto de expectativas de comportamiento sostenidas por el consenso, y que operan en el sistemas social como filtros y límites técnico-jurídicos frente a la tendencia expansiva del Estado o sistema político, garantizando la diferenciación y la operatividad del sistema jurídico ${ }^{155}$.

\section{$3^{\circ}$. La idea de justicia}

Respecto de la Justicia cabe decir que dicha categoría pierde en el pensamiento de Luhmann, como cabía esperar, toda significación ética para quedar reducida a una vaga, fría y técnica cualidad del sistema jurídico.

La justicia consiste para Luhmann en la "adecuada complejidad del sistema jurídico"156 entendido, no como conjunto de normas sino como sistema de acción y de experiencia

${ }_{154}$ IzUZquiza, I. La sociedad sin hombres. Niklas Luhmann o la teoría como escándalo, introducción a N. LuHMANN, Sociedad y Sistema, cit., p. 38.

155 Luhmann, H. Grundrechte als Institutions: Ein Beitrag zur politischen Soziologie, 2a Auf. Duncker und Humblot, Berlín, 1974, pp. 12, 13, 23 a 25, 71, 72182 a 185, 187 y 198. Cfr. Martínez GarCía, J. I. Op. cit., pp. 50, 51 (notas 17 a 19), 67 y 68 (notas 75 a 78 ).

156 Luhmann, N. Gerechigkeit in den Rechtssystemen der modernen Gesellshaft, en "Rechtstheorie", 4 Band, Heft 2, 1973, p. 142. Cfr. MarTínez García, J.I. Op. cit., p. 72 (nota 88). 
orientado por el Derecho. La justicia constituye así un criterio regulativo, interno al sistema, y referido a la operatividad del mismo, que no debe colapsarse ni bloquearse, permitiendo la adopción de decisiones fluidas y coherentes ${ }^{157}$.

\section{C) La concepción funcional del Derecho Penal de G. Jakobs}

a) La conservación de la sociedad como función primaria del Derecho

La idea central de funcionalismo de Günther Jakobs es la necesidad de que el sistema social (sociedad) funcione adecuadamente y tenga los medios precisos para su autoconservación y autodefensa ${ }^{158}$.

Desde esta perspectiva el Derecho (y de modo especial el Derecho penal que es el que interesa a Jakobs) forma parte del sistema social y tiene como función primaria el mantenimiento y defensa del sistema social vigente, dotándolo de cohesión y resolviendo cualquier problema que pueda afectar al funcionamiento del mismo ${ }^{159}$.

Esto es válido para cualquier tipo de sociedad y no implica necesariamente desconocimiento o sacrificio de la libertad que sólo puede desarrollarse en el seno de una sociedad en funcionamiento y que, en cualquier caso, depende siempre (nos referimos al problema de la libertad) de la actitud del sujeto ${ }^{160}$.

b) El Derecho como factor de identificación y garantía de la sociedad

La configuración e identificación de la sociedad (en cuanto sistema de comunicación) se lleva a cabo mediante

157 Luhmann, N. Gerechigkeit..., cit., pp. 145, 154 y 156; Martínez García, J. I. Op. cit., pp. 73, 74 y 79.

158 JaKoBS, G. Sociedad, norma y persona en la Teoría de un Derecho penal funcional, trad. esp. de M. Cancio Meliá, y B. Feijóo Sánchez, 1ª ed. Ed. Civitas, Madrid, 1996, pp. 36 у 37.

159 Ibíd. pp. 20 a 22,24 y 43.

160 Ibíd. pp. 29 a 34, 36 у 37. 
las normas jurídicas. Éstas son las que, dentro de la dinámica social, permiten saber el significado de los comportamientos de la persona y lo que razonablemente puede esperarse de ella ${ }^{161}$.

Según G. Jakobs dichas normas, en cada momento, no tienen que ser necesariamente como son sino que podrían ser de cualquier otro modo. Esta apertura de Jakobs al relativismo, al nihilismo, incluso, hace que, dado el carácter contingente del contenido de las normas, su confirmación, su validez y eficacia se encomienda, sin más, a una medida de fuerza, a una sanción ${ }^{162}$. Ello explica, según Jakobs, que sea fundamentalmente el Derecho penal el que mejor contribuye a identificar y definir el tipo de sociedad de que se trate en cada tiempo y lugar. En este sentido entiende G. Jakobs: "Que la pena máxima se imponga por brujería, por contar chistes sobre el Führer o por asesinato, caracteriza a ambos, al Derecho penal y a la sociedad"163.

Desde los supuestos de ese funcionalismo, — sin más fundamentación filosófica que el relativismo y el nihilismo- se entiende que, según Jakobs, el problema social planteado por el delito tenga como única solución la confirmación de las normas del sistema por parte del Derecho penal. La finalidad de éste, entiende Jakobs, no es tanto la protección de "bienes jurídicos" como la defensa y garantía de las normas que determinan la identidad del sistema ${ }^{164}$. Jakobs afirma explícitamente que el "funcionalismo jurídico-penal se concibe como aquella teoría según la cual el Derecho penal está orientado a garantizar la identidad normativa, la constitución y la sociedad" 165 .

Dicha sociedad, siguiendo a N. Luhmann, no es entendida por G. Jakobs desde el punto de vista individualista que ve la sociedad como la obra de sujetos individuales que la crean y la legitiman mediante el contrato (Hobbes, Kant) y dictan sus propias leyes, sino desde la perspectiva de la co-

\footnotetext{
161 Ibíd. pp. 52 y 53.

162 Ibíd. pp. 26 a 28.

163 Ibíd. p. 22. Veánse las pp. 20 a 24.

164 Ibíd. pp. 17, 18, 25 y ss., y 44 a 49.

165 Ibíd. p. 15.
} 
munidad, de la sociedad misma (sistema social de comunicación) que genera y garantiza sus propias reglas ${ }^{166}$.

\section{c) Consecuencias}

Desde la base de esa concepción de la sociedad y del Derecho es lógico que Jakobs entienda:

1. Que siendo el delito la negación de la norma la pena ha de tener como función exclusiva la confirmación de la norma (en su dimensión externa, formal) sin plantearse el tema de la dimensión interna, material, de la misma; esto es, el asunto del "bien jurídico" protegido por dicha norma, según el planteamiento tradicional del Derecho penal ${ }^{167}$.

2. La pena aparece pues desprovista de toda función o finalidad psicológico-social o individual (prevención, reducción...). Su única tarea es la confirmación de la norma y, a través de ello, la afirmación y aseguramiento de la identidad de la sociedad en cuanto sistema social ${ }^{168}$.

3. La concepción funcionalista de Jakobs se prolonga en la revisión y replanteamiento de otras categorías centrales del Derecho penal (idea de persona como sujeto del Derecho penal, imputación objetiva, culpabilidad, dolo... $)^{169}$, las cuales a la luz de su pensamiento, cobran un aire surrealista, espectral que nos impulsa, como primera reacción, a llevarnos las manos a la cabeza.

\section{d) Consideraciones críticas}

Al funcionalismo de Jakobs subyace, como único apoyo, según se ha indicado ya, un relativismo, un nihilismo axiológico, ético, en virtud del cual cualquier sistema so-

\footnotetext{
166 Ibíd. pp. 15 y 16.

167 Ibíd. pp.17, 18, 63 y 64.

168 Ibíd. pp. 18 y 19.

169 Ibíd. pp. 50 y ss.
} 
cial existente, por el simple hecho de su existencia, es válido y debe ser protegido mediante el Derecho. Sociedad y Derecho forman un binomio puramente "neutro", una estructura técnica como la constituida por cualquier mecanismo cuya existencia y funcionamiento es independiente e indiferente a toda exigencia o valoración ética ${ }^{170}$.

Lo anteriormente indicado explica que para Jakobs, la concepción funcional de la sociedad y del Derecho, en cuanto categorías éticamente "neutras", sean compatibles tanto con una sociedad esclavista (sociedad instrumental) - en la que el esclavo es un objeto, una cosa, pero no una persona; sociedad que posee su propia lógica y dinámica y que puede ser comprendida y explicada funcionalmente- ${ }^{171}$, como con una sociedad de hombres libres (sociedad no instrumental) en la que, según la formulación clásica de Hegel, "el mandato del Derecho (sería) por tanto: sé una persona y respeta a los demás como personas" 172 .

Como se ha podido ver a lo largo de las consideraciones precedentes la concepción funcionalista de la sociedad y del Derecho de Jakobs tienen como resultado la conversión del Derecho en un mero instrumento técnico al servicio del "funcionalismo social". Los importante aquí es que la sociedad (con independencia del tipo de sociedad de que se trate) - ya se autocrática o democráticafuncione y tenga medios de autoconservación y defensa. El Derecho aparece así despojado de toda dimensión o referencia ética (sólo le interesa el valor técnico de la utilidad entendido como funcionalidad) resultando ciego e impotente en relación con el problema de la defensa y cambio de otros valores, en especial de los éticos. Para Jakobs, en sintonía con Kelsen, los problemas axiológicos, éticos, son cuestiones que no competen al Derecho sino a la Política ${ }^{173}$.

170 Ibíd. pp. 20 a 22.

171 Ibíd. pp. 37 y 38.

172 Hegel, H. Rechtsphilosophie, parágrafo 36; Cfr. JAKOBS, G. Op. cit., pp. 38 y 39 .

${ }^{173}$ Ibíd. pp. 40 y 41. 


\section{El análisis económico del Derecho}

\section{A) Supuestos y Objetivos}

Con el nombre de Análisis Económico del Derecho (Economic Analysis of Law), se conoce una corriente epistemiológica y metodológica que tuvo su origen en la Universidad de Chicago, entre finales de los años cincuenta y principios de los sesenta. Su desarrollo y consolidación tuvo lugar durante los años sesenta y setenta, extendiéndose a otras importantes Universidades americanas (Stanford, Columbia, George Mason, Miami, Emoy...). Su recepción en Europa se produjo a finales los años setenta y comienzos de los ochenta, momento en el que el Análisis Económico del Derecho adquiere su plena madurez, tanto como método como disciplina autónoma ${ }^{174}$.

Las raíces de este movimiento las encontramos en los trabajos de F. Knight, Th. Schult, H. Simons y M. Friedman. A este núcleo inicial, en el que destaca la figura de Friedman, hay que añadir los nombres de G.S. Becker, J.M. Buchanan y, sobre todo, los de R. H. Coase, G. Calabresi y R. Posner. Coase, Calabresi y Posner son las figuras más representativas de esta corriente doctrinal.

Debe advertirse que el Análisis Económico del Derecho no constituye una escuela unitaria sino un movimiento, dentro del cual - compartiendo determinados supuestos epistemológicos y metodológicos- se desenvuelven diferentes tendencias o corrientes entre las que hay que destacar:

- La línea conservadora o Escuela de Chicago, liderada por R. Posner.

- La tendencia liberal-reformista encabezada por G. Calabresi.

- La corriente neoinstitucionalista, que tiende a configurarse como una "tercera vía", y en donde destaca,

174 Vid. Mercado Pacheco, P. El análisis Económico del Derecho, (Una reconstrucción teórica), Ed. Centro de Estudios Constitucionales) Madrid, 1994. pp. 25, 27 y ss.; 32,74 y ss.; $167 y$ ss. 
entre otros, W.S. Samuels ${ }^{175}$. Para esta tendencia los grupos sociales y no los individuos, son los verdaderos protagonistas de la vida económica.

El Análisis Económico del Derecho, partiendo de los principios del utilitarismo y del pragmatismo filosófico americano (Peirce, Ames, Dewey), tiene como supuestos doctrinales y metodológicos, más inmediatos, junto a los principios del neoliberalismo económico (libertad económica individual, eficiencia económica y equidad en la distribución de recursos), la idea de que los objetos de las ciencias sociales (Historia, Política, Derecho...) poseen una naturaleza y estructura similar al objeto propio de la Ciencia económica - la conducta humana (G. Becker, R. Posner)-, por lo que son susceptibles de ser estudiados desde el punto de vista de la Teoría económica, entendida como método (en este sentido se ha hablado del "imperialismo" de la Ciencia económica. $)^{176}$.

Desde estos supuestos, la pretensión del Análisis Económico del Derecho es elevar la jurisprudencia (el estudio del Derecho) a la condición de verdadera ciencia, de ciencia racional y positiva, mediante el análisis y la investigación del Derecho de acuerdo con los principios, categorías y métodos específicos del pensamiento económico. En este sentido, según R. Posner, la aplicación de la teoría microeconómica neoclásica (y más concretamente, de la teoría microeconómica del bienestar), al análisis de las principales instituciones del sistema jurídico en su conjunto, permitirá predecir y explicar el comportamiento de los individuos en relación con las normas jurídicas ${ }^{177}$. Esta corriente metodológica trata, en definitiva, de liberar el co-

175 Ibíd. pp. 33, 58 y ss., 60 y ss., 62 y ss.

176 PAZ-AREs, C. La Economía Política como jurisprudencia racional (Aproximación a la Teoría Económica del Derecho), en "Anuario de Derecho Civil", Tomo 34, Fascículo III, julio-septiembre, 1981, pp. 605 a 607; PASTOR PrIETo, S. Sistema jurídico y economía, (Una introducción al Análisis Económico del Derecho), Ed. Tecnos, Madrid, 1989, p. 33; Mercado Pacheco, P. Op. cit., pp. 33 y ss., 75 y ss., 77 y ss., 88 y ss., 91 y ss., 208 y ss., 264 y ss.

177 Cfr. Mercado Pacheco, P. Op. cit., pp. 22 y ss., 33 a 36, 39 a 45, 68 y s.., 72 y ss., 74 y ss., 174 y ss., 177 y ss., 198,204 a 210,266 y ss. 
nocimiento jurídico —que, según expresión de R. Posner, se encuentra todavía en un estado precientífico- del arcaico aparato metodológico y conceptual de la Ciencia jurídica tradicional. [-Incapaz de adaptar las categorías y los métodos del pensamiento jurídico a la nueva realidad social americana, caracterizada por la crisis del Estado de Bienestar (B.A. Ackerman)—] $]^{178}$, haciendo de la misma una auténtica ciencia, caracterizada por su rigor, su objetividad y su racionalidad. Esa nueva y rigurosa Ciencia jurídica, la Teoría Económica General del Derecho, cuyo objetivo básico — de acuerdo con el principio de eficiencia económica ${ }^{179}$, (que es un criterio de valor seguro, calculable y objetivo ${ }^{180}$ - consistiría en el estudio, a partir del análisis metódico y global de la estructura y del funcionamiento del Derecho, del modo de minimizar el empleo de los recursos (evitando el despilfarro) y, al mismo tiempo, aumentar la eficiencia de los mismos ${ }^{181}$. Se piensa así, indica Mercado Pacheco, que la "ciencia económica pone a disposición del jurista su arsenal teórico para dotarle de los instrumentos aptos para enfrentarse a los problemas prácticos del Derecho. Prácticos y técnicos, porque el jurista descubre a través del Análisis Económico del Derecho que detrás de todo problema jurídico hay un problema de elección, de decisión de recursos escasos, una decisión que

178 Ibíd. pp. 181 y ss., 193 y ss., 200 y ss., 211 y ss., 260 y ss., 273, 280 y ss.

179 Dicho principio tiene como meta lograr el cumplimiento de un objetivo determinado, minimizando el empleo de recursos. Se trata pues de utilizar los recursos limitados de que dispone la sociedad, de modo que, evitando el despilfarro, se alcance el mayor grado posible de satisfacción de necesidades. Posner ha entendido el principio de eficiencia económica como maximización de la riqueza, lo cual significa para Posner, "explotar los recurso Económicos de tal manera que su valor - la satisfacción humana medida por la voluntad de pago del consumidor por los bienes y servicios- sea maximizado". Economic Análysis of Law, Little Brown and Company. Boston and Toronto, 1973, p. 10. Vid. MERCADO PACHECO, P. pp. 55 y ss.

180 Cfr. Mercado Pacheco, P. Op. cit., pags. 37, 260 y ss., 273.

181 PAZ-AREs, C. Op. cit., pp. 627, 628 y 696; SCHÄFER, H.B. y OTT, C. $M a-$ nual de Análisis Económico del Derecho, trad. esp. de M. von Carstern-Lichterfelde, Ed. Tecnos, Madrid, 1982, p. 21; ToRRes LóPEz, J. Análisis Económico del Derecho (Panorama doctrinal), Ed. Tecnos, Madrid, 1987, p. 90; MERCAdo PACHECO, P. Op. cit., pp. 208 y ss., 260 y ss., 280 y ss. 
sólo puede ser tomada tras el análisis de los costes y beneficios de la situación" 182 .

De este modo se piensa que la solución de todo problema jurídico es racionalizada y objetivada al ser reducida a una simple operación de cálculo de costes y beneficios ${ }^{183}$. En este sentido, aclara Mercado Pacheco, que "la uniformidad de las decisiones del sistema jurídico no reside en sus características formales (...) sino en la traducibilidad de las soluciones jurídicas a soluciones económicas. Esa traducibilidad significa — añade Mercado Pacheco- que el análisis económico permite descubrir una realidad - la lógica económica del mercado y la eficiencia- que representa la razón de ser del Derecho, su lógica subyacente"184.

\section{B) Ámbitos de aplicación y tareas}

De acuerdo con los supuestos epistemiológicos y metodológicos de G. Becker ${ }^{185}$ y de R. Posner ${ }^{186}$, el análisis económico es el método racional adecuado para comprender y explicar, no sólo el comportamiento económico, sino, al mismo tiempo, cualquier tipo de conducta humana; cualquier sector de la vida del hombre ${ }^{187}$. Entre esos sectores o ámbitos de la vida humana destacan el jurídico y el político.

En relación con el análisis económico de la vida política (teoría constitucional, burocracia, comportamiento de los partidos políticos, sistemas electorales, etc.) destacan las investigaciones de J. M. Buchanan ${ }^{188}$.

182 Op. cit., p. 274.

183 Ibíd. pp. 269, 270 y ss., 273 y ss., 276 y ss.

184 Ibíd. p. 281.

185 The Economic approach to human behavior, University of Chicago Press, 1976.

186 The Economic of Justice, Harvard University Press, Cambridge Mass and London, 1983.

187 Cfr. Mercado Pacheco, P. Op. cit., pp. 77 y ss., 80 a 91,91 y ss.

188 The Limits of liberty: Between Anarchy and Leviathan, Cambridge University Press, 1980; Buchanan and Tollison (Eds). Theory of public choice: Political application of economics. The University of Michigan Press, Ann Arbor, 1972.; Vid. Mercado Pacheco, P. Op. cit., pp. 80 y ss. 
En el plano de la vida jurídica, y de acuerdo con la distinción de J.M. Keynes (El ámbito y el método de la Economía Política, 1891), entre economía positiva y economía normativa, las tareas del Análisis Económico del Derecho se han desarrollado también en ese doble sentido, positivo o descriptivo (teórico) y normativo o preceptivo (práctico).

a) Desde la perspectiva teórica, la Teoría económica del Derecho, entendida como ciencia positiva o descriptiva (ésta es la posición de M. Friedman y R. Posner) ${ }^{189}$, tiene por objeto el estudio y la explicación, desde el punto de vista de la racionalidad económica, del funcionamiento real, efectivo del Derecho en la sociedad, estudiando especialmente los efectos económicos de las normas jurídicas (Teoría del impacto legal) en la realidad social, con el fin de posibilitar pronósticos válidos acerca de determinados fenómenos ${ }^{190}$. De modo más concreto serán tareas del Análisis Económico del Derecho, desde el punto de vista de la economía positiva o descriptiva:

1ํ. Explicar los conceptos y categorías de significación económica contenidos en el Derecho.

$2^{\text {o }}$. Verificar el grado de "eficiencia económica" (relación costes-beneficios) del funcionamiento efectivo del sistema jurídico.

$3^{o}$. Evaluar cuantitativamente (econometría, estadística y jurimetría), y en su caso predecir, los costes y efectos económicos del funcionamiento del Derecho (Teoría del impacto legal) ${ }^{191}$.

189 Cfr. Friedman, M. La Metodología de la Economía Positiva, en el vol. col. "Filosofía y Teoría Económica" (Camps, F. Hahn y M. Hollis), trad. esp. de L. Suárez. Ed. Fondo de Cultura Económica, México, 1986, pp. 41, 42 y ss., 47 y ss.; Polinsky, A.M. Introducción al Análisis Económico del Derecho, trad. esp. de J.M. Álvarez Flores, ed. Ariel, Barcelona, 1985, pp. 10 y ss. TORRES LóPEZ, J. Op. cit., pp. 38 y ss.; Corona, J. F. La racionalidad en el Análisis Económico, en el vol. col. "Análisis Económico del Derecho y de la Política", Ed. Fundación Alfredo Brañas, col. Derecho № 5, Santiago de Compostela, 1993, p. 36; Mercado PACHECO, P. Op. cit., pp. 45 y ss.

190 Mercado Pacheco, P. pp. 45 y ss., 47 y ss.

191 Cfr. Paz-Ares, C. Op. cit., pp. 610, 624 y ss. Mercado Pacheco, P. Op. cit., pp. 47 y ss.; Pastor Prieto, S. Sistema jurídico y Ciencias Sociales: Análisis 
Desde esta perspectiva positiva o descriptiva del análisis económico R. Posner ha tratado de explicar y defender la eficiencia, la racionalidad económica del Common Law $^{192}$.

b) Desde el punto de vista práctico la Teoría Económica del Derecho se configura como ciencia normativa o preceptiva que se ocupa, no tanto de analizar y explicar cómo es y cómo funciona el Derecho, como de diseñar cómo debería ser y funcionar. Desde esta perspectiva normativa o preceptiva, en la que se desenvuelven preferentemente los estudios de G. Calabresi ${ }^{193}$, la Teoría económico-jurídica se ocupa del estudio de "cómo debe ser el Derecho", en función del principio de "eficiencia económica"

Desde los supuestos de este enfoque del estudio del Derecho el análisis económico del mismo, en conexión con la Política jurídica, se ocuparía, entre otras tareas, de:

$1^{o}$. Aconsejar los medios más adecuados y eficientes para alcanzar los fines propuestos por el Derecho.

$2^{\circ}$. Estudio y diseño de los reformas que sea necesario introducir en el sistema jurídico con el fin de potenciar el grado de eficiencia de las instituciones.

3 ‥ Elaboración "racional del Derecho" (de nuevas instituciones y sistemas normativos) de acuerdo con el principio de "eficiencia económica"195, si bien G. Calabresi y los seguidores de la escuela reformista pondrán de relieve que la "eficiencia económica" no

Económico del Derecho y jurimetría. en el vol.col. "Derecho y Sociedad", Ed. Tirant lo Blanch, Valencia, 1998, pp. 275 y ss, 279 y ss.

192 Mercado Pacheco, P. Op. cit., pp. 49 y ss.

193 Entre ellos cabe destacar, El coste de los accidentes. Análisis Económico y jurídico de la responsabilidad civil, trad. esp. Ariel, Barcelona, 1981. Cfr. MerCADO PACHECO, P. Op. cit., pp. 45 y ss. 54 y ss.;

${ }^{194}$ Cfr. Friedman, M. Op. cit., p. 41.; POLINSKY, A.M. Op. cit., pp. 10 y ss.; TORRES LÓPEZ, J. Op. cit., pp. 40 y ss.

195 Cfr. PaZ-ARes, C. Op. cit., pp. 611 y ss., 620 a 625, 694 y ss.; SCHÄFER, H. B. у Отт, C. Op. cit., pp. 219 y ss. y 353; DuRAn y la LaGuna, P. Una aproximación al Análisis Económico del Derecho. Ed. Comares, Granada, 1992, pp. 137 y ss.; Mercado Pacheco, P. Op. cit., pp. 35 y ss. y 61; Pastor Prieto, S. Sistema jurídico y economía..., cit., p. 30; Sistema jurídico y Ciencias Sociales..., cit., pp. $276,279,287$ y ss. 
es el único valor social y que, en determinados supuestos, deberá ceder ante las exigencias de otros valores $^{196}$.

El Análisis Económico del Derecho, concebido en los términos expuestos, ha encontrado un fecundo campo de aplicación en el ámbito del Derecho privado patrimonial (Civil y Mercantil), aunque nada impide su extensión a otras áreas, tanto del Derecho privado (del Derecho de familia, por ejemplo, donde sobresalen los trabajos de G. Becker ${ }^{197}$ ), como del Derecho público. En este sentido cabe destacar la importancia que el principio de "eficiencia económica" (aunque no sea el único ni el supremo criterio a tener en cuenta), tiene en el buen funcionamiento de las instituciones públicas, tanto políticas como administrativas, así como las nuevas perspectivas que el Análisis Económico del Derecho puede abrir en los ámbitos del Derecho Constitucional, del Derecho Administrativo (organización administrativa y servicios públicos), del Derecho sancionador (Penal y Administrativo), del Derecho Procesal (organización y funcionamiento eficiente de los tribunales de justicia), consideración por parte de los jueces del coste económico de sus decisiones... etc. ${ }^{198}$.

\section{C) Resultados}

Consecuencias del estudio y tratamiento del Derecho en función de los principios y categorías metodológicas de la Teoría económica son, entre otras:

196 Mercado Pacheco, P. Op. cit., pp. 54 y ss. y 61.

197 Tratado sobre la familia, trad. esp. Alianza Editorial, Madrid, 1987; CABRILlo, F. Análisis Económico del Derecho de familia, en el vol. col. "Análisis Económico del Derecho y de la Política", cit., pp. 67 y ss. Cfr. también MERCADO PACHECO, P. Op. cit., pp. 84 y ss.

198 Cfr. CASAs Pardo, J. Análisis Económico de las instituciones y de las reglas, en el vol.col. "Análisis Económico del Derecho y de la Política", cit., pp. 17 y ss.; PAStor Prieto, S. Sistema jurídico y economía..., cit., p. 31; Sistema jurídico y Ciencias Sociales..., cit., pp. 278 y ss. Mercado Pacheco, P. Op. cit., pp. 145, 221 y ss., 208,227 y ss., 271 y ss. 
a) Reducción del Derecho a regla técnica

Resultado inmediato del Análisis Económico del Derecho es una transformación o cambio en el modo de entender la naturaleza, la función y el criterio de legitimación del Derecho.

Desde los supuestos del Análisis Económico del Derecho, éste se constituye como un sistema de reglas técnicas al servicio de la eficiencia económica (satisfacción del mayor número de intereses o necesidades con el menor coste ${ }^{199}$. El Derecho se configura así como un instrumento técnico de control social (como una "tecnología" o "ingeniería social"). Ello tiene una serie de consecuencias de orden tanto teórico como práctico. Entre ellas cabe destacar:

1․ El abandono de la teoría imperativa del Derecho (Teoría imperativa de la norma), que es desplazada y sustituida por una “teoría incitativa del Derecho". Según ésta, el Derecho consiste en un mero "sistema de incentivos y rémoras": de incentivos, para influir positivamente (alentar) determinado tipo de conductas; de rémoras, para incidir negativamente (disuadir) en la realización de otros comportamientos ${ }^{200}$. Este cambio de enfoque en la consideración del Derecho supone prescindir del estudio del factor causante o generador del mismo y del tema de la naturaleza de sus normas - asunto central de la Filosofía del Derecho (la Ley, la norma como exposición de la voluntad de Dios, del hombre, del Estado...) - para centrar la atención en la investigación, desde el punto de vista de la eficiencia económica, de las relaciones existentes entre las normas jurídicas, los comportamientos humanos y sus resulta$\operatorname{dos}^{201}$, lo cual no constituye ya un tema filosófico sino socioeconómico.

$2^{\mathbf{o}}$. El Derecho, al configurarse como un sistema de reglas técnicas (incentivos y rémoras) al servicio de la eficiencia económica, aparece desprovisto de toda función

199 Mercado Pacheco, P. Op. cit., pp. 265 y ss.

200 Ibíd. Op. cit., pp. 39 y ss, 250,256 y ss.

${ }^{201}$ Ibíd. p. 265. 
paidética y de toda significación ética ${ }^{202}$, lo cual implica, en el fondo, una transformación en la naturaleza y significación de categorías fundamentales del pensamiento jurídico, tales como, por ejemplo, las de deber u obligación jurídica, acto ilícito, sanción jurídica, etc. En efecto, desde el punto de vista de la "racionalidad económica", el deber de obedecer a la Ley y la obligación de cumplir los contratos pierden toda significación ético-jurídica (la que les comunica el constituir exigencias de la justicia legal y de la justicia conmutativa) para quedar reducidos a la condición de una mera estrategia o cálculo económico (idea de "coste oportunidad"), según la cual la desobediencia a la Ley y el incumplimiento de los contratos podría ser lo "más racional" cuando ello suponga una maximización del bienestar del sujeto; esto es, cuando el pago de la sanción o la indemnización del daño producido por el incumplimiento de la obligación sean, desde el punto de vista económico, más ventajosos que la observancia de la Ley o el cumplimiento del contrato ${ }^{203}$.

Desde la perspectiva propia del Análisis Económico del Derecho cambia también de significado y función la institución de la pena, la cual pasa a ser considerada como el "precio social" que el delincuente debe pagar por el "bien" que para él supone la comisión del delito. La pena deja de ser así un instrumento para la reeducación o rehabilitación del delincuente, convirtiéndose en un simple medio de prevención y disuasión de la delincuencia, en la medida en que suponga un precio tan alto que no compense de la comisión del delito ${ }^{204}$.

$3^{o}$. Convertido el Derecho en una tecnología al servicio de la economía el criterio de legitimación del mismo - al margen de vagas y retóricas invocaciones a la justicia y a la equidad- se desplaza del plano ético al plano económico, cuyo criterio supremo de racionalidad y validez se cifra en la "eficiencia económica" o "maximización de la rique-

202 Ibíd. pp. 255 y ss.

${ }^{203}$ Ibíd. pp. 42 y ss.

${ }^{204}$ Ibíd. pp. 41 y ss., 47 y 48, nota 34 y 228. 
za". Así acontece, al menos, en el pensamiento conservador de la escuela de Chicago, con R. Posner y sus seguidores. El principio de eficiencia económica (máxima eficacia con el mínimo coste) implica la reducción de todo problema jurídico a términos de racionalidad económica; a un problema económico de cálculo y ponderación de costes y beneficios $^{205}$, en el curso del cual los valores y las exigencias éticas suelen ceder y sacrificarse con frecuencia a los intereses económicos.

Tal cosa no debe extrañarnos si pensamos el papel determinante que en ello juega la formación y mentalidad de signo fundamentalmente económico (más económico que ético y jurídico) de quienes se han aplicado a este tipo de estudios.

\section{b) Funciones del Derecho}

Reducido el Derecho a la condición de mero instrumento técnico al servicio de la eficiencia económica (con la consiguiente inercia a dar prioridad al tratamiento y solución de los problemas económicos, y a la protección de los bienes de dicha naturaleza) ${ }^{206}$, sus funciones se dirigen preferentemente -mediante el empleo de técnicas de promoción y disuasión- a estimular los comportamientos sociales relativos a la distribución de recursos que maximicen el valor total de la riqueza (asignación más eficiente de recursos). Ello se alcanza, según R. Posner, cuando en el curso del proceso de cambio voluntario de recursos, estos llegan a aquellos usos en los que su valor es máximo porque, a partir de ahí, ya nadie pagará más por disponer de dichos recursos ${ }^{207}$.

El Derecho contribuye a la estimulación de los comportamientos sociales que hacen posible la más eficiente dis-

205 Durán y la Laguna, P. Op. cit., pp. 83, 138 y ss., 143 y ss., 145 y ss., 147 y ss., 190, 195, 205 y 207; Mercado PaCheco, P. pp. 36, 38, 57, 223, 267 y ss.

${ }^{206}$ DuRÁn y la Laguna, P. Op. cit., pp. 183 y ss.

207 Cfr. PAZ-AREs, C. Op. cit., pp. 626 y ss. 630 a 639 y 696. Véanse también las pp. 640 y ss. 682 y ss.; SCHÄFER, H. B. y OTt, C. Op. cit., pp. 24 y ss.; MerCADO PACHECO, P. Op. cit., pp. 39 a 44 y 223. 
tribución de recursos económicos, de un lado, poniendo a disposición de la vida económica un conjunto de instituciones específicamente jurídicas; de otro lado, desplegando una serie de funciones en relación con la situación del mercado. Veamos, por separado, esa doble contribución:

1‥ Las instituciones jurídicas de las que se sirve el Derecho para la más eficiente distribución de los recursos en el mercado son las constituidas por la propiedad (asignación y distribución de recursos), el contrato (instrumento clave de la libertad de mercado que permite el libre intercambio de recursos), y, en el supuesto de accidentes, la responsabilidad civil extracontractual (aquí entran en juego principios que, sustituyendo las operaciones de mercado imputan la responsabilidad a la solución económicamente más eficiente $)^{208}$. En este último supuesto, estudiado especialmente por G. Calabresi, destacan también los trabajos de R. Coase, R. Posner, J. P. Brown, P. Diamond y otros ${ }^{209}$.

En relación con el problema de la responsabilidad civil extracontractual, un ejemplo ilustrativo de la reducción del problema jurídico a un problema económico — según la metodología del Análisis Económico del Derecho- lo encontramos en la tesis del juez L. Hand. Según ésta, el hipotético agente de un daño será culpable de negligencia si el coste de los daños causados por el accidente multiplicados por la probabilidad de que el accidente ocurra, excede del coste de las precauciones que dicho agente podría haber adoptado para impedir la producción del siniestro ${ }^{210}$.

${ }^{208}$ Cfr. PAZ-ARes, C. Op. cit., pp. 629 y ss., 642 y 646,654 y ss., 664 y ss., 682 y ss.; SCHÄFER, H. B. у ОTт, C. pp. 82 y ss., 98 y ss., 107 y ss., 148 y ss., 219 y ss., 258 y ss., 261 y ss.; Duran y la Laguna, P. Op. cit., pp. 121 y ss., 198 y 203 a 209; PASTOR PRIETO, S. Sistema jurídico y economía..., cit., pp. 135 y ss., 148 y ss., 155 y ss.; Sistema jurídico y Ciencias Sociales..., cit., pp. 277 y ss. Gómez Pomar, F. El Derecho de accidentes y el Análisis Económico: Presupuestos e implicaciones básicas, en el vol. col. "Análisis Económico del Derecho y de la Política". cit., pp. 83 y ss.; Mercado Pacheco, P. Op. cit., pp. 37 y ss., 43, 59 y ss. 144, 147 y ss., 151 y ss., 235 y ss., 238 y ss., 240 y ss.

${ }^{209}$ Gómez Pomar, F. Op. cit., pp. 89 y ss.; Mercado Pacheco, P. Op. cit., pp. 28 y ss.

210 Mercado Pacheco, P. Op. cit., p. 270. Véanse también la posición de P. Schlag, siguiendo a R. H. COASE, ibíd. pp. 217 y ss. 
Debemos advertir, además, que desde los supuestos del Análisis Económico del Derecho cambia también la función que tradicionalmente se había asignado a la responsabilidad civil. Ahora la función primordial de la responsabilidad civil no es tanto la compensación o reparación del daño producido como la prevención del daños futuros ${ }^{211}$.

Junto a las instituciones de la propiedad, el contrato, y la responsabilidad civil extracontractual, el Derecho contribuye también a la más eficiente distribución de los recursos económicos con el sistema normativo del Derecho Penal, al que corresponde, a este respecto, la cobertura y garantía del libre funcionamiento del mercado negocial privado, sancionando las conductas delictivas contrarias al mismo ${ }^{212}$.

$2^{\mathbf{o}}$. En la tarea de estimular la distribución de recursos que maximicen el valor total de la riqueza corresponden al Derecho una serie de funciones que, en cada caso, aparecen condicionadas, según el teorema de R. Coase, por la situación del mercado. A este respecto cabe distinguir los siguientes supuestos:

a) Si el mercado se encuentra en equilibrio perfecto (óptimo de Pareto), el Derecho deberá limitarse a asegurar las condiciones de libertad y seguridad del mismo.

b) Cuando el equilibrio del mercado no surge de modo natural corresponderá al Derecho llevar a cabo una función correctiva de ajuste entre la divergencia del coste y el beneficio social.

c) Por último, cuando la recuperación del equilibrio del mercado sea imposible, será tarea del Derecho (que operará aquí como un mercado simulado), asignar costes y beneficios a las partes, tal como lo hubiera hecho el mercado, si no hubiesen mediado costes de transacción prohibitivos ${ }^{213}$.

${ }^{211}$ Mercado Pacheco, P. Op. cit., pp. 226 y ss.

${ }^{212}$ Ibíd, pp. 38, 237 y ss.

${ }^{213}$ Duran y la Laguna, P. Op. cit., pp. 84, 85 y 198; Pastor Prieto, S. Sistema jurídico y economía..., cit., pp. 120 y ss.; MerCADo PaCheco, P. Op. cit., 27 y ss., 37, 61, 128 y ss., 130, 134 y ss., 137 y ss., 139 a 146, 150 y ss. 


\section{D) Consideraciones críticas}

En cuanto concepción epistemiológica y metodológica el Análisis Económico del Derecho tiene su cara y cruz, sus aspectos positivos y negativos.

\section{a) Aspectos positivos}

La cara o aspecto positivo del Análisis Económico del Derecho consiste en su virtualidad para poner de relieve y llamar la atención sobre una serie de cuestiones y problemas que, dentro de la economía total de la mejor ordenación y racionalización de la vida social, el Derecho ha de conocer y tomar en consideración. Y ha de hacerlo porque ello afecta de modo inmediato a la estructura, funcionamiento y eficacia de organismos e instituciones del sistema jurídico, tanto privado como público. En este sentido parece que el Análisis Económico del Derecho podría dar óptimos resultados tanto en su aplicación al estudio de la vida negocial privada como de la política y la administración pública. En este ámbito podría contribuir decididamente al saneamiento, reajuste, simplificación y potenciación de la funcionalidad y eficiencia del aparato institucional (político y administrativo) de la estructura del Estado.

\section{b) Aspectos negativos}

La cruz o aspecto negativo del Análisis Económico del Derecho viene constituido por el "reduccionismo economicista" que implican los supuestos y la finalidad misma a la que se orienta dicho estudio, al tratar de comprender, explicar y valorar la estructura y funcionamiento de la sociedad y del Derecho en función de las categorías propias de la Teoría económica y, de modo especial, de acuerdo con las exigencias del principio de "eficiencia económica".

Ese "reduccionismo económico" tiene una serie de consecuencias negativas, entre las que deben destacarse:

1․ En primer lugar, proporciona una visión distorsionada de la realidad social y de las instituciones jurídicas 
cuya naturaleza y función no es —o no lo es de modo primordial- de carácter económico o mercantil ${ }^{214}$.

2ºn segundo lugar, el Análisis Económico del Derecho nos ofrece una visión unilateral e insuficiente del mismo, al reducir el sistema jurídico a un mero instrumento técnico, a una "ingeniería social", cuya función es la transformación de todo problema o conflicto jurídico en un problema económico de cálculo y ajuste de costes y beneficios, y asignación eficiente de recursos escasos ${ }^{215}$. Hemos de insistir en que los puntos de vista, los criterios de valoración y los métodos específicos del Análisis Económico del Derecho resultan, en sí mismos - por la inercia propia de las formas y los métodos del pensamiento económico, y aunque se hagan invocaciones bienintencionadas a las exigencias de la justicia y la equidad - insuficientes e inadecuados para comprender en su plenitud el significado y la función que corresponde al Derecho en la ordenación de la vida social. Esta afirmación exige algunas aclaraciones que estudiaremos separadamente:

\section{c) Primera aclaración}

La citada insuficiencia e inadecuación encuentra uno de sus fundamentos esenciales en el fenómeno de la reducción del Derecho (que es norma ética) a la condición de mera regla técnica. Desde el punto de vista de la Filosofía del Derecho esa transmutación implica una serie de consecuencias que, de modo sucinto, podemos esquematizar en los siguientes términos:

1‥ Desplazamiento y sustitución de la idea de fin del Derecho por la idea de función.

La idea de fin en el Derecho tiene una significación ético-material (aparece referida, fundamentalmente

214 Mercado Pacheco, P. Op. cit., pp. 99 y ss., 257 y ss.

${ }^{215}$ Ibíd. pp. 145, 223 y ss. 
al valor de la justicia) que apunta directamente al qué o al para qué del Derecho. La noción de función, no tiene "per se" una significación material, sino formal y técnica; no hace referencia al qué sino al cómo (dirección de conductas, organización y distribución de tareas y bienes, solución de conflictos, etc.). Esto es, la idea de función aparece referida a la forma o modo de operar el Derecho en la vida social, desentendiéndose de los fines o valores a los que debe servir.

2. Desplazamiento y sustitución de la idea de validez jurídica por la de eficacia.

La idea de validez posee una connotación éticomaterial e incluso ideológico-política que aparece referida tanto al contenido de la norma (legitimidad de lo que la norma prescribe), como al órgano que la ha dictado (competencia o legitimidad del órgano para dictar normas) y a la corrección o formalidad del procedimiento seguido en la elaboración de la misma. Frente a las aludidas connotaciones (ético-materiales e ideológico-políticas), de la idea de validez jurídica, la idea de eficacia posee una significación "neutral", técnica y fáctica que se adecua mejor a las exigencias epistemiológicas y metodológicas del objeto de las ciencias empíricas o positivas.

3‥ Desplazamiento y sustitución del conocimiento filosófico del Derecho por el sociológico-jurídico.

Consecuencia lógica del desplazamiento de la idea de fin del Derecho por la de función, y de la idea de validez jurídica por la de eficacia, es el desplazamiento y la sustitución de la Filosofía del Derecho por la Sociología jurídica. El resultado de ello es una visión insuficiente, por incompleta y parcial, del fenómeno jurídico, al quedar reducido el Derecho a un mero hecho, a un instrumento técnico de organización y control social, sin más criterio de valoración que el de su eficiencia o eficacia. 
d) Segunda aclaración

Pasando de lo general y abstracto a lo más concreto nos encontramos con manifestaciones evidentes de la insuficiencia e inadecuación del Análisis Económico del Derecho respecto de la comprensión y estudio del significado y la función que corresponde al mismo en la ordenación de la vida social. Ello suele ponerse de manifiesto en aquellos supuestos en que entran en conflicto el principio de eficiencia económica y otros valores éticos y sociales (justicia, equidad, seguridad, solidaridad, etc.) que pertenecen a la entraña misma del Derecho y que constituyen parte integrante de la noción de bienestar social, de bien común. En estos casos, y desde la perspectiva eminentemente técnica del Análisis Económico del Derecho, se tiende a primar la eficiencia ${ }^{216}$. Así, acontece en el pensamiento de la corriente mayoritaria del Análisis Económico del Derecho y, especialmente, en R. Posner, quien identifica la justicia con el valor de la eficiencia entendida como maximización de la riqueza $^{217}$. Sin embargo, no faltan autores como G. Calabresi y otros (A. M. Polinsky, B. A. Ackerman...) que se abren a otros criterios buscando la armonía o compromiso entre eficiencia y justicia ${ }^{218}$.

Uno de los campos en donde el conflicto entre la justicia y el principio de eficiencia económica alcanza un grado de tensión altamente dramático es el ámbito del Derecho sancionador (penal y administrativo), en donde se debate el tema de la "sanción óptima" 219 . En esta materia algunos autores han diseñado planteamientos puramente economicistas (en términos de costes y beneficios) de la sanción y, por ello, insuficientes e injustos en muchos casos. La gravedad y el dramatismo del tema se pone de relieve cuando, en el proyecto de un sistema penitencia-

216 PAStor Prieto, S. Sistema jurídico y economía..., cit., pp. 34 y ss., 40 y ss. Duran y la Laguna, P. Op. cit., pp.144 y ss., 190, 195 y ss.

${ }^{217}$ Mercado Pacheco, P. Op. cit., pp. 278 y ss.

218 Ibíd. pp. 57 y ss., 279 y ss.

219 Pastor Prieto, S. Sistema jurídico y Ciencias Sociales..., cit., p. 278; Sistema jurídico y economía..., cit., pp. 167 y ss., 170 y ss., 205. 
rio, y desde los supuestos del principio de eficiencia económica, hay que elegir, por ejemplo, entre la financiación de los elevados costes que parece suponer el mantenimiento en prisión durante largo tiempo de delincuentes muy peligrosos o su eliminación mediante la aplicación de la pena capital ${ }^{220}$.

La solución justa, eficaz y, en último término, humana de estos conflictos exige una prudente tarea de mediar y armonizar principios y valores encontrados ${ }^{221}$, para la cual resulta insuficiente e inadecuado el planteamiento economicista que atiende el Derecho como un sistema de reglas técnicas al servicio de la eficiencia económica. El adecuado planteamiento y solución de dichos conflictos exige previamente ver en los mismos, no un problema puramente técnico sino, fundamentalmente, un problema ético. La solución de dicho problema precisa, entre otras cosas, el abandono de la concepción del Derecho como un mero instrumento técnico de control social, y la recuperación de la noción del Derecho como sistema de normas éticas al servicio de unos fines éticos-sociales, al que corresponde, como función parcial de su tarea ordenadora e integradora de la vida social, el desarrollo de una ineludible función educadora del ciudadano.

\section{CONSIDERACIONES CRÍTICAS}

La reducción del Derecho a regla técnica, la configuración del Derecho como un aparato técnico de ordenación y control social, supone una alteración, una subversión de los principios y valores que tradicionalmente han inspirado la teoría y la práxis jurídica.

En este orden de cosas tenemos:

${ }^{220}$ Duran y la Laguna, P. Op. cit., pp.99 y ss., 207 y ss.

${ }^{221}$ Cfr. PaZ-ARes, C. Op. cit., pp. 690 y ss., 696 y ss. 701 y ss.; PolinskY, A.M. Op. cit., pp. 123 y ss.; SCHÄFER, H. B. Y ОTт, C. Op. cit., pp. 17 a 19, 25 y ss.; ToRRES LóPez, J. Op. cit., pp. 90 y 95; PASTOR PRIETO, S. Sistema jurídico y economía..., cit., p. 40; MerCAdo PACHECO, P. Op. cit., pp. 57 y ss., 279 y ss. 


\section{1. Ámbito del conocimiento teórico del Derecho}

El primado del valor de la utilidad y la reducción del Derecho a mera técnica, que es sólo una dimensión constitutiva del mismo, provoca, en primer lugar, una alteración, una subversión en el ámbito del conocimiento jurídico que se manifiesta, fundamentalmente, de dos formas:

\section{A) Una concepción insuficiente del Derecho}

Desde los supuestos indicados la teoría del Derecho sólo ha podido obtener una concepción parcial, incompleta, insuficiente del Derecho en la que éste, de una u otra forma, aparece referido, cuando no identificado, con la fuerza. Se trata, en el fondo, de una subversión axiológica y conceptual que, fundada en el primado de la utilidad y la eficacia, confunde y altera la jerarquía entre fines y medios. De ahí que, en relación con el Derecho, la justicia sea entendida como algo ajeno, extraño, al mismo (H. Kelsen) o aparezca distorsionada y reducida a una categoría puramente formal que se identifica en la mera legalidad (justo es lo legal, lo prescrito por el Derecho positivo), con el adecuado grado de complejidad del sistema social (N. Luhmann) o con el valor máximo de la eficiencia entendida como "maximización" de la riqueza (R. Posner).

\section{B) Confusión y subversión en el estatuto y temática de la Filosofía del Derecho}

El destierro de la ética en la reflexión jurídica y el primado de la técnica y la eficacia en la concepción del Derecho y de su praxis origina una confusión y subversión radical en la concepción del fin y de la temática de la Filosofía del Derecho.

A este respecto cabe recordar sumariamente, y a modo de conclusión general, algo que ya se ha indicado:

a) El desplazamiento de la idea de fin (o fines) del Derecho (que tiene una significación axiológica, ético-ma- 
terial) y su sustitución por la idea de función, que posee un carácter puramente instrumental, formal y técnico.

b) El desplazamiento de la idea de validez jurídica que hace referencia a la legitimidad (validez filosófica) y a la posibilidad o legalidad (validez dogmática) —como momentos diferenciados y necesarios en el proceso de génesis y constitución del Derecho- y su sustitución por la idea de eficacia, que posee una significación puramente fáctica, sociológica. Dicha idea constituye el último momento del proceso de realización y perfeccionamiento del Derecho pero, en cualquier caso, es algo independiente del fenómeno de la validez del Derecho como sistema normativo. La validez del Derecho, en principio, constituye una categoría independiente de su eficacia. La norma que ha sido infringida continua siendo válida y obliga a su cumplimiento. En caso contrario, habría que admitir que la infracción de una norma implica también su derogación.

c) El desplazamiento de la Filosofía del Derecho, en cuanto conocimiento del Derecho en su plenitud ontológica (ontología jurídica), y su sustitución por la Sociología del Derecho, ciencia puramente empírica atenta al estudio de las interconexiones del Derecho como hecho social con otros hechos o fenómenos de la vida social y, de modo especial, a la consideración y vicisitudes del Derecho como técnica de ordenación y control social.

\section{2. Ámbito de la práxis jurídica}

En el plano de los problemas concretos y de la aplicación práctica del Derecho la reducción de éste a un instrumento técnico al servicio de la ordenación y del control social implica una serie de complejas y plurales referencias del Derecho y otros temas, entre las que sólo vamos a tomar en consideración las relativas a las relaciones del Derecho con la axiología, con la fuerza y con las formas políticas. 


\section{A) Derecho y axiología}

La vida humana, tanto privada como pública, aparece en sus más diversos y plurales momentos $-\mathrm{y}$ sin ello no tendría sentido, perdiendo la dimensión de su humanidad- referida al mundo de los valores en sus diferentes especies o categorías (desde los meramente económicos o materiales a los espirituales). Esa referencia al mundo de los valores es la que eleva y confiere a la vida del hombre -que no es algo solamente biológico- la dimensión y la dignidad de la humanidad.

Por esta razón, las teorías filosóficas y filosófico-jurídicas que enfocan y valoran el Derecho y lo humano, de forma exclusiva, desde el punto de vista de la utilidad y de la técnica, mutilan la humanidad de los hombres, los deshumanizan y tienden a degradarlos, por barbarie o frivolidad, a la condición de "esclavos técnicos"222, a los que no sería lícito - dentro del orden social en que viven y más allá de lo que puedan disponer las reglas de esa maquinaria a la que queda reducido el Derecho- plantearse, preguntar y exigir (porque ello sería un "sin sentido") lo que ellos, en cuanto seres humanos, piensan, ven, creen y sienten como bueno y justo. Así sucede, por ejemplo, desde los supuestos del nihilismo del pensamiento jurídico escandinavo y de otros nihilismos (funcionalismo, economicismo...). Si se piensa que las ideas de deber, derecho subjetivo, responsabilidad jurídica, entre otras, no son más que una ilusión metafísica, un residuo del pensamiento mágico primitivo (Hägerström, Lundstedt, Olivecrona, etc.) que persiste como idea atávica en la mente humana, ¿qué sentido puede tener hablar de la dignidad de la persona y de los derechos del hombre?.

Cuando hablamos de la relación entre Derecho y axiología debe pensarse que utilidad y bondad, aunque ambas constituyan valores, pertenecen a planos o niveles diferentes del mundo axiológico. Debe pensarse también que

${ }^{222}$ Corts Grau, J. Cara y cruz de la Técnica, en el vol. "El hombre en vilo" (Ensayos). Prólogo de P. Laín Entralgo, Ed. Aguilar, Madrid, 1958, pp. 35 a 50. 
cuando invocamos nuestros derechos nos estamos refiriendo a algo distinto de nuestros meros intereses ${ }^{223}$.

\section{B) Derecho y fuerza}

La primacía, la obsesión por lo útil, induce, arrastra al "relativismo" y al "nihilismo ético", en donde todo gira en torno al "éxito" y a los "medios" más eficaces y directos para alcanzarlo. Ello tiene, por lo pronto, dos consecuencias:

a) De un lado, la acuñación de "un nuevo tipo humano": el tipo humano del ganador, como modelo opuesto al del "perdedor". Se trata de un nuevo ejemplar de "hombre masa" que sólo se aclimata a vivir en el mar revuelto y cruel donde viven los tiburones del egoísmo y la ambición. Se trata de un tipo ¿humano? que sólo busca la riqueza, el poder, el lujo y el placer y para el que no cuentan nada los valores de la cultura ni los éticos del amor y de la compasión, de la amistad y del honor en su más alto y noble sentido, y cuya acción no reconoce ni respeta otras referencias y límites que los constituidos por el éxito (ganar) y el fracaso (perder). El binomio ganador-perdedor ha penetrado la mentalidad de la sociedad actual, de nuestra actual "cultura", como ahora se dice, reflejándose en los triviales juicios de valor de que dicha sociedad es capaz y en su insulso lenguaje que se deja oír en la calle, en la televisión e incluso en el cine. Ello ha cristalizado en la idolatría del "ganador" o "triunfador" y en el desprecio del "perdedor". No hay compasión para el que pierde.

b) De otro lado, y en conexión con lo anterior, la segunda consecuencia es la exaltación de la fuerza, (física, económica, política...) como medio de alcanzar, a cualquier precio y de cualquier modo, el "éxito", el triunfo y que no reconoce más frenos y límites que los impuestos por el fracaso (perder).

${ }^{223}$ Corts Grau, J. Curso de Derecho natural, $2^{\text {a }}$. Ed. Editora Nacional, Madrid, 1959, pp. 79 y 80 . 
El "relativismo, el nihilismo ético" incluso, que subyace a la concepción del Derecho como regla técnica, como aparato técnico para la ordenación y el control social, implica dos cosas:

1. La reducción del Derecho a una estructura técnicoformal que puede asumir como propio, como jurídico, cualquier contenido, con independencia del valor moral que nos merezca (Kelsen) ${ }^{224}$.

2. La conversión de la fuerza en el centro de gravedad del Derecho.

En cuanto medio de ordenación y control social el Derecho se haya indisolublemente unido a la fuerza. La fuerza, como coacción, se convierte en elemento esencial, constitutivo del Derecho.

En este contexto la conexión Derecho-fuerza ha encontrado múltiples formulaciones susceptibles de reducción a algunas de las posibilidades siguientes:

$1^{\circ}$. La fuerza o coacción como garantía de la eficacia del Derecho (R. von Ihering).

$2^{2}$. La fuerza o coacción como objeto del Derecho. Este no es más que un sistema de reglas técnicas que tienen por objeto la regulación del uso de la fuerza, ejercida, en régimen de monopolio, por el Estado (K. Olivecrona, A. Ross).

$3^{3}$. La fuerza o coacción como contenido del Derecho. Ello supone la identificación entre Derecho y fuerza al ser concebido el Derecho como un sistema de normas coactivas (H. Kelsen) ${ }^{225}$.

\section{C) Derecho y formas políticas}

El "relativismo y nihilismo axiológicos" de las doctrinas estudiadas, la reducción del Derecho a mera técnica de ordenación y control social mediante el ejercicio de la

${ }^{224}$ Kelsen, H. Teoría general del Derecho y del Estado, cit., p. 133.

${ }^{225}$ PÉrez Luño, A.E. Teoría del Derecho, cit., pp. 159 y 160. 
fuerza supone, en el plano político, la disolución y desplazamiento de la doctrina clásica de las formas de gobierno que se ha venido desarrollando en la cultura occidental desde Platón hasta nuestros días. Dicha doctrina, que distingue entre formas de gobierno justas e injustas, en función, en cada caso, del origen del poder y de la forma de su ejercicio, es desplazada y sustituida por una nueva teoría política en donde se integran y complementan recíprocamente el hedonismo social (satisfacción de las apetencias que sólo tienen como finalidad la abundancia, el lujo y el placer, - cosas que, en realidad, sólo podría alcanzar una parte de la sociedad-), el politicismo (la política entendida como técnica al servicio de la conquista y conservación del poder por cualquier medio - virtù en el sentido de Maquiavelo-) y el economicismo (abundancia y enriquecimiento mediante la producción y acumulación de bienes a través del intercambio de ellos en el libre mercado) ${ }^{226}$.

La nueva forma política que de ahí resulta es exaltada no por su justicia sino por su alto grado de eficacia en función de su utilidad social (prestación de servicios, creación de riqueza), de su fuerza política (Estado autocrático e incluso totalitario) o de su eficiencia económica, tal como postulan doctrinas como la del Análisis económico del Derecho y, en general, las tesis que ven en el capitalismo, sin más, la clave para la solución de todos los problemas.

En este esquema encajan perfectamente las teorías funcionalistas, como la de G. Jakobs, según la cual cualquier sistema social existente, por el simple hecho de existir - ya sea una sociedad instrumental (sociedad esclavista) o una sociedad no instrumental (sociedad de hombre libres)_ por el mero hecho de su existencia —insistimos-, es válido y debe ser protegido por el Derecho ${ }^{227}$.

${ }^{226}$ Ballesteros, J. Sobre el sentido del Derecho, (Introducción a la Filosofía jurídica), $3^{\underline{a}}$ ed. Ed. Tecnos, Madrid, 2001, pp. 31 y ss, 38 y ss.

${ }^{227}$ JАKOBS, G. Op. cit., pp. 20 a 22,37 у 38. 
3. Necesidad y urgencia de reenquiciar las relaciones entre ética y técnica en el Derecho

Ante este estado de cosas parece necesario y urgente reenquiciar el planteamiento y estudio de las relaciones entre ética y técnica en el Derecho. El sentido de este reenquiciamiento no puede ser otro que el de buscar, concretar y fijar la significación y los límites de la ética y la técnica en el Derecho de acuerdo con la natural relación que debe existir entre fines y medios.

La ética supone, ante todo, valores, fines, y es incapaz por sí misma, sin el concurso de la técnica, de definir, encauzar y garantizar el orden de la vida social.

La técnica, por sí sola, en su condición natural de medio, de instrumento para hacer algo, sin la iluminación, los límites y el control de la ética degenera en un puro fenómeno de fuerza (fuerza social, política y/o económica) capaz sólo de articular y vertebrar una sociedad instrumental, deshumanizada, en la que las personas son degradadas a la condición de cosas.

En relación con el orden de la vida social, ética y técnica adquieren su más alta significación humanista en cuanto se consideran como dimensiones constitutivas del Derecho. La ética, como dimensión material, hace referencia a los principios y valores que inspiran y nutren los fines últimos del Derecho. La técnica, en cuanto dimensión formal e instrumental del Derecho, constituye el medio que permite, hace posible y garantiza la realización de los fines supremos del Derecho. El Derecho, en cuanto fenómeno histórico cultural, es una realidad en donde ética y técnica, como dimensiones constitutivas del mismo, se articulan, complementan, limitan e integran, como partes de un todo unitario e indivisible, con el fin de crear un orden de vida social, justo, estable y seguro, verdaderamente humano. 